\title{
Explorations of pelvic floor ultrasound
}

Citation for published version (APA):

Weemhoff, M. (2013). Explorations of pelvic floor ultrasound. [Doctoral Thesis, Maastricht University]. Universitaire Pers Maastricht. https://doi.org/10.26481/dis.20130705mw

Document status and date:

Published: 01/01/2013

DOI:

10.26481/dis.20130705mw

Document Version:

Publisher's PDF, also known as Version of record

\section{Please check the document version of this publication:}

- A submitted manuscript is the version of the article upon submission and before peer-review. There can be important differences between the submitted version and the official published version of record.

People interested in the research are advised to contact the author for the final version of the publication, or visit the DOI to the publisher's website.

- The final author version and the galley proof are versions of the publication after peer review.

- The final published version features the final layout of the paper including the volume, issue and page numbers.

Link to publication

\footnotetext{
General rights rights.

- You may freely distribute the URL identifying the publication in the public portal. please follow below link for the End User Agreement:

www.umlib.nl/taverne-license

Take down policy

If you believe that this document breaches copyright please contact us at:

repository@maastrichtuniversity.nl

providing details and we will investigate your claim.
}

Copyright and moral rights for the publications made accessible in the public portal are retained by the authors and/or other copyright owners and it is a condition of accessing publications that users recognise and abide by the legal requirements associated with these

- Users may download and print one copy of any publication from the public portal for the purpose of private study or research.

- You may not further distribute the material or use it for any profit-making activity or commercial gain

If the publication is distributed under the terms of Article $25 \mathrm{fa}$ of the Dutch Copyright Act, indicated by the "Taverne" license above, 
Explorations of Pelvic Floor Ultrasound 
CCopyright 2013 Mirjam Weemhoff

All rights reserved. No part of this publication may be reproduced, stored in retrieval system, or transmitted, in any form or by any means, without the permission from the copyright owner.

Layout: Tiny Wouters

Production: Datawyse / Universitaire Pers

ISBN 9789461592323 


\section{Explorations of Pelvic Floor Ultrasound}

\section{PROEFSCHRIFT}

ter verkrijging van de graad van doctor

aan de Universiteit Maastricht,

op gezag van de Rector Magnificus, Prof. dr. L.L.G. Soete,

volgens het besluit van het College van Decanen,

in het openbaar te verdedigen

op vrijdag 5 juli 2013 om 12.00 uur

door

Mirjam Weemhoff

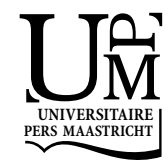




\section{Promotores}

Prof. dr. J.L.H. Evers

Prof. dr. R.F.P.M. Kruitwagen

\section{Copromotor}

Dr. K.B. Kluivers (Universitair Medisch Centrum St Radboud, Nijmegen)

\section{Beoordelingscommissie}

Prof. dr. R.G.H. Tan-Beets (voorzitter)

Dr. G.A. van Koeveringe

Dr. J.P.W.R. Roovers (Academisch Medisch Centrum, Amsterdam)

Prof. dr. L.P.S. Stassen

Prof. dr. M.E. Vierhout (Universitair Medisch Centrum St Radboud, Nijmegen) 


\section{Contents}

Abbreviations

Chapter 1 Introduction

Chapter 2 Postoperative catheterization after anterior colporrhaphy:

2 versus 5 days. A multicentre randomized controlled trial

Int Urogynecol J 2011;22:477-483

Chapter 3 Avulsion of puborectalis muscle and other risk factors for

cystocele recurrence: a 2 year follow up study

Int Urogynecol J 2012;23:65-71

Chapter 4 Transperineal ultrasound compared to evacuation proctography for diagnosing enteroceles and intussusceptions

Int J Colorectal Dis 2013;28:359-363

Chapter 5 Optimizing the image quality of pelvic floor ultrasound

Submitted

Chapter 6 Comparison of two scoring systems for diagnosing levator ani muscle damage

Int Urogynecol J. 2013

Chapter 7 General discussion

Summary / Samenvatting

List of publications

Curriculum Vitae

Dankwoord 



\section{Abbreviations}

2D

Two dimensional

3D Three dimensional

4D Four dimensional

AUC Area under the Curve

BMI Body Mass Index

$\mathrm{Cl} \quad$ Confidence Interval

ICS International Continence Society

LR- $\quad$ Negative Likelihood Ratio

LR+ Positive Likelihood Ratio

LUG Levator Urethal Gap

MRI Magnetic Resonance Imaging

$\mathrm{N} \quad$ Number of patients

NPP Negative Predictive Value

OR Odds Ratio

$\mathrm{p} \quad$ Value of significance

POP Pelvic Organ Prolapse

POPQ Pelvic Organ Prolapse Quantification System

PPV Positive Predictive Value

PREV Prevalence

ROC Receiver Operating Curve

SD Standard Deviation

SENS Sensitivity

SPEC Specificity 

Chapter 1

Introduction 
Chapter 1 


\section{Introduction}

In view of the high prevalence of pelvic organ prolapse (POP) and the high recurrence rate after surgery for POP, there is a need for better (preoperative) analysis of patients with POP. Better knowledge of risk factors for recurrent POP and understanding of the underlying causes may result in a more individually tailored and effective treatment. Imaging of the pelvic floor muscles with use of perineal ultrasound is one of the promising diagnostic tools which have been introduced in recent years.

\section{Pelvic organ prolapse}

Pelvic organ prolapse (POP) is a highly prevalent condition. POP is a downward descent of pelvic organs resulting in a protrusion of the vagina, uterus or both (1). There are different types of POP: anterior compartment prolapse (bladder and/or urethra), apical compartment prolapse (uterus or vaginal vault) and posterior compartment prolapse (rectum, sigmoid, small intestines). Abnormalities in one compartment are often accompanied with disorders in other compartments. The anterior compartment is most frequently affected (2). Some loss of vaginal support is present in most adult women. In the Women's Health Initiative, $41 \%$ of women age 50-79 years showed some POP (1).

\section{Risk factors pelvic organ prolapse}

The cause of POP is multifactorial (3). Most consistently reported risk factors are vaginal childbirth, advancing age and obesity. Other factors that have been associated with an increased risk of POP, albeit less consistently, include pregnancy (irrespective of mode of delivery), forceps delivery, prolonged second stage of labour, macrosomia, family history of POP, ethnic origin, occupations entailing heavy lifting, constipation, connective tissue disorders and previous hysterectomy (4).

Vaginal birth gives a 4 to 11 fold increase in risk for developing POP among parous women compared to women without vaginal delivery in their history (5). A levator defect is a detachment of the inferomedial aspects of the levator ani muscle from its insertion on the pelvic sidewall. In $20-23 \%$ of women who had delivered vaginally, trauma of the levator ani was identified (6). Studies with MRI and pelvic floor ultrasound have demonstrated that major levator defects are a risk factor for POP (7). Dietz found major levator defects to be also a risk factor for recurrence after POP surgery (8).

\section{Symptoms and physical examination}

To standardize clinical examination, the International Continence Society (ICS) recommends the use of the Pelvic Organ Prolapse Quantification system (POPQ)(9). 
This scoring system describes in centimeters the degree of anterior, apical and posterior vaginal wall descent in relation to the hymenal remnants, and classifies the support in five stages from 0 (perfect support) to IV (complete vaginal eversion). In terms of test characteristics (e.g. reliability), the POPQ is not perfect, but it is widely used among urogynecologists worldwide and makes anatomical outcomes of scientific studies comparable.

In a study of 497 asymptomatic women (age 18-83 years) presenting for routine gynecological care, $4 \%$ had normal support, and $45 \%$ had stage I, $48 \%$ stage II, and $3 \%$ stage III POP (10). A cross-sectional study of Slieker et al. demonstrated a prevalence of symptomatic POP of $11.4 \%$ in women aged $45-85$ years (11).

The POPQ stage is a poor predictor of prolapse symptoms. In a group of women having POP of POPQ stage II, women may have or not have complaints.

The prevalence of symptoms of prolapse rises steadily with increasing extent of prolapse along a continuum. Ghetti et al. have described that the prevalence of bulge symptoms within stage II varied from $57 \%$ at $1 \mathrm{~cm}$ above the hymenal remnants to $87 \%$ at $1 \mathrm{~cm}$ below the hymenal remnants (12). Within stage III and IV, up to $90 \%$ of women reported a bothersome vaginal bulge. The turning point that a prolapse is causing symptoms according to Ghetti et al. seemed to be in stage II. Slieker et al. have shown that only $6.9 \%$ of women diagnosed with stage I, $15.8 \%$ diagnosed with stage II and $43.3 \%$ with stage III had symptoms of prolapse compared to $100 \%$ of women with stage IV prolapse (4). There is no clear consensus, however, on the level of prolapse which represents a variation in normal vaginal support and what represents disorder, although most experts would agree that prolapse beyond the hymen is clinically significant.

This illustrates that the staging of the protrusion of the vaginal wall according to the POPQ classification alone is not helpful in distinguishing those women with and without complaints. POP is apparently not only an anatomical problem, but it is a manifestation of an underlying functional problem.

\section{Surgical treatment}

The lifetime risk for women to be operated because of POP is $7 \%-20 \%(13,14)$, In the Netherlands yearly 13,000 patients undergo surgical correction because of POP (15). These operations are known to have a high re-operation rate $(30 \%)$ because of primarily failure and secondary recurrence (13). The anterior compartment is most prone for recurrence after surgery (16). In studies the anatomic success rate of the anterior colporrhaphy ranges from $40-60 \%$ (1). There is a great difference between the number of women with anatomical recurrences and the number of women who have subjective feelings of recurrent prolapse. Anatomical recurrence is defined by the ICS as stage II POP in the operated compartment. As was discussed in the section on symptoms and physical examination most experts would agree that prolapse beyond the hymen is clinically significant. Hence a considerable amount of women 
without having symptoms of recurrence do have an anatomic recurrence. More and more it is acknowledged that a shift is necessary from anatomic reconstructive surgery towards functional reconstructive surgery.

Operative options may be divided into those with a vaginal and those with an abdominal approach. There are different anatomical structures that may be used for restoration of support during surgery, such as the sacrospinous ligaments, but also a decision about the removal of the uterus needs to be made. Vaginal mesh materials may be used to reconstitute support. All these treatments have their specific pros and cons and there is still little scientific information on the most effective treatment in a specific type of prolapse. The choice for a treatment option is thus also highly dependent on the surgeon's preference. The surgical method studied in this thesis was the anterior colporrhaphy. It is one of the oldest procedures and a widely used intervention. The principal of this surgical method is central plication of the fibromuscular layer of the anterior vaginal wall. The success rate of this procedures ranges from $40-60 \%$ in trials $(17,18)$.

\section{Considerations on additional examination}

Physical examination is the gold standard for preoperative evaluation of POP. However, it remains often difficult to make a correct diagnosis on clinical examination alone, especially in case of multi-compartment problems and/or posterior compartment prolapse. Physical examination e.g. detects only $50 \%$ of enteroceles in women with POP having a visible enterocele on evacuation proctography (19). Moreover, certain issues are left out of consideration in the POPQ, such as perineal descent, anterior shift of rectocele, intussusception or enteroceles. Additional imaging of the pelvic floor may be used to confirm the evaluation as performed by clinical examination, might further elucidate possible causes of the prolapse, and could give complementary information on issues to prevent underestimation and incomplete or incorrect surgery.

To understand which treatment is most effective in a woman with POP, it is necessary to better understand what caused the protrusion of the vaginal wall. Whether the protrusion of the vaginal wall is a result of a central defect in the vesico-vaginal fascia, a disruption of the lateral attachment of the anterior vaginal wall to the arcus tendineus, a major levator defect of the attachment of the levator ani muscle to the ramus inferior of the symphysis, an insufficient control of the pelvic floor muscles due to neurological or cognitive problems, a perineal laxity resulting in perineal descent, or a defect of the recto-vaginal fascia, is a matter of ongoing debate. No widespread standardized assessments are available in this respect and clinical relevance with regard to subjective symptoms and treatment options are unclear. All these factors can lead to a similar protrusion of the vaginal wall and, without further analysis of the underlying problem, may result in the choice for the same - frequently ineffective treatment. 


\section{Pelvic floor ultrasound}

In pelvic floor ultrasound the 2D mode is used for visualizing the pelvic floor muscles, the pubic bone, bladder, urethra, rectum, anal canal, uterus and vaginal vault. The ultrasound scan can be recorded as a cineview while the patient is contracting the pelvic floor, while she is performing a Valsalva maneuver or while she is coughing. In the 2D mode one can study the pelvic floor position and function, and mobility of different pelvic organs. In the 3D mode the integrity of levator ani muscle and the hiatal area as well as the influence of Valsalva and contraction on the levator muscle configuration and on the hiatal area can be visualized.

Pelvic floor ultrasound seems an ideal new diagnostic tool in analyzing the patient with POP because of the low costs, the non-invasive character, the absence of ionizing radiation, the easy accessibility for all gynecologists, the immediate availability of the results, and the easiness to implement because all Dutch gynecologists are already skilled in performing gynecological vaginal ultrasound. In theory, even in case pelvic floor ultrasound would not reach the quality of being the gold standard, it might be cost effective to have ultrasound as a screening tool to decide which patient should have further diagnostic examination by MRI or defecography. Today's MRI provides very detailed anatomical information. With the further technological development of imaging the direction of the muscle fibers, there is a high potential to gain more knowledge on anatomy and function of the pelvic floor. However, MRI seems less suitable as a diagnostic tool because of its high costs and limited accessibility.

Several small studies showed good inter and intraobserver agreement for translabial ultrasound of the pelvic floor (20). The amount of information that can be obtained from these ultrasound scans varies with the machine and the settings that have been used. Dietz published a monograph on pelvic floor ultrasound, containing a chapter on the technological aspects of pelvic floor ultrasound (21). In this chapter different software applications in use have been reviewed. However, no details were given to select the best application for 2D or 3D mode. No studies have yet been published on the equipment settings that matter in pelvic floor ultrasound.

There is little comparative research between MRI and 3D ultrasound imaging of the pelvic floor, especially to evaluate levator defects and their clinical relevance. Direct comparison of studies using MRI with studies using ultrasound for diagnosing levator defects is limited due to different scoring and classification systems. It is not clear whether the cut-off between a minor and a severe grade levator defect on ultrasound is identical to the cut-off used in MRI. This hampers the comparison of studies using different imaging modalities and scoring systems.

Notwithstanding the growing number of publications in the literature on the promising role of pelvic floor ultrasound, many aspects of pelvic floor ultrasound are still poorly understood and not yet standardized. 


\section{Outline of this thesis}

This thesis will explore pelvic floor ultrasound as an additional diagnostic tool for the analysis of a patient with POP. The main research topics in this thesis will be the following.

\section{What is the role of pelvic floor ultrasound in women with anterior compartment prolapse?}

In chapter 2 a randomized controlled trial will be described in which 245 women underwent anterior colporrhaphy because of a cystocele POPQ stage II or more. Patients were randomly assigned to a post-operative protocol of indwelling catheterization after an anterior colporrhaphy for 2 or for 5 days.

In chapter 3 the follow up of these patients will be described. Hundred fifty six women joined the prospective observational follow-up study, 2 years after their anterior colporrhaphy for cystocele POPQ stage II or more. This study concerns the recurrences rate after anterior colporrhaphy and specific risk factors for recurrence. One of the risk factors studied, are defects of the levator ani muscle, diagnosed by pelvic floor ultrasound.

\section{What is the role of pelvic floor ultrasound in women with posterior compartment prolapse?}

In chapter 4 a prospective observational study will be described in which 50 patients underwent translabial ultrasound and evacuation proctography. In this study the level of agreement between translabial ultrasound and evacuation proctography is assessed for diagnosing enteroceles and intussusceptions. The results will be discussed in the context of the available literature.

\section{Which ultrasound machine settings result in the best quality images in pelvic floor ultrasound?}

In chapter 5 a study will be presented on the settings that matter in pelvic floor ultrasound. In this study 5 observers assessed the quality of pelvic floor ultrasound images of five healthy volunteers. By analyzing the best quality images in the 2D mode and the 3D mode the ultrasound machine settings are identified relevant for optimizing the quality of these ultrasound scans.

\section{Which scoring system should we use to describe levator defects on pelvic floor ultrasound?}

In chapter 6 a comparison will be made between 2 scoring systems to describe levator defects. The classification as described by Dietz for ultrasound and the classification as 
described by Delancey for MRI are compared (22-24). It will be determined whether the score of MRI can be used for diagnosing levator defects on pelvic floor ultrasound in order to make it possible to compare findings of both imaging modalities in future comparative studies. 


\section{References}

1. Hunskaar S, Burgio K, Clark A, et al. Epidemiology of urinary and fecal incontinence and pelvic organ prolapse. In: Abrams P, Cordozo L, Koury S, Wein A, eds. Third international consultation on incontinence, 1st edn. Paris: Health Publication, 2005.

2. Hendrix SL, Clark A, Nygaard I, Aragaki A, Barnabei V, McTiernan A. Pelvic organ prolapse in the Women's Health Initiative: gravity and gravidity. Am J Obstet Gynecol 2002;186:1160-6.

3. Schaffer JI, Wai CY, Boreham MK. Etiology of pelvic organ prolapse. Clin Obstet Gynecol 2005;48: 639-47.

4. Jelovsek JE, Maher C, Barber MD. Pelvic organ prolapse. Lancet 2007;369:1027-38.

5. Mant J, Painter R, Vessey M. Epidemiology of genital prolapse: observations from the Oxford Family Planning Association Study. Br J Obstet Gynaecol 1997;104:579-85.

6. DeLancey JO, Kearney R, Chou Q, Speights S, Binno S. The appearance of levator ani muscle abnormalities in magnetic resonance images after vaginal delivery. Obstet Gynecol 2003;101:46-53.

7. Dietz HP, Simpson JM. Levator trauma is associated with pelvic organ prolapse. BJOG 2008;115: 979-84.

8. Dietz HP, Chantarasorn V, Shek K. Levator avulsion is a risk factor for cystocele recurrence. Ultrasound Obstet Gynecol 2010;36:76-80.

9. Bump RC, Mattiasson A, Bo K, Brubaker LP, DeLancey JO, Klarskov P, Shull BL, Smith AR. The standardization terminology of female pelvic organ prolapse and pelvic floor dysfunction. Am J Obstet Gynecol 1996;175:10-17.

10. Swift SE, Tate SB, Nicholas J. Correlation of symptoms with degree of pelvic organ support in a general population of women what is pelvic organ prolapse. Am J Obstet Gynecol 2003;189:372-77.

11. Slieker-ten Hove MC, Pool-Goudzwaard AL, Eikemans MJ, Steegers-Theunissen RP, Burger CW, Vierhout ME. Symptomatic pelvic organ prolapse and possible risk factors in a general population. Am J Obstet Gynecol 2009;200:184 e1-7.

12. Ghetti C, Gregory WT, Edwards SR, Otto LN, Clark AL. Pelvic organ descent and symptoms of pelvic floor disorders. Am J Obstet Gynecol 2005;193:53-7.

13. Olsen AL, Smith VJ, Bergstrom JO, Colling JC, Clark AL. Epidemiology of surgically managed pelvic organ prolapse and urinary incontinence. Obstet Gynecol 1997;89:501-6.

14. De Boer TA, Slieker-Ten Hove MC, Burger CW, Kluivers KB, Vierhout ME. The prevalence and factors associated with previous surgery for pelvic organ prolapse and/or urinary incontinencein a crosssectional study in the Netherlands. Eur J Obstet Gynecol Reprod Biol 2011;158:343-9.

15. Prismant 2007.

16. Miedel A, Tegerstedt G, Morlin B, Hammarstrom M. A 5-year prospective follow-up study of vaginal surgery for pelvic organ prolapse. Int Urogynecol J Pelvic Floor Dysfunct 2008;9:1593-601.

17. Weber AM, Walters MD, Piedmonte MR, Ballard LA. Anterior colporrhaphy: a randomized trial of three surgical techniques. Am J Obstet Gynecol 2001;185:1299-304.

18. Sand PK, Koduri S, Lobel RW, Winkler HA, Tomezsko J, Culligan PJ, Goldberg R. Prospective randomized trial of polyglactin 910 mesh to prevent recurrence of cystoceles and rectoceles. Am J Obstet Gynecol 2001;184:1357-62.

19. Kelvin FM, Hale DS, Maglinte DDT, Patten BJ, Benson JT. Female pelvic organ prolapse: diagnostic contribution of dynamic cystoproctography and comparison with physical examination. AJR 1999; 173:31-7.

20. Dietz HP, Steensma AB. The prevalence of major abnormalities of the levator ani in urogynaecological patients. BJOG 2006;113:225-30.

21. Dietz HP, Hoyte LPX, Steensma AB. Atlas of pelvic floor ultrasound. Springer-Verlag London Limited 2008 ISBN 978-1-84628-520-2.

22. DeLancey JO, Morgan DM, Fenner DE, Kearney R, Guire K, Miller JM, Hussain H, Umek W, Hsu Y, Ashton-Miller JA. Comparison of levator ani muscle defects and function in women with and without pelvic organ prolapse. Obstet Gynecol 2007;109:295-302.

23. Kearney R, Miller JM, Ashton-Miller JA, DeLancey JO. Obstetric factors associated with levator ani muscle injury after vaginal birth. Obstet Gynecol 2006;107:144-9. 
24. Dietz HP, Bernardo MJ, Kirby A, Shek KL. Minimal criteria for the diagnosis of avulsion of the puborectalis muscle by tomographic ultrasound. Int Urogynecol J 2011;22:699-704. 


\section{Chapter 2}

Postoperative catheterization after anterior colporrhaphy:

2 versus 5 days. A multicentre randomized controlled trial

Weemhoff M, Wassen MMLH, Korsten L, Serroyen J, Kampschöer PHNM, Roumen FJME

Int Urogynecol J 2011/ 22:477-483 


\section{Abstract}

Aim

The aim of this study was to compare the number of temporary catheter replacements and urinary tract infections after indwelling catheterization for 2 versus 5 days following an anterior colporrhaphy.

\section{Methods}

Two hundred forty-six patients were randomly assigned to 2 or 5 days of indwelling catheterization. Outcome measures were temporary catheter replacements because of postvoiding residual $>200 \mathrm{ml}$ after removal of the indwelling catheter, urinary tract infections, and hospital stay. All patients were analyzed according to the intention to treat principle.

\section{Results}

Compared to the 5-day protocol group, in the 2-day protocol group more patients needed temporary catheter replacement ( $9 \%$ versus $28 \%$, odds ratio (OR) 4.0 , confidence interval $(\mathrm{Cl})$ $1.9-8.3, \mathrm{p}<0.01)$, whereas less patients had a urinary tract infection $(37 \%$ versus $22 \%, \mathrm{OR} 0.5, \mathrm{Cl}$ $0.3-0.9, p=0.02$ ) and median hospital stay was lower.

\section{Conclusions}

Removal of an indwelling catheter after 2 versus 5 days following anterior colporrhaphy is associated with more temporary catheter replacements, but less urinary tract infections and a shorter hospital stay. 


\section{Introduction}

A nationwide questionnaire-based survey in 99 hospitals in The Netherlands has shown a mean duration of catheterization of 3.7 days (1-7 days) following an anterior colporrhaphy (1). Drainage of urine is being performed to reduce the risk of retention by postoperative edema of the bladder. Overfilling of the bladder might have a negative impact on the surgical outcome (2). Only 3 studies have been published on the effects of the duration of postoperative indwelling catheterization following an anterior colporrhaphy. The first study in 106 women did not find a significant difference in incidence of urinary retention between catheter removal on the first (24\%) and third day (31\%) postoperatively (3). It was concluded that the indwelling catheter can be removed on the first day postoperatively. A subsequent underpowered study in $\mathbf{5 0}$ patients did not find a difference in incidence of urine retention between the first and third postoperative day either, but showed considerably lower retention percentages in both groups (8\%) (4). In contrast, a randomized controlled trial in The Netherlands in 100 patients showed $40 \%$ of patients having a post-voiding residual of more than $200 \mathrm{ml}$ after removal of the catheter on the first postoperative day versus $9 \%$ of patients having retention after removal of the catheter on the fifth postoperative day (2). We concluded that removal of the indwelling catheter on the first day postoperatively is too soon. Based on these conclusions, we hypothesized that 2 days of postoperative indwelling catheterization after an anterior colporrhaphy is more appropriate than 5 days, which is most commonly applied in The Netherlands.

Bladder catheterization, however, increases the risk of urinary tract infections (5). After removal of the catheter on the first day postoperatively, only $4 \%$ of patients had infections, compared to $20 \%$ when the catheter had been removed on the third day and $40 \%$ after removal of the catheter on the fifth day $(2,4)$.

In a retrospective study, high-grade cystocele, higher intra-operative blood loss, Kelly plication, and levator plication were identified by multivariable analysis as independent risk factors for short-term urinary retention after vaginal prolapse surgery (6).

The aim of the present study was to determine in a randomized controlled trial the incidence of bladder retention and urinary tract infections after postoperative indwelling catheterization for 2 days versus indwelling catheterization for 5 days.

\section{Methods}

Between January 2006 and September 2008, a randomized controlled trial was performed in 3 different hospitals in patients undergoing an anterior colporrhaphy comparing postoperative temporary indwelling catheterization for 2 days versus indwelling catheterization for 5 days. The primary outcome measure was the number 
of temporary catheter replacements after the first removal of the catheter postoperatively. A catheter was temporarily replaced in case the residual volume after micturition was more than $200 \mathrm{ml}$. Despite the definition of the International Continence Society (ICS) for bladder retention, which is one third of the bladder volume, the cut-off value of $200 \mathrm{ml}$ was chosen to make the results of the study comparable to those of another study (2). Secondary outcome measures were the rate of urinary tract infections and the length of the hospital stay. Furthermore, the factors that appeared to be associated with post-voiding residuals more than $200 \mathrm{ml}$ after removal of the catheter in univariable regression were assessed by multivariate logistic regression to find out if they were independent risk factors for temporary catheter replacements. The assessed factors in univariable analysis were age, BMI, history of obstructive micturition or recurrent urinary tract infections, advanced stage of prolapse preoperatively, used operation techniques, concomitant surgery, mean amount of blood loss, urinary tract infections, and the protocol for catheterization used.

All patients with a cystocele undergoing an anterior colporrhaphy were eligible. As the POPQ classification was not generally introduced in daily practice at the study start, prolapse was staged at the outpatient clinic according to the Baden-Walker classification. Stage I was a cystocele, rectocele, or descensus uteri into the first half of the vagina, in stage II the prolapse protruded into the distal half of the vagina, in stage III the prolapsed tissue bulged out of the vagina, and stage IV was a total protrusion of the bladder, rectum, or uterus.

Doctors were encouraged to perform the anterior repair as they were used to. Combinations with other vaginal operations like hysterectomy, sacrospinal fixation, or posterior colporrhaphy were allowed. Excluded were women who were performing self-catheterization because of voiding dysfunctions preoperatively, women under 18 years of age, and those who were not able to understand informed consent because of low IQ or a language barrier. After informed consent, patients were included at the outpatient clinic at the time the operation was planned. The protocol was approved by the medical ethical committees of the three participating hospitals.

Patients were randomized to postoperative temporary indwelling catheterization for either 2 or 5 days. A randomization list was made by an independent statistician. Randomization was performed in blocks and was stratified for the different hospitals. According to the randomization list, opaque, numbered, and sealed envelopes were prepared by an independent person. At the start of the operation, urine was collected for sedimentation. After the operation was finished, the indwelling catheter was inserted; the envelope with study number was opened, and at that moment, the patient was randomized to temporary indwelling catheterization for either 2 or 5 days.

The catheter was removed in the morning of the second or fifth day postoperatively. The residual volume was measured by bladder ultrasound scan $6-8 \mathrm{~h}$ later. A residual volume after micturition of more than $200 \mathrm{ml}$ was considered abnormal, and a new 
indwelling catheter was inserted. A required minimum void was not defined. The next morning, the catheter was removed, and again the post-voiding residual volume was assessed 6-8 $\mathrm{h}$ later. If the volume was still more than $200 \mathrm{ml}$, a new catheter was inserted, this time for 3 days. In case the residual volume was still more than $200 \mathrm{ml}$ after these 3 extra days, the patient started intermittent self-catheterization until the residual volume after spontaneous micturition was less than $200 \mathrm{ml}$.

All patients received prophylactic antibiotics at the beginning of the operation. Postoperative prophylactic antibiotics were not given routinely. After removal of the catheter, urine samples were taken for sedimentation and culture. Patients with complaints and sedimentation showing signs of urinary tract infection were given antibiotics. Signs of urine tract infection were defined as having more than 25 white blood cells per high power field, nitrate production, or more than 20 bacteria per high power field. When urinary tract infection after the removal of the catheter was confirmed by a positive culture, patients were treated with antibiotics irrespective of complaints. A culture was scored positive when the sample contained more than $10^{5}$ colony forming units per milliliter. For the outcome measure urinary tract infection, only the infections proven by a positive culture at the time of the first removal of the catheter were included. No other urinary cultures were taken on behalf of the study protocol.

All patients were given the opportunity to leave the hospital on the third day postoperatively. For patients in the 5-day protocol who requested to leave the hospital with an indwelling catheter in situ, an appointment was made on the fifth day in the outpatient clinic for ultrasound 6-8 $\mathrm{h}$ after removal of the catheter by themselves at home.

The primary outcome measure in the study was the number of patients with temporary catheter replacements after removal of the first indwelling catheter postoperatively. Based on retrospectively collected data in one of the participating hospitals, the average percentage of patients needing repeated catheterization after removal of the catheter on the fifth day after an anterior colporrhaphy was $10 \%$. To show a difference of at least $15 \%$ in the number of repeated catheterizations between the 2- versus 5-day protocol, with a significance of 0.05 and a power of $90 \%$, it was calculated that 112 patients in each group were needed.

The study was started with the intention to include 224 patients. After 2 years of inclusion, an amendment to the study was made to perform long-term follow-up 2 years postoperatively. Therefore, the intended inclusion was increased to 250 patients, taking into account a loss to long-term follow-up of $20 \%$.

All data were collected and analyzed in SPSS 15.0 for Windows. The t test, Pearson chi-square test, Fisher's exact test, and univariable and multivariable logistic regression were used in the statistical analysis of all data. All patients were analyzed according to the intention to treat principle. 


\section{Results}

Between January 2006 and September 2008, 390 patients underwent an anterior colporrhaphy. Figure 2.1 shows the patient flow of the study. Two hundred fifty out of 390 patients (64\%) agreed to be included in the study. Three patients withdrew from the study just before the operation. One patient did not undergo the planned operation because under general anesthesia a tumor in the rectum was palpated and treatment was taken over by the surgeon. Two hundred forty-six patients were randomized after the operation. One patient, randomized to the 2-day protocol, died of a heart attack on the first postoperative day with the catheter in situ. She died before she could participate in the study. Two patients allocated to the 5-day protocol had their catheter removed on the third day because of miscommunication. The 3 patients were analyzed in the allocated group. In $20 \%$ of patients, the protocol was not followed and a culture of the urine was not obtained after removal of the catheter. Follow-up after 6 weeks was achieved in 245 patients.

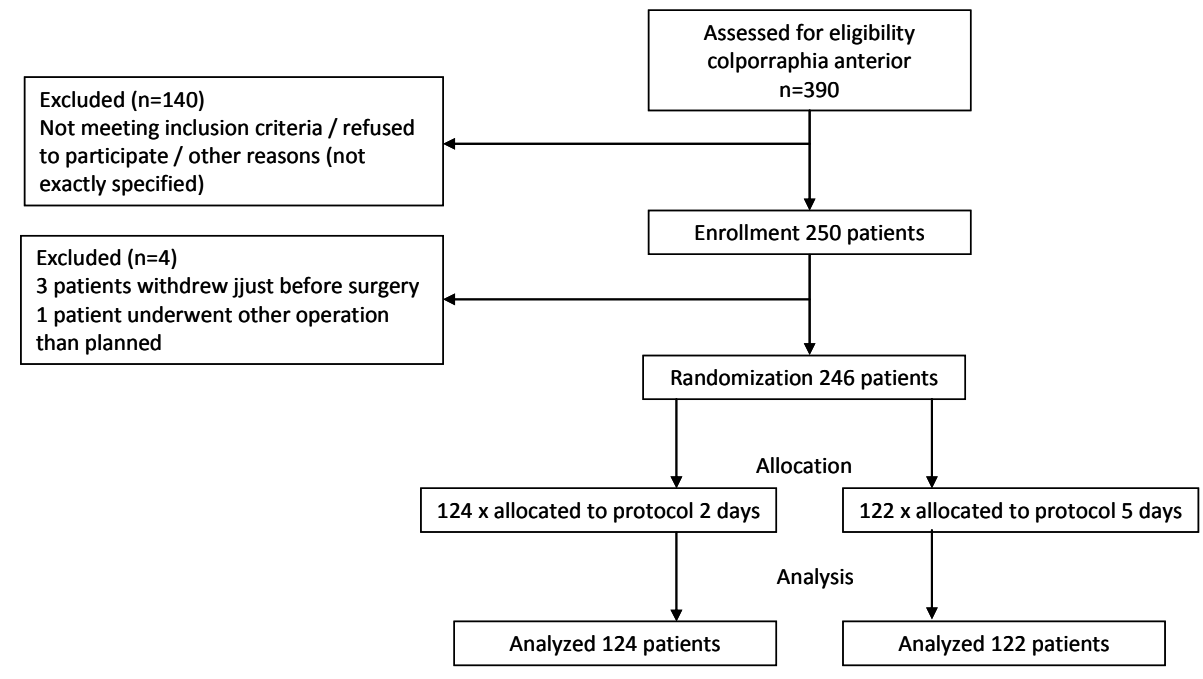

Figure 2.1 Patient flow.

Patient characteristics in both groups are shown in Table 2.1. There were no significant differences between both groups with respect to age, BMI, Baden-Walker classification of cystocele and rectocele, history of symptoms, history of surgery, preoperative urine tract infections, concomitant surgery, mean amount of blood loss and use of levator sutures, or tobacco plication of the bladder. However, more patients 
had undergone Kelly sutures in the 5-day protocol group than in the 2-day protocol group.

Table 2.1 Baseline characteristics of the study population.

\begin{tabular}{|c|c|c|c|}
\hline & $\begin{array}{l}\text { Protocol } 2 \text { days } \\
\text { catheterization } \\
\quad(n=124)\end{array}$ & $\begin{array}{l}\text { Protocol } 5 \text { days } \\
\text { catheterization } \\
\qquad(n=122)\end{array}$ & $p$ value \\
\hline Mean age in years & 59.9 (SD 10.2) & 60.7 (SD 11.1) & 0.57 \\
\hline Mean $\mathrm{BMI}$ in $\mathrm{kg} / \mathrm{m}^{2}$ & 26.6 (SD 3.9) & 26.4 (SD 3.9) & 0.64 \\
\hline \multicolumn{4}{|l|}{ History of surgery } \\
\hline History of prolapse repair & $9 \%(11)$ & $12 \%(15)$ & 0.39 \\
\hline History of hysterectomy & $20 \%(25)$ & $20 \%(24)$ & 0.90 \\
\hline $\begin{array}{l}\text { History of anterior } \\
\text { colporrhaphy }\end{array}$ & $3 \%(4)$ & $7 \%(8)$ & 0.23 \\
\hline History of posterior colporrhaphy & $5 \%(6)$ & $6 \%(7)$ & 0.76 \\
\hline \multicolumn{4}{|l|}{ History } \\
\hline Obstructive micturition & $30 \%(37)$ & $31 \%(38)$ & 0.86 \\
\hline Recurrent urinary tract infections & $8 \%(10)$ & $11 \%(13)$ & 0.50 \\
\hline $\begin{array}{l}\text { Urinary tract infection in pre-operative } \\
\text { sedimentation } \\
\text { Cystocele (Baden-Walker) }\end{array}$ & $5 \%(6)$ & $6 \%(7)$ & 0.76 \\
\hline 1 & $11 \%(14)$ & $11 \%(13)$ & 0.86 \\
\hline II & $35 \%(43)$ & $38 \%(47)$ & 0.56 \\
\hline III & $54 \%(67)$ & $51 \%(62)$ & 0.66 \\
\hline \multicolumn{4}{|l|}{ Rectocele (Baden-Walker) } \\
\hline 0 & $37 \%(45)$ & $37 \%(44)$ & 0.99 \\
\hline I & $34 \%(42)$ & $39 \%(46)$ & 0.50 \\
\hline II & $21 \%(25)$ & $18 \%(21)$ & 0.58 \\
\hline III & $8 \%(11)$ & $7 \%(8)$ & 0.66 \\
\hline \multicolumn{4}{|l|}{ Technique } \\
\hline Kelly sutures & $36 \%(44)$ & $47 \%(58)$ & $<0.01$ \\
\hline Levator sutures & $27 \%(33)$ & $32 \%(39)$ & 0.15 \\
\hline Tobacco sutures & $17 \%(21)$ & $18 \%(22)$ & 0.84 \\
\hline \multicolumn{4}{|l|}{ Concomitant surgery } \\
\hline Hysterectomy & $53 \%(65)$ & $55 \%(67)$ & 0.80 \\
\hline Posterior colporrhaphy & $46 \%(57)$ & $52 \%(63)$ & 0.44 \\
\hline Sacrospinal fixation & $15 \%(19)$ & $13 \%(16)$ & 0.72 \\
\hline Mean amount of blood loss in $\mathrm{ml}$ & 241 & 233 & 0.55 \\
\hline
\end{tabular}

(n) number of patients, SD standard deviation.

Table 2.2 shows the outcome measures of the two groups. Twenty-eight percent of patients in the 2-day protocol needed temporary catheter replacement compared to $9 \%$ of patients in the 5 -day protocol $(p<0.01)$. In 196 patients, urine was sent for culture after removal of the catheter. After 2 days, significantly less patients had urinary tract infections, proven by a culture with $>10^{5}$ colony forming units per milliliter, than after 5 days of catheterization (22\% versus $37 \%, p=0.02$ ). Of all patients, $67 \%$ had an uneventful postoperative period, defined as having no postvoiding residual volume more than $200 \mathrm{ml}$ and having no urinary tract infection at 
time of the first catheter removal. There was no difference between the two protocols in number of patients with an uneventful postoperative period (67\% versus $66 \%$, $p=0.86)$.

Table 2.2 Outcome measures comparing the 2 and 5 days protocol.

\begin{tabular}{lcccc}
\hline & $\begin{array}{c}\text { Protocol } \\
2 \text { days }\end{array}$ & $\begin{array}{c}\text { Protocol } \\
5 \text { days }\end{array}$ & OR $(95 \% \mathrm{Cl})$ & p value \\
\hline $\begin{array}{l}\text { Percentage of patients needing } \\
\text { temporary catheter replacement }(\mathrm{n})\end{array}$ & $28 \%(35 / 123)$ & $9 \%(11 / 122)$ & $4.0(1.9,8.3)$ & $<0.01$ \\
$\begin{array}{l}\text { Percentage of patients with a urinary } \\
\text { tract infection at the time of first }\end{array}$ & $22 \%(22 / 101)$ & $37 \%(35 / 95)$ & $0.5(0.3,0.9)$ & 0.02 \\
$\begin{array}{l}\text { catheter removal }(\mathrm{n})^{\mathrm{a}} \\
\begin{array}{l}\text { Percentage of patients with } \\
\text { uneventful postoperative period }\end{array}\end{array}$ & $67 \%(82 / 123)$ & $66 \%(80 / 122)$ & $1.0(0.6,1.6)$ & 0.86 \\
Hospital stay Median (range) $^{\mathrm{b}}$ & $3.0(2.0-42.0)$ & $5.0(1.0-59.0)$ & & $<0.01$ \\
\hline
\end{tabular}

a Urinary tract infection defined as culture with $>10^{5}$ colony forming unit per milliliter;

${ }^{b}$ Uneventful postoperative period defined as post-voiding residual $<200 \mathrm{ml}$ and no urinary tract infection (culture $<10^{5}$ colony forming unit per milliliter) at time of first catheter removal.

$\mathrm{Cl}=$ confidence interval.

The median duration of hospital stay was shorter in the 2-day protocol group, compared to the 5-day protocol group (median 3 versus 5 days).

To prevent one temporary indwelling catheter replacement, six patients should have their catheter left in place for 5 days instead of 2 days. Giving a patient a catheter for 5 days instead of 2 days lengthened the hospital stay by 2 days.

Table 2.3 shows the association between the two outcome measures: urinary tract infections and temporary catheter replacement. In the whole study population, a urinary tract infection at time of first catheter removal was associated with a postvoiding residual of more than $200 \mathrm{ml}$ needing catheter replacement with an OR of 4.8 $(95 \% \mathrm{Cl} 2.3,10.2, \mathrm{p}<0.01)$. This association was stronger in the 2-day protocol group compared with the 5-day protocol group (OR 12.4; $95 \% \mathrm{Cl} 4.1,37.3, \mathrm{p}<0.01$ versus OR 6.0; 95\% Cl 1.1, 31.6, $p=0.03)$.

Table 2.3 Urinary tract infections proven by a positive culture at the time of the first catheter removal.

\begin{tabular}{|c|c|c|c|}
\hline & $\begin{array}{l}\text { Urinary tract infections } \\
\text { in patients with post- } \\
\text { voiding residual }>200 \mathrm{ml}\end{array}$ & $\begin{array}{l}\text { Urinary tract infections } \\
\text { in patients with post- } \\
\text { voiding residual }<200 \mathrm{ml}\end{array}$ & OR $(95 \% \mathrm{Cl}), \mathrm{p}$ value \\
\hline Prot & $16 / 30(53 \%)$ & $6 / 71(8 \%)$ & $12.4(4.1,37.3$ \\
\hline 5 days & $6 / 8(75 \%)$ & $29 / 87(33 \%)$ & $6.0(1.1,31.6), 0.03$ \\
\hline Total group & $22 / 38(58 \%)$ & $35 / 158(22 \%)$ & $4.8(2.3,10.2),<0.01$ \\
\hline
\end{tabular}

$\mathrm{Cl}=$ confidence interval. 
Table 2.4 shows the univariable and multivariable analyses of different variables to indicate whether they form risk factors for temporary indwelling catheter replacement. The multivariable analysis focused on risk factors for catheter replacement taking into account all significant factors in the univariable analysis. A urinary tract infection at the time of the first removal of the catheter and the protocol for catheterization itself appeared to be the only significant risk factors for temporary catheter replacement.

Table 2.4 Risk factors for temporary catheter replacement after anterior colporrhaphy.

\begin{tabular}{|c|c|c|c|c|c|c|}
\hline \multirow[t]{2}{*}{ Possible risk factors } & \multicolumn{3}{|c|}{ Univariable analysis } & \multicolumn{3}{|c|}{ Multivariable analysis } \\
\hline & OR & $95 \% \mathrm{Cl}$ & $p$ value & OR & $95 \% \mathrm{Cl}$ & $p$ value \\
\hline Age & 1.0 & $1.0,1.0$ & 0.75 & & & \\
\hline BMI & 1.1 & $1.0,1.2$ & 0.05 & 1.1 & $1.0,1.2$ & 0.09 \\
\hline \multicolumn{7}{|l|}{ History } \\
\hline Obstructive micturition & 1.3 & $0.6,2.7$ & 0.46 & & & \\
\hline Recurrent urinary tract infections & 2.6 & $0.6,11.5$ & 0.21 & & & \\
\hline $\begin{array}{l}\text { Urinary tract infection in pre-operative } \\
\text { sedimentation }\end{array}$ & 0.78 & $0.2,3.6$ & 0.75 & & & \\
\hline Pre-operative grade III cystocele (BW) & 1.2 & $0.7,2.4$ & 0.52 & & & \\
\hline \multicolumn{7}{|l|}{ Technique } \\
\hline Kelly sutures & 0.7 & $0.3,1.3$ & 0.26 & 2.3 & $0.8,6.3$ & 0.11 \\
\hline Levator sutures & 0.8 & $0.4,1.7$ & 0.58 & & & \\
\hline Tobacco sutures & 3.4 & $1.6,7.1$ & $<0.01$ & & & \\
\hline \multicolumn{7}{|l|}{ Concomitant surgery } \\
\hline Hysterectomy & 0.9 & $0.5,1.8$ & 0.80 & & & \\
\hline Posterior colporrhaphy & 2.0 & $1.1,3.9$ & 0.04 & 1.9 & $0.8,4.7$ & 0.12 \\
\hline Mean amount of blood loss in $\mathrm{ml}$ & 1.0 & $1.0,1.0$ & 0.07 & & & \\
\hline $\begin{array}{l}\text { Protocol of } 2 \text { days catheterization } \\
\text { (compared to } 5 \text { days catheterization) }\end{array}$ & 4.0 & $1.9,8.4$ & $<0.01$ & 11.1 & $3.8,32.1$ & $<0.01$ \\
\hline $\begin{array}{l}\text { Urinary tract infection at the time of } \\
\text { the first catheter removal }\end{array}$ & 4.8 & $2.3,10.2$ & $<0.01$ & 9.1 & $3.4,23.8$ & $<0.01$ \\
\hline
\end{tabular}

$\mathrm{Cl}=$ confidence interval.

\section{Discussion}

The reason for prolonged drainage of urine by an indwelling catheter after an anterior repair is that postoperative edema of the bladder, or innervation trauma of the bladder, can cause voiding difficulties with increasing risk of retention. Overfilling of the bladder might possibly have a negative impact on the surgical outcome (2). The question is how long postoperative catheterization should be continued. A Cochrane review focusing on catheterization of adults undergoing a urogenital procedure was not able to draw conclusions on whether a catheter should be inserted after an 
anterior repair for a shorter or longer period postoperatively to prevent repeated catheterizations (7).

In our study, $28 \%$ of patients in the 2-day protocol needed repeated temporary catheterization compared to $9 \%$ of patients in the 5 -day protocol $(p<0.01)$. These results are in line with a previous study, in which $40 \%$ of patients had retention after removing the catheter on the first postoperative day versus $9 \%$ of patients after removing the catheter on the fifth postoperative day (2). To prevent one patient from needing repeated temporary catheterization, 6 patients in our study should have their catheter left in place for 5 days instead of 2 days. Giving a patient a catheter for 5 days instead of 2 days lengthened the hospital stay by 2 days, resulting in considerably higher hospital costs. This confirms findings by other investigators (7). However, lengthening of hospital stay is probably not the result of the medical condition per se, but merely a result of the reluctance of many patients to leave the hospital with an indwelling catheter in situ and anxiety about removing the catheter by themselves.

More patients underwent Kelly sutures in the 5-day protocol group compared to the 2-day protocol group. Kelly sutures, theoretically, can obstruct the urethra causing obstructive voiding with the risk of post-voiding residual volumes. If Kelly sutures had influenced the results of the study, they would have had a negative impact on the amount of catheter replacements in the 5-day protocol group. In contrast to others and to the theoretical concept, Kelly plication was not found an independent risk factor for repeated temporary catheterization in our study (8).

In our study, significantly less patients had urinary tract infections after 2 days than after 5 days of catheterization ( $22 \%$ versus $37 \%, p=0.02$ ). These findings are similar to previous studies, in which only $4 \%$ of patients had infections after removing the catheter on the first day postoperatively, compared to $20 \%$ on the third day and $40 \%$ on the fifth day $(2,4)$. The presence of urinary tract infections was associated with a higher number of temporary catheter replacements both in the 2-day protocol and the 5-day protocol group.

There are several weaknesses of this study that have to be acknowledged. One could criticize the choice of comparing postoperative catheterization for 2 and 5 days. Many surgeons do remove the catheter earlier than after 5 days postoperatively. Nevertheless, in the literature, there is no clear evidence that it is better to remove a catheter shortly after pelvic floor surgery other than the subjective feeling that 5 days is long. The participating hospitals were used to give a catheter for 5 days, and referring to an average catheterization in 2003 of 3.7 days in the hospitals in The Netherlands, longer duration of catheterization was not uncommon. ${ }^{1}$ One of the outcome measures of the study was the rate of urinary tract infections after the first catheter removal. In $20 \%$ of patients, no urine for culture was obtained after removal of the catheter. With 196 patients, the power of the study for this question is still sufficient, but it is likely that in patients with complaints, the risk of forgetting to obtain urine for culture is not that high as in patients with no complaints. It is possible that the percentage of infections was lower if cultures had been taken in all 
245 patients. Because this protocol violation occurred equally in both arms ( 27 versus 24 patients), it causes no differences between the two arms of the study.

\section{Conclusions}

Based on the results of this study, we advise removing an indwelling catheter after an anterior repair on the second day postoperatively, followed by taking a urine culture. In case of a urinary tract infection, the risk of temporary catheter replacement is increased. 


\section{References}

1. Hakvoort RA, Burger MP, Emanuels MH, Roovers JP. A nationwide survey to measure practice variation of catheterization management in patients undergoing vaginal prolapse surgery. Int Urogynecol J 2009;20:813-818.

2. Hakvoort RA, Elberdink R, Vollebregt A, Ploeg vd T, Emanuel MH. How long should urinary bladder catheterization be continued after vaginal prolapse surgery? A randomized controlled trial comparing short term versus long term catheterization after vaginal prolapse surgery. BJOG 2004;111:828-830.

3. Guzman S, Israel E, Puente R, Iglesias R, Rosa G, Uloa C. Handling of Foley catheter regarding urinary retention syndrome following vaginal surgery. Rev Chil Obstet Ginecol 1994;59:280-283.

4. Alonzo-Sosa JE, Flores Contreras JT, Pardes-Canul M. Method for transurethral catheterization for 1-3 days for pelvic floor relaxation in the postoperative period. Ginecol Obstet Méx 1997;65:455-457.

5. Niël-Weise BS, van den Broek PJ. Antibiotic policies for short-term catheter bladder drainage in adults. Cochrane Database of Systematic Reviews 2005, Issue 3. Art. no.: CD005428.

6. Hakvoort RA, Dijkgraaf MG, Burger MP, Emanuel MH, Roovers JPWR. Predicting short-term urinary retention after vaginal prolapse surgery. Neurourol Urodyn 2009;28:225-228.

7. Phipps S, Lim YN, McClinton S, Barry C, Rane A, N'Dow JMO. Short term urinary catheter policies following urogenital surgery in adults. Cochrane Database of Systematic Reviews 2006, Issue 2. Art. no.: CD004374.

8. Thaweekul Y, Bunyavejchevin S, Wisawasukmongchol W, Santingamkun A. Long term results of anterior colporrhaphy with Kelly plication for the treatment of stress urinary incontinence. J Med Assoc Thai 2004;87:357-360. 


\section{Chapter 3}

\section{Avulsion of puborectalis muscle and other risk factors for cystocele}

recurrence:

a 2 year follow up study

Weemhoff M, Vergeldt TFM, Notten K, Serroyen J, Kampschöer PHNM, Roumen FJME

Int Urogynecol J 2012;23:65-71 


\section{Abstract}

Aim

This study aimed to determine the relationship of recurrent cystocele with avulsion of puborectalis muscle and other risk factors.

\section{Methods}

In this prospective observational cohort study, 245 women undergoing anterior colporrhaphy were invited for a 2 year follow-up visit consisting of a questionnaire, physical examination and translabial 3D-ultrasonography. Women with and without recurrent cystocele were compared to identify recurrence risk factors.

\section{Results}

Of the 245 women, 156 agreed to the follow-up visit (63.7\%). Objective recurrence rate was 80 of $156(51.3 \%)$. Seventeen of the $156(10.9 \%)$ reported subjective recurrence. Risk factors for anatomical recurrence were complete avulsion of puborectalis muscle (OR $2.4,95 \% \mathrm{Cl} 1.3,4.7)$, advanced preoperative stage (OR $2.0,95 \% \mathrm{Cl} 1.0,4.1)$, family history of prolapse (OR $2.4,95 \% \mathrm{Cl}$ $1.2,4.9)$, and sacrospinous fixation (OR $6.5,95 \% \mathrm{Cl} 2.0,21.2$ ).

\section{Conclusions}

Risk factors for anatomical cystocele recurrence after anterior colporrhaphy were complete avulsion of puborectalis muscle, advanced preoperative stage, family history of prolapse and sacrospinous fixation. 


\section{Introduction}

The estimated lifetime risk of a woman for undergoing surgery for pelvic organ prolapse (POP) or urinary incontinence is $11.1 \%$. These operations are known to have a high re-operation rate $(30 \%)$ because of primary failure and secondary recurrence (1). The anterior compartment is most commonly affected in POP and is also the most prone for recurrence after surgery $(2,3)$.

Little is known about the factors associated with failure of surgical correction. Probably the factors that play a role in the occurrence of POP in the first place are also risk factors for recurrence of prolapse after surgery. Risk factors for POP that have been described in literature are aging $(4,5)$, obesity $(4,6)$, family history of prolapse $(7,8)$ and collagen weakness $(5)$. Furthermore there is a strong relationship between vaginal child birth and POP $(4,7,9)$. Vaginal birth gives a 4 to 11 fold increase in risk for developing POP among parous women compared to women without vaginal delivery in their history (10). It has been postulated that avulsions of the puborectalis muscle are the intermediary between vaginal deliveries and POP (11).

Studies with MRI and pelvic floor ultrasound have demonstrated the occurrence of trauma to the levator ani after vaginal birth. In $20-23 \%$ of women who had delivered vaginally, trauma of the levator ani was identified $(12,13)$. No defects were seen in nulliparous women. POP was seen in $83 \%$ of women with levator defects and in $44 \%$ women without levator defects. The association was strongest for cystocele and uterine prolapse. Furthermore, women with prolapse appeared to have more major levator defects than controls without prolapse (55\% compared with $16 \%$ ). Women with and without prolapse were equally likely to have minor defects (14).

The aim of the present study was to estimate the rates of anatomical and subjective recurrence after anterior colporrhaphy, to determine whether avulsion of the puborectalis muscle is a risk factor for recurrence of cystocele and to identify other risk factors associated with recurrence.

Identifying patients at risk for recurrent POP after surgery offers the opportunity for individualizing counseling, and adapting treatment and prevention to the individual risk of recurrence.

\section{Methods}

Between January 2006 and September 2008, 245 women undergoing an anterior colporrhaphy were enrolled in a multicentre randomized controlled trial comparing indwelling catheterization for 2 and 5 days following surgery respectively (15). Two years later these women were approached again and invited to participate in a followup study. The aim of this study was to estimate the rates of anatomical and subjective recurrence of cystocele 2 years after anterior colporrhaphy, to determine whether 
avulsion of the puborectalis muscle is a risk factor for recurrence of cystocele, and to identify other risk factors associated with this recurrence.

Patients were localized by the address and telephone number that was registered in the hospitals. All patients received written information and were contacted by telephone to ask them for participation to this follow-up study. Patients that agreed to participate were invited for a follow-up visit at the outpatient clinic consisting of a validated questionnaire, a physical examination and translabial 3D-ultrasonography of the pelvic floor. Patients that did not agree with a follow-up visit were invited to complete the questionnaire at home.

The questionnaire that was used was a validated Dutch version of the Urinary Distress Inventory (UDI) $(16,17)$ and the Defecation Distress Inventory (DDI) (18). Questions concerning possible risk factors were added, including weight, length, parity, assisted deliveries, and family history of prolapse (defined as mother or sister with prolapse).

Pelvic examination was performed with the patient in the lithotomy position. Clinical staging of POP according to the Pelvic Organ Prolapse Quantification (POPQ) classification system was performed (19). The examiner was blinded for the patients' answers to the questionnaire and for the results of the ultrasound examination.

A translabial ultrasonography of the pelvic floor was performed in supine position with hips flexed and slightly abducted and after voiding. A GE Voluson 730 expert system (GE Kretz Ultrasound, Zipf, Austria) was used with a 4,8 MHz curved abdominal transducer covered with gel and a condom. The transducer was placed against the perineum in the midsagittal plane with a maximum angle of 70 degrees for 2D imaging. If the 1 . symphysis pubis, 2 . urethra, 3. anal canal and 4. levator ani were visualized in one plane, an axial 4D volume was rendered with a maximum angle of 85 degrees to visualize the hiatus of minimal dimensions. In this plane a 4D volume cine was recorded containing a maximal pelvic muscle contraction to detect abnormal insertion of the puborectalis muscle on the inferior pubic ramus. (Figure 3.1) This method has been described by Dietz and has been shown to be reproducible $(20,21)$. The recorded data sets were analyzed off-line using Voluson GE Kretz 4D-view V 5.1 software (GE Kretz Ultrasound, Zipf, Austria). The ultrasonographers were blinded for the outcome of the questionnaire and pelvic examination. With Tomographic Ultrasound Imaging (TUI), a technique to show the levator ani muscle in multiple slices of $2.5 \mathrm{~mm}$, levator damage was graded according to the scoring system described by Dietz (22). A complete avulsion was diagnosed on tomographic ultrasound if all three central slices, i.e. the plane of minimal dimensions plus slices 2.5 and $5 \mathrm{~mm}$ cranial to this plane, show an abnormal insertion of the puborectalis muscle on the inferior pubic ramus. Several authors have demonstrated the clinical relevance of a complete avulsion as compared to no or only a partial avulsion of the puborectalis muscle for the development of POP $(14,22)$. 


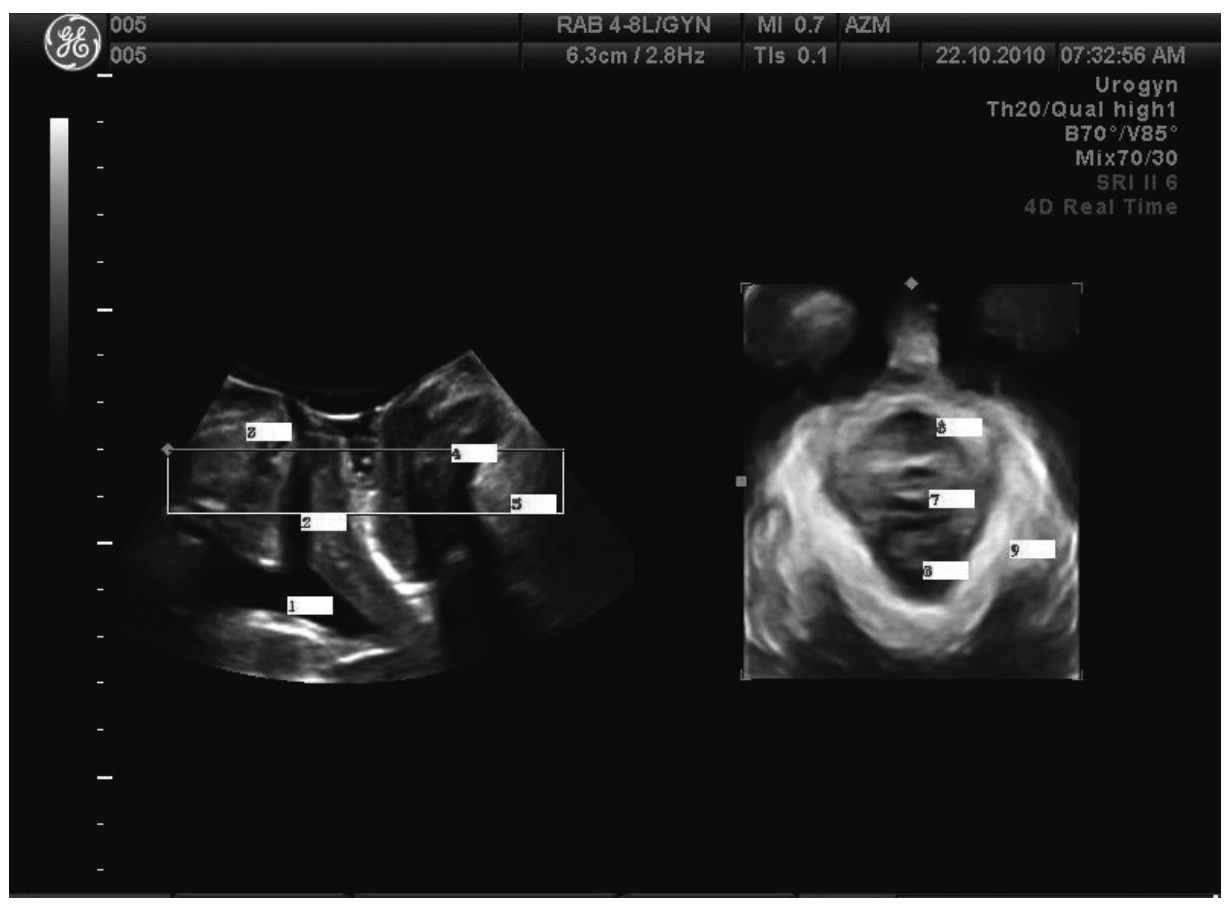

Figure 3.1 3D ultrasonography of Levator muscle. On the right side the midsagittal plane, on the left side the rendered 3D volume of the levator ani muscle. Normal insertion of the puborectalis muscle, no avulsion. 1. bladder; 2. urethra; 3. central axis of symphysis; 4 . anal canal; 5.levator muscle; 6. urethra; 7. vagina; 8. anal canal; 9. levator sling.

Data collected during the follow-up visits and from the returned questionnaires were entered into an existing database. Data on the patients' history, the performed operation, and the surgical technique used had been collected prospectively during the original RCT in 2008 on indwelling catheterization. During that RCT the preoperative grade of prolapse was staged according to the Baden-Walker classification as the POPQ classification was not generally introduced in daily practice yet. Stage I was a cystocele into the first half of the vagina, in stage II the prolapse protruded into the distal half of the vagina, in stage III the prolapsed tissue bulged out of the vagina, and stage IV was a total protrusion of the anterior wall of the vagina.

Anatomical recurrence was defined as an anterior vaginal wall prolapse equal to or greater than stage II of the POPQ classification. Subjective recurrence was defined as 1. feeling and/or 2. seeing a vaginal bulge, with at least a judgment of one of these 2 symptoms as moderately bothersome, or both of these 2 symptoms as somewhat bothersome, according to the scoring system of the validated UDI questionnaire. 
The statistical analysis was performed using the statistical software package SPSS version 16.0 for windows. Women with and without recurrent cystocele were compared to assess the association with age, body mass index (BMI), parity, cystocele stage III or IV before surgery (Baden-Walker classification), assisted deliveries, family history of prolapse (defined as mother or sister with prolapse), constipation, number of compartments involved, combination with vaginal sacrospinous fixation, previous prolapse surgery and complete avulsions of puborectalis muscle.

The independent sample $t$-test was used to compare means of continuous responses. The chi-square test was used to compare categorical variables. Fisher's exact test was performed when the assumptions of the Pearson chi-square test were not reached, i.e. one or more cells contained $<5$ observations. Logistic regression models were employed to calculate odds ratios (OR) and $95 \%$ confidence intervals $(\mathrm{Cl})$. A p-value $<0.05$ was considered statistically significant.

The protocol was approved by the medical ethics committees of each individual participating hospital. All patients who agreed to participate gave written informed consent before enrolment.

\section{Results}

Between November 2009 and April 2010, all 245 participants of a randomized controlled trial focusing on regimen of catheterization after anterior colporrhaphy, were asked to participate in a follow-up study 2 years after the initial operation. From the total of 245 women, 156 agreed to a follow-up visit (63.7\%), 222 women returned the questionnaire (90.6\%), 23 women declined to participate $(9.4 \%)$, among whom 3 women we were unable to localize (1.2\%), 2 suffered from dementia $(0.8 \%)$, and 1 had died at the time of the follow-up study $(0.4 \%)$.

Patient characteristics are shown in Table 3.1. There were no significant differences between women who attended the follow-up visit and women that did not participate with regard to BMI, parity, cystocele stage III or IV before surgery, assisted deliveries, family history of prolapse, constipation, previous prolapse surgery and concomitant surgery in combination with the anterior colporrhaphy. However, the mean age of women who did not attend the follow-up visit was significantly higher than of those who did not attend.

Table 3.2 shows the outcome measures of the results of the operation. The mean follow-up interval was 31 months (range 14-50). 80 of 156 patients (51.3\%) had an anatomical recurrence of the cystocele. Of these, 55 women (68.8\%) had a stage II cystocele, 22 women (27.5\%) had a stage III cystocele, and 3 women (3.8\%) had stage IV cystocele. 17 of 156 women (10.9\%) reported a subjective recurrence. Of the 80 women with anatomical recurrence, $8(10.0 \%)$ were symptomatic compared to 9 of 76 women (11.8\%) without anatomical recurrence. Of the 9 women with subjective recurrence but no anatomical recurrence, only 3 cases could be explained by a 
rectocele. The other 6 women had no objective anatomical prolapse of any compartment. There was no statistically significant correlation between anatomical and subjective recurrence $(p=0.71)$.

Table 3.1 Patient characteristics.

\begin{tabular}{lccc}
\hline & $\begin{array}{c}\text { Follow-up visit } \\
\mathrm{n}=156\end{array}$ & $\begin{array}{c}\text { No follow-up visit } \\
\mathrm{n}=89\end{array}$ & $\mathrm{p}$-value \\
\hline Mean age, years $( \pm \mathrm{SD})$ & $61.4(10.1)$ & $65.8(11.0)$ & $<0.01$ \\
Mean BMI, $\mathrm{kg} / \mathrm{m}^{2}( \pm \mathrm{SD})$ & $26.3(3.7)$ & $26.7(4.1)$ & 0.35 \\
Mean parity, $\mathrm{n}( \pm \mathrm{SD})$ & $2.3(1.1)$ & $2.5(1.0)$ & 0.21 \\
Cystocele grade $\mathrm{III}$ or IV before surgery, $\mathrm{n}$ & $76 / 154(49.4 \%)$ & $54 / 88(61.4 \%)$ & 0.07 \\
& & & \\
History of assisted deliveries, $\mathrm{n}(\%)$ & $21 / 156(13.5 \%)$ & $10 / 89(11.2 \%)$ & 0.66 \\
Family history of prolapse ${ }^{\mathrm{a}}, \mathrm{n}(\%)$ & $63 / 156(40.4 \%)$ & $23 / 65(35.4 \%)$ & 0.49 \\
History of constipation ${ }^{\mathrm{a}}, \mathrm{n}(\%)$ & $27 / 154(17.5 \%)$ & $7 / 52(13.5 \%)$ & 0.50 \\
History of previous prolapse surgery, $\mathrm{n}(\%)$ & $17 / 155(11.0 \%)$ & $9 / 89(10.1 \%)$ & 0.84 \\
Concomitant surgery, $\mathrm{n}(\%)$ & & & \\
$\quad$ Combination with hysterectomy & $85 / 156(54.5 \%)$ & $50 / 89(56.2 \%)$ & 0.80 \\
Combination with posterior repair & $75 / 156(48.1 \%)$ & $45 / 89(50.6 \%)$ & 0.71 \\
Combination with sacrospinal fixation & $22 / 156(14.1 \%)$ & $16 / 89(18.0 \%)$ & 0.42 \\
\hline
\end{tabular}

$\mathrm{SD}=$ Standard Deviation. a Family history of prolapse and constipation were only known in patients who completed the questionnaire

Table 3.2 Recurrence rates of cystocele 2 years after anterior colporrhaphy.

\begin{tabular}{lr}
\hline & Recurrence rates \\
\hline Patients with anatomical recurrence & $80 / 156(53.1 \%)$ \\
Patients with subjective recurrence & \\
- patients that attended the follow-up visit & $17 / 156(10.9 \%)$ \\
- patients that only filled out the questionnaire & $6 / 52(11.5 \%)$ \\
- total population & $23 / 208(11.1 \%)$ \\
Symptomatic patients with anatomical recurrence of cystocele & $8 / 80(10.0 \%)$ \\
\hline
\end{tabular}

Of the 66 patients that only filled out the questionnaire, 52 women answered the questions concerning subjective recurrence. Of these 52 women, 6 women (11.5\%) reported subjective recurrence. In total, of all 208 women who filled out the questions concerning subjective recurrence, the subjective recurrence rate was $11.1 \%$.

Table 3.3 shows the data on avulsions of the puborectalis muscle. In 152 patients it was possible to analyze the images of the ultrasound examination. In 4/156 (2.6\%) patients the ultrasonographers had not been able to visualize all 4 reference points and therefore reading the ultrasound scan was not possible. 30 of 152 women (20\%) had no avulsion, 59 women (39\%) had a partial avulsion, and 63 women (41\%) had a complete avulsion of the puborectalis muscle. Of the 77 women with an anatomical recurrence, 40 women (52\%) had a complete avulsion of the puborectalis muscle as 
compared to 23 of 75 women (31\%) without anatomical recurrence. Of the 17 women with a subjective recurrence only 8 women had an anatomical recurrent prolapse in the operated compartment. From these 8 women there was not one person without an avulsion, 4 women had a partial avulsion and 4 women had a complete avulsion of the puborectalis muscle. In this small group of 8 women symptomatic recurrent prolapse was not associated with complete avulsion. Table 3.4 shows the univariable and multivariable logistic regression analysis of the possible risk factors for anatomical recurrence. Risk factors in univariable analysis for anatomical recurrence were cystocele stage III or IV before surgery, family history of prolapse, sacrospinous fixation, and complete avulsion of puborectalis muscle. These factors appeared to be independent as testing for interaction showed no significance. In multivariable logistic regression analysis all 4 variables turned out to be independently associated with anatomical recurrence: cystocele stage III or IV before surgery (OR 2.0, 95\% Cl 1.0, 4.1 ), family history of prolapse (OR $2.4,95 \% \mathrm{Cl} 1.2,4.9$ ), sacrospinous fixation (OR 6.5, $95 \% \mathrm{Cl} 2.0,21.2)$, and complete avulsion of puborectalis muscle (OR $2.3,95 \% \mathrm{Cl} 1.1$, 4.8).

Table 3.3 Avulsion of puborectalis muscle.

\begin{tabular}{lccc}
\hline & $\begin{array}{c}\text { No anatomical } \\
\text { recurrence }\end{array}$ & Anatomical recurrence & Total \\
\hline No avulsion & $21(28 \%)$ & $9(12 \%)$ & 30 \\
Partial avulsion $^{\mathrm{a}}$ & $31(41 \%)$ & $28(36 \%)$ & 59 \\
Complete avulsion $^{\mathrm{a}}$ & $23(31 \%)$ & $40(52 \%)$ & 63 \\
Total & $75(100 \%)$ & $77(100 \%)$ & 152 \\
\hline
\end{tabular}

a unilateral or bilateral avulsion

Sacrospinous fixation was performed in 22 of the 156 patients attending the follow-up visit (14.1\%). Of these women, 18 patients had an anatomical recurrence of the cystocele and of these 18 women, 3 women (16.7\%) were symptomatic.

Of the 156 women who attended the follow-up visit, 8 had a history of previous anterior colporrhaphy before the inclusion in the randomized controlled trial in 2008. Of these 8 women, 7 had again an anatomical recurrence in this follow-up study. Surprisingly, 3 of 4 women with graft-augmented anterior repair had an anatomical recurrence.

\section{Discussion}

After a mean follow-up of 31 months following an anterior colporrhaphy, our study showed an anatomical recurrence rate of cystocele of $51.3 \%$. Complete avulsion of 
puborectalis muscle was identified as risk factor for recurrence, along with cystocele stage III or IV before surgery, family history of prolapse, and sacrospinous fixation. The anatomical cystocele recurrence rate in our study is consistent with the rate of recurrences described in other studies $(23,24)$. Of the women with anatomical cystocele recurrence, only $10.9 \%$ had subjective recurrence. There was no statistically significant association between anatomical and subjective recurrence. This phenomenon has also been described by others $(3,25)$. On the one hand we know that a single POPQ exam may miss some women with prolapse because of the timing of the clinical examination on the day or the amount of activity performed by the woman. On the other hand a considerable overlap exists between patients with and without symptoms in different stages of POP (26). The prevalence of bulge symptoms rises steadily with increasing extent of prolapse along a continuum. Ghetti et al. described how the frequency of bulge symptoms within stage II, varied from $57 \%$ at -1 to $87 \%$ at +1 . Within stage III and IV, up to $90 \%$ of women reported a bothering bulge. The turning point seems to be in stage II (26). In our study, $68.8 \%$ of women with anatomical recurrence had a POPQ stage II cystocele. This could possibly explain the low subjective recurrence rate in our study.

In our study, complete levator avulsions were associated with anatomical recurrence of cystocele with an odds ratio of $2.3(95 \% \mathrm{Cl} 1.1,4.8)$. In agreement with our study, others found levator defects to be a risk factor for recurrence too with an odds ratio of $7.0(95 \% \mathrm{Cl} 2.6,19.1)(24)$. As other authors described before we did not find an association between partial avulsions of puborectalis muscle and anatomical recurrence $(14,22)$.

In our study only 8 of the 17 women with a subjective recurrence had an anatomical recurrent prolapse in the operated compartment. In these 8 women a symptomatic recurrent prolapse in the operated compartment was surprisingly not associated with a major levator defect. The amount of women with a subjective recurrence of prolapse was too small to generalize this finding, therefore larger studies are needed. Advanced prolapse grade before surgery was also identified as a risk factor for recurrent POP after surgery in other studies $(25,27-29)$. The association we identified between recurrence and family history of prolapse has not been found by others $(25,27)$. In contrast to our study, several others found an association between recurrence and younger age $(3,25,29)$.

There is only one study in the literature comparing cystocele recurrence rates after anterior colporrhaphy with and without sacrospinous fixation (30). In that study, cystocele recurrence rate was $11.7 \%$ versus $9.4 \%$ in patients undergoing anterior colporrhaphy with or without concomitant sacrospinous fixation, respectively. It was concluded that cystocele formation was not altered by performing a sacrospinous fixation. In our present study sacrospinous fixation is a risk factor for anatomical recurrence. We hypothesize that sacrospinous fixation creates an exaggerated posterior vaginal axis resulting in abnormal intra-abdominal pressure on the anterior vaginal wall, resulting in an increased risk for recurrent cystocele formation. However, 
a sacrospinous fixation was performed in only $14.1 \%$ of participants in the follow-up study. Due to the small number of procedures, the OR has a wide $95 \%$ confidence interval $(2.1,22.2)$, which makes this finding less accurate. Further research is indicated.

A weakness of our study is that its accuracy might be challenged because not all women who underwent surgery attended the follow-up visit. On the one hand, it is possible that women with symptoms are more eager to join the study than women without symptoms. On the other hand, it is possible that women who had already been treated for a recurrence are less willing to visit a doctor afterwards. Considering the fact that there are no significant differences in patient characteristics except age, and that the percentages of patients with a subjective recurrence are comparable between the group of women that attended the follow-up visit (10.9\%) and the group of women that only filled out the questionnaire (11.5\%), this potential bias may be limited.

The mean age of women who did not attend the follow-up visit was higher compared to the women who attended the follow-up visit. In our study, age was not a significant risk factor for recurrence of cystocele. Therefore, we don't expect this difference in age to influence our results importantly. If younger age is a risk factor for POP recurrence, as stated by others $(3,25,29)$, our recurrence rate might be an overestimate.

Another limitation of our study was the heterogeneous mix of procedures. However, the performed concomitant procedures are common in normal clinical practice. Therefore, we can state that this study set-up meets daily practice. Our population was predominantly Caucasian, limiting the generalizability of our findings to Caucasian women.

In conclusion, anatomical recurrence of cystocele after anterior colporrhaphy is high, while subjective recurrences occur less frequently. No significant correlation was found between anatomical recurrence and subjective feeling of recurrence. Risk factors for anatomical recurrence are complete avulsion of puborectalis muscle, advanced stage cystocele preoperatively, family history of prolapse, and sacrospinous fixation. 


\section{References}

1. Olsen AL, Smith VJ, Bergstrom JO, Colling JC, Clark AL. Epidemiology of surgically managed pelvic organ prolapse and urinary incontinence. Obstet Gynecol 1997;89:501-506.

2. Hendrix SL, Clark A, Nygaard I, Aragaki A, Barnabei V, McTiernan A. Pelvic organ prolapse in the Women's Health Initiative: gravity and gravidity. Am J Obstet Gynecol 2002;186:1160-1166.

3. Miedel A, Tegerstedt G, Morlin B, Hammarstrom M. A 5-year prospective follow-up study of vaginal surgery for pelvic organ prolapse. Int Urogynecol J Pelvic Floor Dysfunct 2008;9:1593-1601.

4. Progetto Menopausa Italia Study Group. Risk factors for genital prolapse in non-hysterectomized women around menopause. Results from a large cross-sectional study in menopausal clinics in Italy. Eur J Obstet Gynecol Reprod Biol 2000;93:135-140.

5. Amselem C, Puigdollers A, Azpiroz F, Sala C, Videla S, Fernandez-Fraga X et al. Constipation: a potential cause of pelvic floor damage? Neurogastroenterol Motil 2009;22:150-153.

6. Moalli PA, Jones Ivy S, Meyn LA, Zyczynski HM. Risk factors associated with pelvic floor disorders in women undergoing surgical repair. Obstet Gynecol 2003;101:869-874.

7. Chiaffarino F, Chatenoud L, Dindelli M, Meschia M, Buonaguidi A, Amicarelli F et al. Reproductive factors, family history, occupation and risk of urogenital prolapse. Eur J Obstet Gynecol Reprod Biol 1999;82:63-67.

8. McLennan MT, Harris JK, Kariuki B, Meyer S. Family history as a risk factor for pelvic organ prolapse. Int Urogynecol J Pelvic Floor Dysfunct 2008;19:1063-1069.

9. Kim CM, Jeon MJ, Chung DJ, Kim SK, Kim JW, Bai SW. Risk factors for pelvic organ prolapse. Int J Gynaecol Obstet 2007;98:248-251.

10. Mant J, Painter R, Vessey M. Epidemiology of genital prolapse: observations from the Oxford Family Planning Association Study. Br J Obstet Gynaecol 1997;104:579-585.

11. Dietz HP. The aetiology of prolapse. Int Urogynecol J Pelvic Floor Dysfunct. 2008;19:1323-1329.

12. DeLancey JO, Kearney R, Chou Q, Speights S, Binno S. The appearance of levator ani muscle abnormalities in magnetic resonance images after vaginal delivery. Obstet Gynecol 2003;101:46-53.

13. Dietz HP, Simpson JM. Levator trauma is associated with pelvic organ prolapse. BJOG 2008;115: 979-984.

14. DeLancey JO, Morgan DM, Fenner DE, Kearney R, Guire K, Miller JM et al. Comparison of levator ani muscle defects and function in women with and without pelvic organ prolapse. Obstet Gynecol 2007;109:295-302.

15. Weemhoff M, Korsten L, Serroyen J, Kampschöer PHNM, Roumen FJME. Postoperative catheterization after anterior colporrhaphy: 2 days versus 5 days. A multicentre randomized controlled trial. Int Urogynecol J 2010;22:477-483.

16. Shumaker SA, Wyman JF, Uebersax JS, McClish D, Fantl JA. Health-related quality of life measures for women with urinary incontinence: the Incontinence Impact Questionnaire and the Urogenital Distress Inventory. Continence Program in Women (CPW) Research Group. Qual Life Res 1994;3:291-306.

17. van der Vaart $\mathrm{CH}$, de Leeuw JR, Roovers JP, Heintz AP. Measuring health-related quality of life in women with urogenital dysfunction: the urogenital distress inventory and incontinence impact questionnaire revisited. Neurourol Urodyn 2003;22:97-104.

18. van Brummen $\mathrm{HJ}$, Bruinse $\mathrm{HW}$, van de Pol G, Heintz $\mathrm{AP}$, van der Vaart $\mathrm{CH}$. Defecatory symptoms during and after the first pregnancy: prevalences and associated factors. Int Urogynecol J Pelvic Floor Dysfunct 2006;17:224-230.

19. Bump RC, Mattiasson A, Bo K, Brubaker LP, DeLancey JO, Klarskov P et al. The standardization of terminology of female pelvic organ prolapse and pelvic floor dysfunction. Am J Obstet Gynecol 1996;175:10-17.

20. Dietz HP. Quantification of major morphological abnormalities of the levator ani. Ultrasound Obstet Gynecol 2007;29:329-334.

21. Dietz HP, Steensma AB. The prevalence of major abnormalities of the levator ani in urogynaecological patients. BJOG 2006;113:225-230.

22. Dietz HP, Bernando MJ, Kirby A, Shek KL. Mimimal criteria for the diagnosis of avulsion of the puborectalis muscle by tomographic ultrasound. Int Urogynecol J 2011;22; 699-704. 
23. Sand PK, Koduri S, Lobel RW, Winkler HA, Tomezsko J, Culligan PJ et al. Prospective randomized trial of polyglactin 910 mesh to prevent recurrence of cystoceles and rectoceles. Am J Obstet Gynecol 2001;184:1357-1362.

24. Dietz HP, Chantarasorn V, Shek K. Levator avulsion is a risk factor for cystocele recurrence. Ultrasound Obstet Gynecol 2010;36:76-80.

25. Diez-Itza I, Aizpitarte I, Becerro A. Risk factors for the recurrence of pelvic organ prolapse after vaginal surgery: a review at 5 years after surgery. Int Urogynecol J Pelvic Floor Dysfunct 2007;18:1317-1324.

26. Ghetti C, Gregory WT, Edwards SR, Otto LN, Clark AL. Pelvic organ descent and symptoms of pelvic floor disorders. Am J Obstet Gynecol 2005;193:53-57.

27. Jeon MJ, Chung SM, Jung HJ, Kim SK, Bai SW. Risk factors for the recurrence of pelvic organ prolapse. Gynecol Obstet Invest 2008;66:268-273.

28. Salvatore $S$, Athanasiou S, Digesu GA, Soligo M, Sotiropoulou M, Serati $M$ et al. Identification of risk factors for genital prolapse recurrence. Neurourol Urodyn 2009;28:301-304.

29. Whiteside JL, Weber AM, Meyn LA, Walters MD. Risk factors for prolapse recurrence after vaginal repair. Am J Obstet Gynecol 2004;191:1533-1538.

30. Smilen SW, Saini J, Wallach SJ, Porges RF. The risk of cystocele after sacrospinous ligament fixation. Am J Obstet Gynecol 1998;179:1465-1471. 


\section{Chapter 4}

\section{Transperineal ultrasound compared to}

evacuation proctography for diagnosing enteroceles and intussusceptions

Weemhoff M, Kluivers KB, Govaert B, Evers JLH, Kessels AGH, Baeten CG Int J Colorectal Dis 2013;28:359-363 


\section{Abstract}

\section{Introduction}

This study concerns the level of agreement between transperineal ultrasound and evacuation proctography for diagnosing enteroceles and intussusceptions.

\section{Methods}

In a prospective observational study, 50 consecutive women who were planned to have an evacuation proctography underwent transperineal ultrasound too. Sensitivity, specificity, positive (PPV) and negative predictive value (NPV) as well as positive and negative likelihood ratio of transperineal ultrasound were assessed in comparison to evacuation proctography. To determine the interobserver agreement of transperineal ultrasound the quadratic weighted kappa was calculated. Furthermore receiver operating characteristic curves were generated to show the diagnostic capability of transperineal ultrasound.

\section{Results}

For diagnosing intussusceptions (PPV 1.00) a positive finding on transperineal ultrasound was predictive of an abnormal evacuation proctography. Sensitivity of transperineal ultrasound was poor for intussusceptions (0.25). For diagnosing enteroceles the positive likelihood ratio was 2.10 and the negative likelihood ratio 0.85 . There are many false positive findings of enteroceles on ultrasonography (PPV 0.29).

The interobserver agreement of the two ultrasonographers assessed as the quadratic weighted kappa of diagnosing enteroceles was 0.44 and of diagnosing intussusceptions was 0.23 .

\section{Conclusions}

An intussusception on ultrasound is predictive for an abnormal evacuation proctography. For diagnosing enteroceles the diagnostic quality of transperineal ultrasound was limited compared tot evacuation proctography. 


\section{Introduction}

An enterocele or intussusception can be suspected in a patient with obstructed defecation, but is often not manifest on physical examination. Physical examination detects only $50 \%$ of enteroceles in women with pelvic organ prolapse (POP) and a visible enterocele on evacuation proctography (1). An intussusception is not easily detected with physical examination. The recognition of an enterocele and intussusception pre-operatively may change the surgical approach in patients presenting with POP and evacuation difficulties. Not identifying enteroceles and intussusceptions is likely to lead to incomplete or ineffective surgical repair. Evacuation proctography is considered the reference standard for diagnosing enteroceles and intussusceptions. Evacuation proctography is uncomfortable for the patient, however, and involves exposure to ionizing radiation. Transperineal ultrasound may be a patient friendly, non expensive, fast and well tolerated alternative to evacuation proctography. The condition for replacing evacuation proctography by transperineal ultrasound is that their diagnostic test characteristics show similar accuracies.

Aim of current study was to determine the level of agreement between transperineal ultrasound and evacuation proctography. Secondarily, the diagnostic test characteristics of transperineal ultrasound for diagnosing enteroceles, rectoceles and intussusceptions were estimated.

\section{Subjects and Methods}

This prospective observational cohort study was performed at the Maastricht University Medical Centre between April 2007 and February 2008. Women with complaints of fecal incontinence or obstructed defecation visiting the tertiary care colorectal pelvic floor unit who were scheduled to undergo a diagnostic endo-anal ultrasonography and evacuation proctography were consecutive asked to join the study. Exclusion criteria for women to join the study were age $<18$ years, legally incapable patients and persons who were not able to understand the information given. The patients included underwent endo-anal ultrasonography, transperineal ultrasonography and evacuation proctography. The observers were blinded to other results (symptoms, physical examination, and other imaging studies). The datasets were anonymized. Due to the fact that the evacuation proctography and endoanal ultrasound examination were planned as part of the diagnostic work up of these patients, only the transperineal ultrasound was an extra intervention. Because the extra burden of transperineal ultrasound recording compared to the burden of the standard care was little this observational study was officially exempted from medical ethical committee approval after consultation of the ethical committee. 
Evacuation proctography was performed using a standardized technique with opacification of the rectosigmoid. Orally liquid barium contrast was given to make the small bowel visible. The vagina was filled with contrast to visualize the vagina. Imaging was performed at rest, during contraction and during straining and evacuation of the contrast. Evaluation of the recorded videos and photos was performed independently by two experienced observers (C.B. and B.G.). Disagreement between assessors was solved at a consensus meeting. Transperineal ultrasound was performed using a GE Kretz Voluson 730 expert system. For transperineal ultrasonography a 4 to $8 \mathrm{mHz}$ transabdominal curved 2D transducer was used. No contrast medium was used. The transducer was placed against the perineum in the midsagittal plane with a maximum angle of 70 degrees. The ultrasound examinations were performed with the patient in the supine position with slightly flexed legs. Patients were requested to empty their bladder prior to the examination. Imaging was acquired at rest, during contraction and during straining. At least three Valsalva maneuvers were recorded as a cineloop and the best of these maneuvers was used for evaluation.

The ultrasound data were assessed independently by two experienced urogynecological ultrasonographers (M.W. and K.K.). After establishing the interobserver agreement between the ultrasonographers a consensus meeting was held on the cases the assessors disagreed about.

A standardized scoring form was used to record the assessments of evacuation proctography and transperineal ultrasound. While for ultrasound there is no standardized method of describing rectoceles and enteroceles we used the same method as was used for proctography to facilitate comparison. All other studies in literature on diagnosing enteroceles and rectoceles with transperineal ultrasound used the same system of evaluation.

Enterocele was defined as a herniation of the peritoneal cavity with abdominal contents between rectum and vagina. Grade 1 enterocele extended into the upper half of the vagina. Grade 2 enterocele reached the perineum and grade 3 enterocele protruded out of the vagina (7).

Rectocele was defined as a bulging of the anterior rectal wall into the vagina. The maximum depth of the bulging rectocele was measured perpendicular to the expected contour of the anterior rectal wall. Grade 1 was a rectocele with a depth below $2 \mathrm{~cm}$. Grade 2 rectocele had a depth between 2 and $4 \mathrm{~cm}$. In a grade 3 rectocele the depth of the bulge exceeded $4 \mathrm{~cm}$ (7).

Intussusception was defined as invagination of the proximal rectal wall during defecation. The presence of an intussusception was dichotomized (present, absent) (7).

To analyze the data the rectoceles diagnosed by evacuation proctography were dichotomized $(<2 \mathrm{~cm},>2 \mathrm{~cm})$. Due to the fact that $81 \%$ of asymptomatic women demonstrates a small rectocele in evacuation proctography, we classified a small rectocele $<2 \mathrm{~cm}$ as normal (8). 
Rectoceles with a depth of $2 \mathrm{~cm}$ or more were classified as clinically relevant (9). Also for enteroceles and intussusceptions the data from evacuation proctography were dichotomized for analysis (present, absent). ROC-curves were constructed for diagnosing rectoceles, enteroceles and intussusceptions by transperineal ultrasound. Evacuation proctography was considered the reference standard.

Statistical analysis was performed using SPSS software package 15.0 for Windows. To determine the interobserver agreement of transperineal ultrasound the quadratic weighted kappa was calculated. Sensitivity, specificity, positive and negative predictive value as well as positive and negative likelihood ratio of transperineal ultrasound was assessed in comparison to evacuation proctography. Furthermore ROC curves have been generated to show the diagnostic capability of transperineal ultrasound.

\section{Results}

Fifty women were included in the study. The mean age was 59 years (range, 28-95). Eighty-two percent ( $82 \%$ ) of women had fecal incontinence and $16 \%$ had complaints of obstructed defecation. Table 4.1 shows the findings in these 50 women on evacuation proctography. Twenty nine of 50 women (58\%) had an evacuation proctography with an abnormality defined as a rectocele $>2 \mathrm{~cm}$, or an enterocele, or an intussusception.

Table 4.1 Findings on evacuation proctography.

\begin{tabular}{lccc}
\hline & $\begin{array}{c}\text { Fecal } \\
\text { incontinence } \\
\mathrm{n}=42\end{array}$ & $\begin{array}{c}\text { Obstructed } \\
\text { defecation } \\
\mathrm{n}=8\end{array}$ & $\begin{array}{c}\text { Total group } \\
\mathrm{n}=50(\%)\end{array}$ \\
\hline Rectocele & & & $31(62)$ \\
Rectocele depth $<2 \mathrm{~cm}$ & 9 & 1 & $10(20)$ \\
Rectocele depth $2-4 \mathrm{~cm}$ & 14 & 3 & $17(34)$ \\
$\quad$ Rectocele depth $>4 \mathrm{~cm}$ & 4 & 0 & $4(8)$ \\
Enterocele & 6 & 0 & $8(16)$ \\
$\quad$ Enterocele into distal half of vagina & 1 & 0 & $6(12)$ \\
$\quad$ Enterocele reaching the perineum & 0 & 1 & $1(2)$ \\
$\quad$ Enterocele protruding from vagina & 16 & 0 & $1(2)$ \\
Intussusception & & & $16(32)$ \\
\hline
\end{tabular}

In Table 4.2 the findings of transperineal ultrasound are compared to the findings of evacuation proctography, the reference standard. In Table 4.3 the prevalence, sensitivity, specificity, positive and negative predictive value and the positive and negative likelihood ratios of transperineal ultrasound compared to evacuation proctography are shown. The ROC curves for transperineal ultrasound are depicted in 
Figure 4.1. The interobserver agreement of the 2 ultrasonographers assessed as the quadratic weighted kappa of diagnosing enteroceles was $0.44(95 \% \mathrm{Cl} 0.08,0.80)$, of diagnosing rectoceles was $0.51(95 \% \mathrm{Cl} 0.27,0.75)$ and of diagnosing intussusceptions was $0.23(95 \% \mathrm{Cl}-0.22,0.69)$.

Table 4.2 Findings on transperineal ultrasound and evacuation proctography.

\begin{tabular}{lllrr}
\hline & & \multicolumn{2}{c}{ Evacuation proctography } \\
\cline { 4 - 5 } & & & Yes & No \\
\hline Rectocele $>2 \mathrm{~cm}$ depth & Transperineal & Yes & 6 & 1 \\
& Ultrasound & No & 15 & 28 \\
Enteroceles & Transperineal & Yes & 2 & 5 \\
\multirow{3}{*}{ Intussusception } & Ultrasound & No & 6 & 37 \\
& Transperineal & Yes & 4 & 0 \\
& Ultrasound & No & 12 & 34 \\
\hline
\end{tabular}

Table 4.3 Diagnostic characteristics of transperineal ultrasound with evacuation proctography as gold standard.

\begin{tabular}{lccc}
\hline & $\begin{array}{c}\text { Rectocele } \\
>2 \text { cm depth }\end{array}$ & Enterocele & Intussusception \\
\hline Prevalence & $42 \%$ & $16 \%$ & $32 \%$ \\
Sensitivity $(95 \% \mathrm{Cl})$ & $0.29(0.11,0.52)$ & $0.25(0.03,0.65)$ & $0.25(0.07,0.52)$ \\
Specificity $(95 \% \mathrm{Cl})$ & $0.97(0.82,0.99)$ & $0.88(0.74,0.96)$ & $1.00(0.90,1.00)$ \\
PPV $(95 \% \mathrm{Cl})$ & $0.86(0.42,0.98)$ & $0.29(0.04,0.71)$ & $1.00(0.40,1.00)$ \\
NPV $(95 \% \mathrm{Cl})$ & $0.65(0.49,0.79)$ & $0.86(0.72,0.95)$ & $0.74(0.59,0.86)$ \\
LR+ $(95 \% \mathrm{Cl})$ & $8.29(1.08,64.0)$ & $2.10(0.49,9.00)$ & $\sim(1.06$ to $)$ \\
LR- $(95 \% \mathrm{Cl})$ & $0.74(0.56,0.98)$ & $0.85(0.56,1.29)$ & $0.75(0.56,0.99)$ \\
\hline
\end{tabular}

$\mathrm{PPV}=$ Positive predictive value, NPV= Negative predictive value, $\mathrm{LR}+=$ Positive Likelihood Ratio, LR- = Negative Likelihood Ratio, $\mathrm{Cl}=$ confidence interval
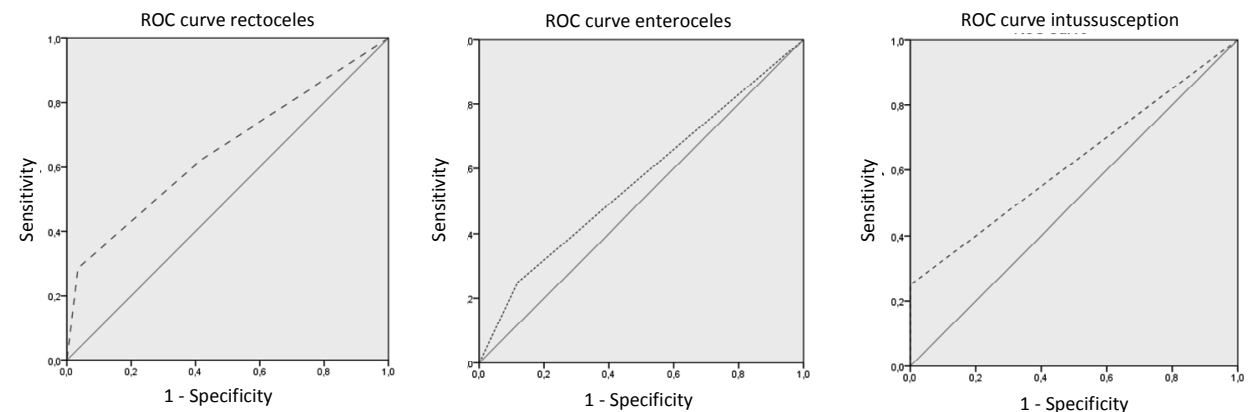

Figure 4.1 ROC curves transperineal ultrasound (evacuation proctography gold standard). 


\section{Discussion}

The aim of the current study was to determine the level of agreement between transperineal ultrasound and evacuation proctography. Secondarily, the diagnostic test characteristics of transperineal ultrasound for diagnosing enteroceles, rectoceles and intussusceptions were estimated as well as interobserver agreement.

For diagnosing rectoceles and intussusceptions, a positive finding on transperineal ultrasound was predictive of an abnormal evacuation proctography. Sensitivity of transperineal ultrasound was poor for both rectoceles and intussusceptions. For diagnosing enteroceles, the positive likelihood ratio was only 2.10 and the negative likelihood ratio only 0.85 . Because there are many false positive ultrasound scans (PPV 0.29) ultrasonography cannot replace evacuation proctography for diagnosing enteroceles.

An important difference between the 2 diagnostic modalities is the position of the patient. In ultrasound, the patient is in supine position and is asked to give a strong Valsalva. On ultrasound, one is able to monitor the Valsalva and to give feedback when the Valsalva is not performed adequately. Evacuation proctography is performed in vertical position with an attempt to defecate the contrast medium. Although the position of the patient is different in the two modalities, these methods are tested as they are used in daily practice and therefore reflect daily care.

The interobserver agreement between ultrasonographers for diagnosing enteroceles and rectoceles was only moderate, and for intussusceptions, it was only fair.

Table 4.4 shows the diagnostic characteristics as found in literature together with the findings of this present study.

\section{Enterocele}

As is shown in Table 4.4, 2 other studies have reported on diagnosing enteroceles with transperineal ultrasound $(2,3)$. Both studies' findings differ significantly from those of our study. Steensma showed in 2010, in a study on 75 women with POP, a positive predictive value of ultrasound of 0.89 . In combination with a positive likelihood ratio of 16 in Steensma's study, transperineal ultrasound renders large conclusive changes from the pre- to posttest probability of enteroceles. Beer-Gabel came to the same conclusions in 2008 in a study on 62 women with obstructed defecation. Based on the findings of these two studies, ultrasound (with a high positive likelihood ratio and a high positive predictive value for the diagnosis of enteroceles) would make evacuation proctography redundant in women with an abnormal ultrasound scan.

Why do these results differ so much from this present study? There are a few differences between the two previous studies and the present one. At first, the prevalence of abnormalities is lower in the present study population. Another important difference is the fact that our study is the only study in which the interpretation of more than one observer has been studied. Taking into account the 
only moderate interobserver agreement for diagnosing enteroceles it can not be expected that ultrasound would perform well.

Table 4.4 Overview of literature comparing diagnostic characteristics of transperineal ultrasound with evacuation proctography as reference standard.

\begin{tabular}{|c|c|c|c|c|c|c|c|}
\hline & Prev & Sens & Spec & PPV & NPV & $\mathrm{LR}+$ & LR - \\
\hline \multicolumn{8}{|l|}{ Enteroceles } \\
\hline Steensma $(2010)^{2}$ & $33 \%$ & 0.64 & 0.96 & 0.89 & 0.84 & 16.0 & 0.38 \\
\hline Beer-Gabel $(2008)^{3}$ & $24 \%$ & 0.80 & 0.96 & 0.86 & 0.73 & 19.0 & 0.21 \\
\hline Present study & $8 \%$ & 0.25 & 0.88 & 0.29 & 0.86 & 2.10 & 0.85 \\
\hline \multicolumn{8}{|l|}{ Rectoceles } \\
\hline Steensma $(2010)^{2}$ & $48 \%$ & 0.78 & 0.77 & 0.76 & 0.79 & 3.37 & 0.29 \\
\hline Perniola $(2008)^{5}$ & $71 \%$ & 0.64 & 0.67 & 0.82 & 0.43 & 1.91 & 0.55 \\
\hline Grasso $(2007)^{4}$ & $86 \%$ & 0.78 & 0.83 & 0.97 & 0.38 & 4.70 & 0.26 \\
\hline Present study & $42 \%$ & 0.29 & 0.97 & 0.86 & 0.65 & 8.29 & 0.74 \\
\hline \multicolumn{8}{|l|}{ Intussusception } \\
\hline Steensma $(2010)^{2}$ & $36 \%$ & 0.22 & 0.96 & 0.75 & 0.69 & 5.33 & 0.81 \\
\hline Perniola $(2008)^{5}$ & $78 \%$ & 0.30 & 0.86 & 0.88 & 0.27 & 2.13 & 0.81 \\
\hline Grasso $(2007)^{4}$ & $51 \%$ & 0.91 & 1.00 & 1.00 & 0.91 & 99999 & 0.09 \\
\hline Present study & $32 \%$ & 0.25 & 1.00 & 1.00 & 0.74 & 99999 & 0.75 \\
\hline
\end{tabular}

Prev $=$ Disease prevalence in study population, Sens $=$ Sensitivity, Spec $=$ Specificity, PPV= Positive predictive value, NPV= Negative predictive value, $L R+=$ Positive Likelihood Ratio, LR-= Negative Likelihood Ratio

\section{Rectocele}

Regarding rectoceles, 3 further studies have been published $(2,4,5)$. All 3 , as well as our study, concluded that the finding of a rectocele on ultrasound is highly predictive for a rectocele on evacuation proctography. With regard to clinical practice, the relevance of imaging a rectocele is limited because most rectoceles are diagnosed by physical examination (1). Especially since $81 \%$ of asymptomatic women have a rectocele, physical examination is always combined with questions on complaints of a lump or dragging sensation (7). In women with a hysterectomy in history, imaging might be helpful by distinguishing a rectocele from an enterocele.

\section{Intussusception}

Intussusception on perineal ultrasound is highly predictive of an abnormal evacuation proctography. All available studies show the combination of a high positive likelihood ratio and a high positive predictive value for diagnosing intussusception on perineal ultrasound. However, sensitivity of ultrasound for diagnosing intussusception is rather low, and abnormalities may be missed on ultrasound. 
There are weaknesses in our study. The prevalence of enteroceles was low in our population. All patients with an enterocele were considered to be abnormal, including the very small ones. Out of 8 enteroceles in our population only 2 descended until halfway the vaginal length, the others were less pronounced. However all other studies applied the same cut off value as we did. The prevalence of enteroceles in our study population (16\%) was comparable to the prevalence of enteroceles in a population of women with POP (1).

Future studies are needed to study the diagnostic capacities of transperineal ultrasound to confirm or disapprove our findings. Based on the findings in our present study, it is of pivotal importance to include more than one observer in future studies. In conclusion, an abnormal transperineal ultrasound scan showing a rectocele or intussusception is predictive of an abnormal evacuation proctography, but has low sensitivity. For diagnosing enteroceles, in the present study with more than one observer, the diagnostic quality of transperineal ultrasound was limited compared to evacuation proctography. Transperineal ultrasound can not replace evacuation proctography for diagnosing enteroceles and intussusceptions. 


\section{References}

1. Kelvin FM, Hale DS, Maglinte DDT, Patten BJ, Benson JT. Female pelvic organ prolapse: diagnostic contribution of dynamic cystoproctography and comparison with physical examination. AJR 1999;173:31-37.

2. Martellucci J, Naldini G. Clinical relevance of transperineal ultrasound compared with evacuation proctography for the evaluation of patients with obstructed defaecation. Colorectal Dis 2011;13:1167-1172.

3. Steensma AB, Ooms DMJ, Burger CW, Schouten WR. Assessment of posterior compartment prolapse: a comparison of evacuation proctography and $3 \mathrm{D}$ transperineal ultrasound. Colorectal Disease 2010;12:533-539.

4. Beer-Gabel M, Assoulin Y, Amitai M, Bardan E. A comparison of dynamic transperineal ultrasound (DTP-US) with dynamic evacuation proctography (DEP) in the diagnosis of cul de sac hernia (enterocele) in patients with evacuatory dysfunction. Int J Colorectal Dis 2008;23:513-519.

5. Grasso RF, Picuicchi S, Quattrocchi CC, Sammarra M, Ripetti V, Beomonte Zobel B. Posterior pelvic floor disorders: a prospective comparison using introital ultrasound and colpocystodefecography. Ultrasound Obstet Gynecol 2007;30:86-94.

6. Perniola G, Shek C, Chong CCW, Chews S, Cartmill J, Dietz HP. Defecation proctography and translabial ultrasound in the investigation of defecatory disorders. Ultrasound Obstet Gynecol 2008;31:567-571.

7. Dobben AC, Wiersma TG, Janssen LWM, de Vos R, Terra MP, Baeten CG, Stoker J. Prospective assessment of interobserver agreement for defecography in fecal incontinence. AJR 2005;185:1166-1172.

8. Shorvan PJ, Mc Hugh S, Diamant NE, Somers S, Stevenson GW. Defecography in normal volunteers: results and implications. Gut 1989;30:1737-1749.

9. Ghetti C, Gregory WT, Edwards SR, Otto LN, Clark AL. Pelvic organ descent and symptoms of pelvic floor disorders. Am J Obstet Gynecol 2005;193:53-57. 


\section{Chapter 5}

\section{Optimizing the image quality of pelvic floor ultrasound}

\section{Based on}

Optimizing the 2D and 3D imaging quality of pelvic floor ultrasound Weemhoff M, Notten K, Kluivers KB, Hoeks APG, Kessels AGH, Evers JLH, Kruitwagen RFPM1, Hoogland HJ 


\section{Abstract}

Aim

To identify which GE Kretz Voluson 730 ultrasound machine settings result in the best quality images in pelvic floor ultrasound imaging.

\section{Methods}

In a pilot study in one healthy nulligravid volunteer a 2D pelvic floor ultrasound scan was performed and 84 images were obtained of different ultrasound machine settings. Two observers assessed these images for quality and ordered the images. Linear regression was performed to determine which ultrasound machine settings are of most importance for quality. In the second part of the study 5 observers assessed 2D and 3D pelvic floor ultrasound images for quality in 5 healthy nulligravid volunteers. Eight images per volunteer were presented at random to the observers who were instructed to order the images according to perceived quality. Linear and logistic regression was performed, ROC curves were made and intraclass correlation between observers was calculated. For statistical analysis SPSS was used.

\section{Results}

The pilot study showed speckle reduction imaging (SRI), harmonic imaging ( $\mathrm{HI}$ ) and cross beam compound resolution imaging (CRI) to be significantly important for perceived quality.

The ultrasound machine settings used for the three best images of the eight images per volunteer were analyzed. In the 2D mode the area under the curve (AUC) in the receiver operating curve (ROC) was $0.845,0.609$, and 0.592 for $\mathrm{SRI}, \mathrm{HI}$ and $\mathrm{CRI}$, respectively. Best quality 2D images were obtained using the combination of SRI, CRI and HI (AUC=0.914). In the 3D mode, the AUC of the SRI alone was 0.913, while SRI in combination with the CRI and HI yielded an AUC of 0.987.

\section{Conclusions}

Speckle reduction (SRI) is the single most important software application for optimizing the imaging quality of pelvic floor ultrasound in both 2D and 3D mode. Adding $\mathrm{HI}$ and CRI slightly improves image quality. 


\section{Introduction}

Pelvic floor ultrasound imaging has been described in the literature extensively since the year 2000. The 2D mode is used for visualizing the pelvic floor muscles, the pubic bone, bladder, urethra, rectum, anal canal, uterus or vaginal vault. The ultrasound scan can be recorded as a cineview while the patient is contracting the pelvic floor, while she is performing a Valsalva maneuver or while she is coughing. In the 2D mode one can study the pelvic floor position and function (coordination), and mobility of different pelvic organs. In the 3D mode the integrity of levator ani muscle and the hiatal area as well as the influence of Valsalva and contraction on the levator muscle configuration and hiatal area can be visualized.

The details of the information that can be obtained from these ultrasound scans vary with the machine and the settings that have been used. Figure 5.1 shows $2 D$ and 3D images that are obtained with pelvic floor ultrasound. Dietz et al. published a monograph on pelvic floor ultrasound, containing a chapter on the technological aspects of pelvic floor ultrasound (1). In that chapter different software applications in use were reviewed. However, no details were given to select the best application for 2D or 3D mode. To the best of our knowledge no studies have yet been published on the equipment settings that matter in pelvic floor ultrasound.

Speckle reduction imaging (SRI) is a technique which reduces speckle resulting from an intrinsic artifact. Speckle is created by a complex interference of ultrasound echoes made by reflectors spaced closer together than the resolution of the ultrasound system. SRI is an image processing application that involves an analysis phase in which artifacts and targets are identified and an enhancement phase in which artifacts are suppressed and targets enhanced. The relative difference between neighboring pixel values is examined to determine whether the gray scale variations have a sharp transient, follow a trend, or are random in nature. Random variations are classified as artifacts. Processed image data are then combined to reconstruct the entire image $(2,3)$.

Harmonic imaging (HI) suppresses the ultrasonic signal at the fundamental frequency to view only the higher frequency harmonic of a signal. As high amplitude ultrasound passes through tissue, it is subjected to non-linear distortion, creating higher harmonics. Because higher harmonics are more attenuated, reverberation artifacts are less likely, resulting in a clearer image (4). Moreover, the harmonics are predominantly generated within the central region of the ultrasound beam, contributing to a better lateral resolution.

Cross beam compound resolution imaging (CRI) is a mode in which pulses are transmitted alternating perpendicularly to the acoustic window and in oblique directions. The summed images (compounding) include structures viewed from various directions and consequently exhibit enhanced contrast resolution with better tissue differentiation and clearer organ borders (5). 
Most commercially available systems support these techniques although the acronym and implementation may vary with the manufacturer.

The current study focuses on identifying the settings of an ultrasound machine that are relevant for optimizing the quality and information that can be obtained from pelvic floor ultrasound scans.

\section{General methods}

\section{Ultrasound examination}

The ultrasound examination in this study was performed with the participant in the supine position with slightly flexed legs. No opacification of structures was performed. In the 2D mode in the midsagittal plane 4 references had to be visualized in one frame: the symphysis, the urethra, the anal canal and the levator ani muscle. (Figure 5.1)

The ultrasound machine used in this study was the GE Kretz Voluson 730 expert (Zipf, Austria). The 2D ultrasound image was produced using a transabdominal probe with an angle of view of 70 degrees with 2 focus points, a depth of $8 \mathrm{~cm}$, and a frequency range of 3.3-6.6 $\mathrm{MHz}$. In each scan the emission power was kept as low as reasonably achievable and was adjusted to the amount of acoustic output.

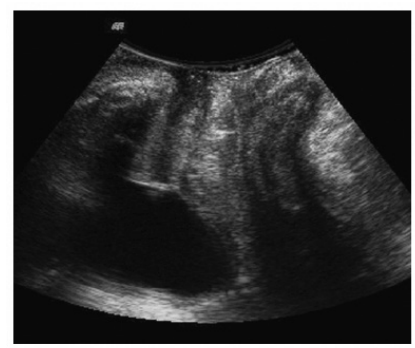

SRI off, HI off, CRI off

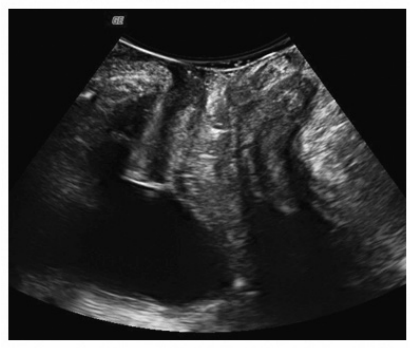

SRI 6, HI off, CRI off

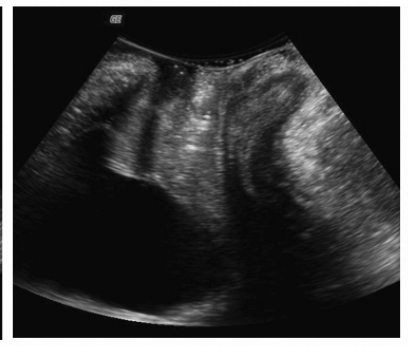

SRI off, HI off, CRI 8 high

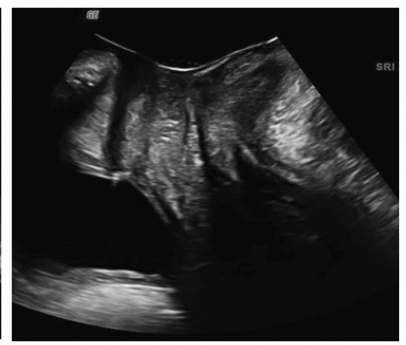

SRI 6, HI high, CRI 8 high

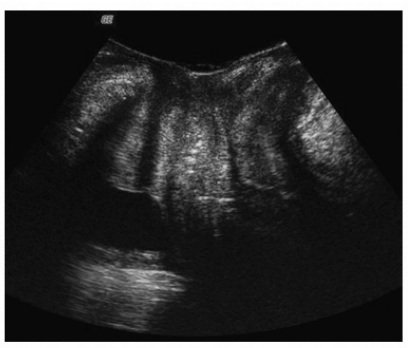

SRI off, HI high, CRI off

Figure 5.1 Five examples of the 84 settings.

In each image the midsagittal plane is visualized with symphysis, urethra, anal canal, and puborectal muscle. 


\section{Methods, results and interim conclusion part 1, pilot study}

\section{Methods part 1, pilot study}

A pilot study was performed to identify the settings which were expected to have significant impact on the quality of pelvic floor ultrasound scans. In this pilot study, a pelvic floor ultrasound examination was performed in one healthy nulligravid volunteer using a range of settings on the ultrasound machine resulting in 84 different ultrasound images. Two observers arranged the images in order of perceived quality, independently from the others. Afterwards the 2 observers reached consensus on the order quality of the images. The size of the images and the voxel density was the same for each image. The best quality was defined as the image where the different structures, bone, muscle, and blood vessel were most easily recognized and the borders between structures were the most clear. The 2 observers were blinded for the settings of the ultrasound machine.

The settings that were studied in this pilot study were speckle reduction imaging (SRI), harmonic imaging ( $\mathrm{HI}$ ) and cross beam compound resolution imaging (CRI). The settings SRI off, SRI 3, SRI 6, HI off, HI low, HI mid, HI high, CRI off, CRI 4 low, CRI 4 mid, CRI 4 high, CRI 8 low, CRI 8 mid, and CRI 8 high were considered, giving 84 images. (examples Figure 5.1)

Statistical analysis of the settings was performed with a linear regression model with the setting as independent and the quality score as dependent variable.

SPSS version 20 statistical software for windows was used for statistical analysis.

\section{Results part 1, pilot study}

Table 5.1 shows the results of the linear regression analysis of the ultrasound machine settings determining the order of perceived quality by the 2 observers of 84 images. The quality of 2D pelvic floor ultrasound images is significantly determined by the SRIsetting, the $\mathrm{HI}$ setting and the CRI setting. The regression coefficient of SRI is stronger (37.4) compared to the coefficients of the other settings (13.4 and 13.9).

Table 5.1 Linear regression of factors determining the order of quality of $2 \mathrm{D}$ pelvic floor ultrasound.

\begin{tabular}{lccc}
\hline & $\mathrm{B}$ & $\mathrm{p}$ & $95 \% \mathrm{Cl}$ \\
\hline $\mathrm{SRI}$ on & 37.4 & $<0.01$ & $30.4,44,4$ \\
$\mathrm{HI}$ on & 13.9 & $<0.01$ & $6.3,21.5$ \\
$\mathrm{CRI}$ on & 13.4 & $<0.01$ & $4.0,22.8$ \\
\hline
\end{tabular}

$B=$ regression coefficient; $p=$ level of significance; $\mathrm{Cl}=$ confidence interval 


\section{Interim conclusion part 1, pilot study}

Speckle reduction imaging is the most important for quality of pelvic floor ultrasound in $2 \mathrm{D}$ mode. $\mathrm{HI}$ and $\mathrm{CRI}$ improve the quality furthermore in the $2 \mathrm{D}$ mode.

\section{Methods and results, part 2}

\section{Methods part 2}

Following the pilot study an observational study was performed to identify the settings that optimize the quality of 2D and 3D pelvic floor ultrasound scans. Five volunteers were approached and gave informed consent to be included in the study. In the 5 participants on ultrasound examination all on/off options of SRI, $\mathrm{HI}$, and CRI were combined, resulting in $82 \mathrm{D}$ and $83 \mathrm{D}$ images per volunteer. The $2 \mathrm{D}$ and $3 \mathrm{D}$ images were shown to a panel of 5 observers. Each of the 5 observers arranged the images in decreasing order of perceived quality, independently from the others. The size of the images and the voxel density was the same for each image. The best quality was defined in the same way as in the pilot study as the image where the different structures, bone, muscle, and blood vessel were most easily recognized and the borders between structures were the most clear. The observers were blinded for the settings of the ultrasound machine.

The 5 observers in the study were 2 experts on ultrasonography and 3 gynecologists using ultrasonography in daily practice with no theoretical and technical background of ultrasonography.

Statistical analysis of the settings was performed with a mixed linear regression model with the setting as independent variable and the mean quality score as dependent variable. Defining a quality score $\leq 3$ as good quality (the 3 best images of 8 images per patient), the influence of the settings on this dichotomized quality score was investigated with receiver operating curves (ROC). Additionally, combinations and interaction of settings were investigated with a logistic regression model.

To evaluate the agreement between the observers in the scoring, the intraclass correlation coefficient with $95 \%$ confidence interval (ICC $95 \% \mathrm{Cl}$ ) was calculated. ICC values under 0.2 were considered as poor; between 0.21-0.40 as fair; between $0.41-0.60$ as moderate; between $0.61-0.80$ as good; and between $0.81-1.00$ as excellent agreement between observers (6). SPSS version 20 statistical software for windows was used for statistical analysis. 


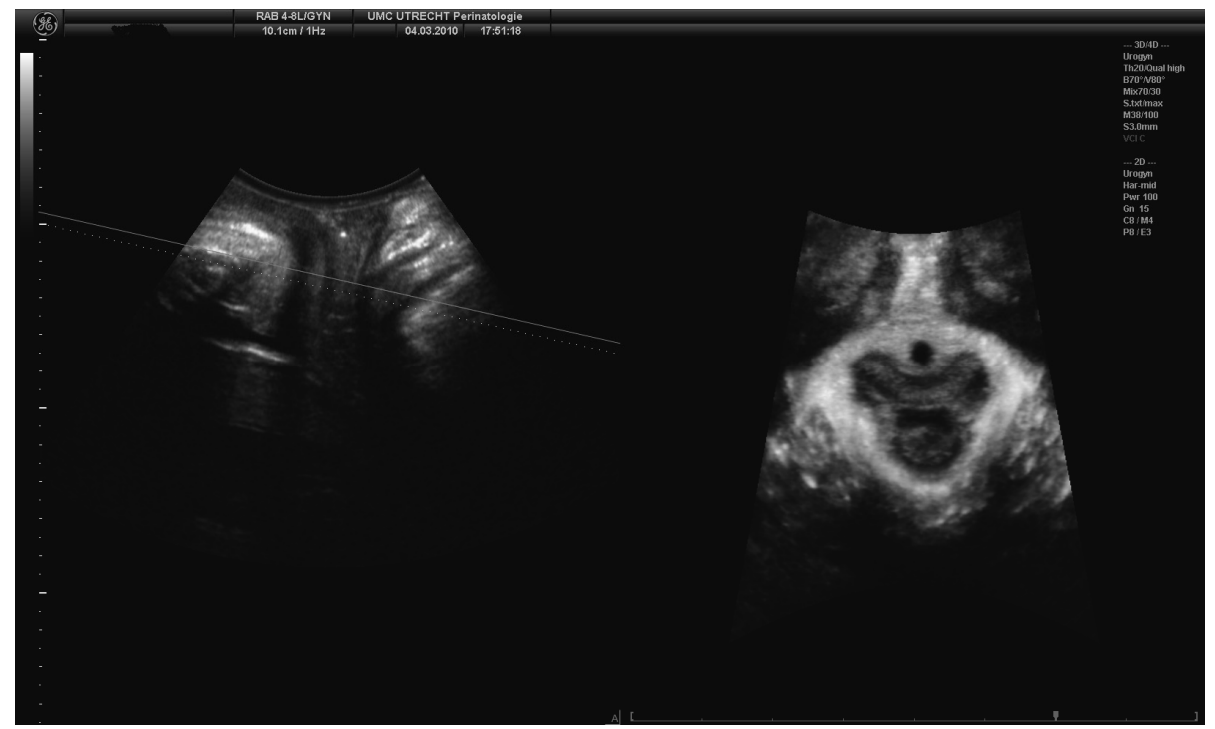

Figure 5.2 3D ultrasonography of pelvic floor

2- and 3-dimensional ultrasonography of pelvic floor. The right image shows the midsagittal plane with symphysis, urethra, anal canal, puborectal muscle. The left image shows the rendered 3D volume of the levator ani muscle (axial plane).

\section{Results part 2}

All 5 participants had a normal BMI (20-25). Table 5.2 shows the results of the linear regression analysis of the factors determining the best mean quality of 2D pelvic floor ultrasound. The SRI setting is highly important for good quality next to a smaller but significant contributing effect of $\mathrm{HI}$ and $\mathrm{CRI}$. Adding $\mathrm{CRI}$ to SRI further improves quality even more. There is no interaction between $\mathrm{HI}$ and SRI, or $\mathrm{HI}$ and CRI. By introducing patient and observer as a factor in a mixed model, no significant interaction is apparent between these factors and the settings of best mean quality. Figure 5.3 shows the ROC curves, illustrating the relative contribution of the various factors to the quality of ultrasound images. The area under the curve (AUC) of the setting in which SRI, HI and CRI are turned on simultaneously is a fraction greater than for SRI only (Table 5.3). 
Table 5.2 Linear regression of factors determining the best mean quality of $2 \mathrm{D}$ pelvic floor ultrasound scored by 5 observers in 5 healthy volunteers

\begin{tabular}{|c|c|c|c|}
\hline & B & $p$ & $95 \% \mathrm{Cl}$ \\
\hline SRI & 2.17 & $<0.01$ & $1.48,2.92$ \\
\hline $\mathrm{HI}$ & 0.74 & 0.01 & $0.22,1.26$ \\
\hline CRI & 0.84 & 0.03 & $0.10,1.57$ \\
\hline Interaction SRI * CRI & 1.12 & 0.04 & $0.07,2.16$ \\
\hline
\end{tabular}

$B=$ regression coefficient; $p=$ level of significance; $C l=$ confidence interval; $S R I=$ speckle reduction imaging; $\mathrm{HI}=$ harmonic imaging; $\mathrm{CRI}=$ cross beam compound resolution imaging

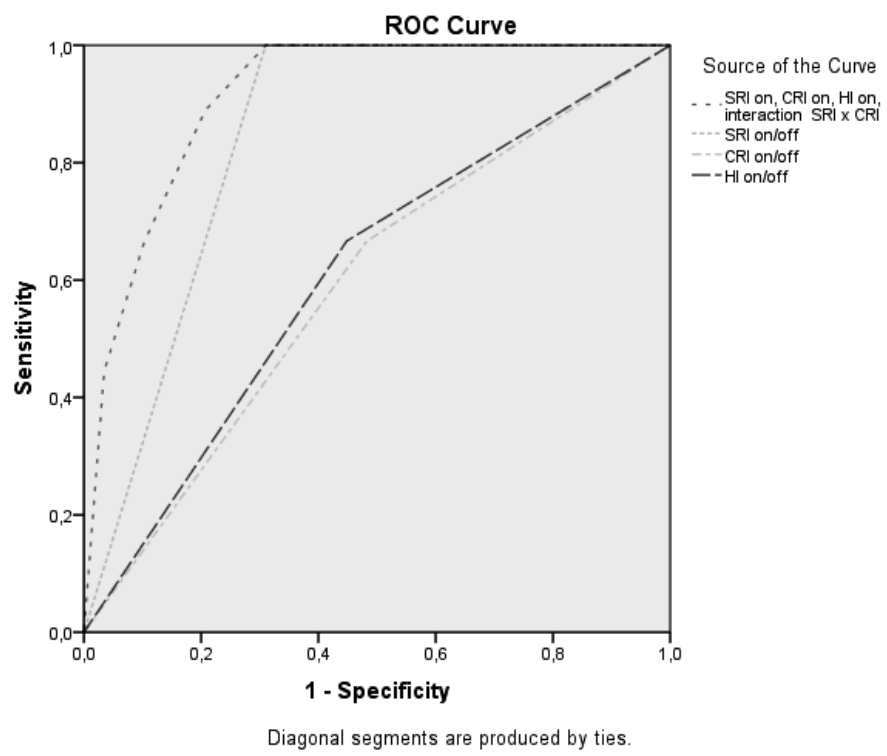

Figure 5.3 ROC curve of the significant settings determining best mean quality of $2 \mathrm{D}$ pelvic floor ultrasound in 5 healthy volunteers scored by 5 observers

$\mathrm{SRI}=$ speckle reduction imaging; $\mathrm{HI}=$ harmonic imaging; $\mathrm{CRI}=$ cross beam compound resolution imaging 
Table 5.3 Area under the curve of the ROC curves of different settings in 2D pelvic floor ultrasound

\begin{tabular}{ll}
\hline Ultrasound setting & AUC \\
\hline SRI on, CRI on, HI on, interaction SRI x CRI & 0.914 \\
SRI on & 0.845 \\
CRI on & 0.592 \\
HI on & 0.609 \\
\hline
\end{tabular}

$\mathrm{SRI}=$ speckle reduction imaging; $\mathrm{HI}=$ harmonic imaging; $\mathrm{CRI}=$ cross beam compound resolution imaging; $A \cup C=$ area under the curve

Table 5.4 shows the regression coefficients of the different factors contributing to the best mean quality of the $3 \mathrm{D}$ pelvic floor ultrasound images. The most important setting in the $3 \mathrm{D}$ mode is the SRI, similar to the 2D mode. With SRI on, turning on either CRI or $\mathrm{HI}$ separately has a minor effect, but the combination of $\mathrm{HI}$ and CRI turned on exhibits a strong interaction with a significant effect on the quality of the images. In the 3D mode there is no interaction between SRI and HI or SRI and CRI. The ROC curve in Figure 5.4 illustrates this finding. Similar to the 2D mode, the area under the curve in the 3D mode of the setting in which SRI, HI and CRI are turned on simultaneously is also a fraction greater than using the SRI alone (Table 5.5).

The excellent interobserver agreement of the 5 observers for scoring the quality of the ultrasound images is reflected by an intraclass correlation coefficient (ICC) of $0.873(95 \% \mathrm{Cl} 0.80,0.93)$ in the $2 \mathrm{D}$ mode and by an ICC of $0.851(95 \% \mathrm{Cl} 0.76,0.92)$ in the 3D mode.

Table 5.4 Linear regression of significant factors determining the best mean quality of 3D pelvic floor ultrasound scored by 5 observers in 5 healthy volunteers

\begin{tabular}{|c|c|c|c|}
\hline & $B$ & $p$ & $95 \% \mathrm{Cl}$ \\
\hline$\overline{S R I}$ & 2.30 & $<0.01$ & $1.60,3.01$ \\
\hline $\mathrm{HI}$ & 0.10 & 0.84 & $-0.87,1.07$ \\
\hline CRI & 0.09 & 0.86 & $-0.91,1.09$ \\
\hline Interaction $\mathrm{CRI} * \mathrm{HI}$ & 1.76 & 0.02 & $0.35,3.17$ \\
\hline
\end{tabular}

$B=$ regression coefficient; $p=$ level of significance; $C l=$ confidence interval; $S R I=$ speckle reduction imaging; $\mathrm{HI}=$ harmonic imaging; $\mathrm{CRI}=$ cross beam compound resolution imaging 


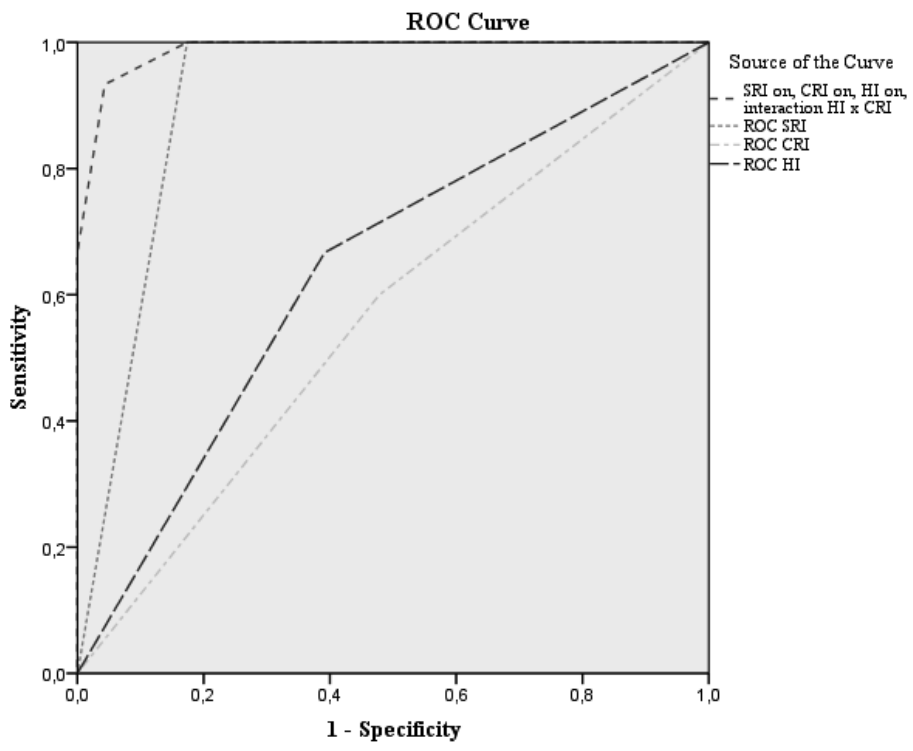

Figure 5.4 ROC curve of the significant settings determining best mean quality of 3D pelvic floor ultrasound in 5 healthy volunteers scored by 5 observers .

$\mathrm{SRI}=$ speckle reduction imaging; $\mathrm{HI}=$ harmonic imaging; $\mathrm{CRI}=$ cross beam compound resolution imaging

Table 5.5 Area under the curve of the ROC curves of different settings in 3D pelvic floor ultrasound

\begin{tabular}{ll}
\hline Ultrasound setting & AUC \\
\hline SRI on, CRI on, HI on, interaction SRI x HI & 0.987 \\
SRI on & 0.913 \\
CRI on & 0.561 \\
HI on & 0.638 \\
\hline
\end{tabular}

$\mathrm{SRI}=$ speckle reduction imaging; $\mathrm{HI}=$ harmonic imaging; $\mathrm{CRI}=$ cross beam compound resolution imaging; $A \cup C=$ area under the curve

\section{Discussion}

Speckle reduction imaging (SRI) is the most important setting for quality of pelvic floor ultrasound in both the 2D and 3D mode. Without this software application the ultrasound scans were mostly scored as suboptimal. The contributing effect of $\mathrm{HI}$ and $\mathrm{CRI}$ is apparent but of minor importance compared to that of SRI. In the 3D mode the separate effects of $\mathrm{HI}$ and $\mathrm{CRI}$ are limited but, because of the strong interaction between $\mathrm{HI}$ and $\mathrm{CRI}$, the effect of turning on both $\mathrm{HI}$ and $\mathrm{CRI}$ is more than the sum of 
their separate effects. A similar amplification effect is observed in 2D mode for the interaction between SRI and CRI

Although there was a difference in background and ultrasound experience between the 5 observers, there was no interaction between the observer and the mean score for a certain method. This means that they had the same opinion regarding good quality images. The agreement among the observers on the scoring of the quality was excellent as is reflected by the ICC values.

Speckle is a disturbing phenomenon in ultrasound imaging. Both smoothing and CRI contribute to speckle reduction techniques. Smoothing works best for structures that in either direction are relatively large with respect to the resolution while compound imaging also suppresses speckle artifacts for small objects. $\mathrm{HI}$ contributes both to noise suppression and improvement of the resolution, mainly in the transversal directions. It is, therefore, not surprising that in 2D images the quality effects of SRI and CRI are correlated and the combined activation of SRI and CRI has an amplifying effect. Similarly $\mathrm{HI}$ improves resolution with a strong effect in the transversal direction where focusing is limited. Though CRI works within the image plane, the reduction in speckle size has direct consequences for the cross-sectional image, explaining the strong correlation between $\mathrm{CRI}$ and $\mathrm{HI}$.

A possible weakness in our study is that we tested the settings in healthy nulligravid volunteers with a normal BMI (20-25). The patient herself was no significant factor in the mean scored image quality. However obesity or an advanced pelvic organ prolapse may influence the choice of the setting to obtain best quality. Nevertheless, it is appropriate to start pelvic floor ultrasound imaging with a uniform setting and subsequently adjust the setting to reach the best individual appearance.

A second weakness of our study was the determination of the overall image quality by ranking, and not by quantification of the different aspects of quality. The best quality was defined as the image where the various structures, bone, muscle, and blood vessel were easiest recognizable and the borders between structures were the most clear.

In conclusion, SRI is the most important software application for optimizing the imaging quality of pelvic floor ultrasound in both the 2D and $3 \mathrm{D}$ mode. $\mathrm{HI}$ and CRI improve the image quality in the 2D mode even more. In the 3D mode image quality is improved by turning on both $\mathrm{HI}$ and $\mathrm{CRI}$, whereas separately these settings have only a limited effect. 


\section{References}

1. Dietz HP, Hoyte LPX, Steensma AB. Atlas of pelvic floor ultrasound. Springer-Verlag London Limited 2008 ISBN 978-1-84628-520-2.

2. Milkowski A, Li Y, Becker D, Ishrak S. Speckle reduction imaging. Ultrasound, GE Medical Systems.

3. Powers J, Kremkau F. Medical ultrasound systems. Review. Interface focus 2011.

4. Tranquart F, Grenier N, Eder V, Pourcelot L. Clinical use of ultrasound tissue harmonic imaging. Ultrasound in Med \& Biol. 1999;25:889-894.

5. Steininger J, Janowski J. High performance 2D imaging. Ultrasound, GE Medical Systems.

6. Bland JM, AltmanDG. Statistical methods for assessing agreement between two methods of clinical measurements. Lancet 1986; 1: 307-310. 


\section{Chapter 6 \\ Comparison of two scoring systems for diagnosing levator ani muscle damage}




\section{Abstract}

\section{Introduction}

Levator defects are risk factors for pelvic organ prolapse (POP) and its recurrence. The most widely used scoring systems for severity of defects shown on MRI and perineal ultrasound are not identical. The aim of this study was to investigate the differences between these classification systems with regard to levator defects on ultrasound and their clinical relevance for recurrence after prolapse surgery.

\section{Methods}

Women with previous cystocele repair underwent transperineal 3D ultrasound. Levator defects were graded according to the scoring system described with regard to MRI (Delancey et al.) and perineal ultrasound (Dietz et al.). The results were compared using the weighted kappa and receiver operating characteristic (ROC) curves (SPSS version 20.0).

\section{Results}

We assessed 152 women. On ultrasound classification more defects were categorized as highest grade compared with MRI classification [ $n=64(42 \%)$ versus $n=41(28 \%), p<0.01]$. The grades of levator defects on both scoring systems showed very good agreement with a weighted kappa of 0.82 [95\% Confidence interval $(\mathrm{Cl}), 0.75,0.88$ ]. The predictive value of scoring systems for cystocele recurrence after prolapse surgery showed an area under the ROC curve (AUC) of 0.63 and 0.64 , respectively.

\section{Conclusions}

Comparison of the 2 scoring systems showed good agreement, but was lowest for the highest grade defects. There was no difference in predictive value between scoring systems for cystocele recurrence after prolapse surgery. 


\section{Introduction}

Trauma to the levator ani muscle after vaginal delivery has shown to be a risk factor for POP (1) and its recurrence $(2,3)$. Computer modeling based on MRI has shown that the most inferior and medial parts of the levator ani must increase in length by a factor of 3.5 during crowning of the fetal head during vaginal delivery (4). An ultrasound study concerning the degree of stretch of the levator hiatus in childbirth on 227 women showed great variations. The dimensions of the hiatal area at maximal Valsalva in some women appear to distend only $25 \%$ but in others have to distend $245 \%$ (5). After vaginal delivery, detachment of these inferomedial aspects of the levator ani from its insertion on the pelvic sidewall may occur $(6,7)$. In studies using MRI and ultrasound, levator trauma was identified in about $13-20 \%$ of women delivered vaginally (8). Shek et al. diagnosed $17 \%$ of women 6 months postpartum who delivered vaginally as having levator macrotrauma on ultrasound examination (9).Levator defects can be detected by digital vaginal palpation, MRI and pelvic floor ultrasound. A levator defect can be partial, with residual connection of the levator muscle to the pubic bone, or total, without connection and complete architectural distortion of the levator hiatus.

Different classifications of levator ani muscle damage are used in studies using MRI and ultrasound as imaging methods. Delancey et al. classified levator damage as major, minor or none using MRI $(10,11)$. This classification system showed good interrater reliability (12). Dietz et al. described a classification for 3D transperineal ultrasound on which a levator defect is classified as complete, partial or no avulsion (13). This classification system has also shown good interrater reliability (14). The main difference between the 2 scoring systems is that Delancey et al. focus on the mean percentage of missing muscle, whereas Dietz et al. count the number of slices in a tomographic imaging technique showing a defect $(10,13)$.

Distinguishing major levator defects from minor or no levator defects is of clinical relevance because the development of POP was not associated with minor levator defects on MRI and ultrasound but only with a severe grade of levator defects $(10,13)$. There is little comparative research between MRI and 3D ultrasound imaging of the pelvic floor, especially to evaluate levator defects. Two studies showed that there is a good correlation between $\mathrm{MRI}$ and 3D transperineal ultrasound for levator hiatal dimensions $(15,16)$, whereas another study found a moderate to poor correlation (17). These studies have not investigated levator defects. Zhuang et al. published a study comparing 3D ultrasound with MRI for detecting levator defects in 66 patients (18). The 2 imaging methods correlated well. With respect to the extent of the defect (i.e., complete or partial) the correlation showed a kappa of 0.65 [95\% Confidence interval $(\mathrm{Cl}) 0.48,0.83$ ]. In this study ultrasound yielded a higher number of complete avulsions and 3D MRI identified a higher number of partial avulsions.

Direct comparison of studies using MRI with studies using ultrasound for diagnosing levator defects is limited due to different scoring and classification systems. It is not 
clear whether the cutoff between a minor and a severe grade levator defect on ultrasound is identical to the cutoff used in MRI. This hampers the comparison of studies using different imaging modalities and scoring systems.

The aim of the study reported here was to compare MRI and ultrasound classifications of levator defects on pelvic floor ultrasound images. The prediction of cystocele recurrence after 2 years was used to compare which scoring system related best to clinical outcome.

\section{Materials and Methods}

Data on all women who underwent transperineal 3D ultrasonography because of their participation in a follow-up study on risk factors for cystocele recurrence after anterior repair were assessed. (3) Data on patient characteristics were available from the initial follow-up study.

Transperineal ultrasonography of the pelvic floor was performed with the women in the supine position after voiding. A GE Voluson 730 expert system (GE Kretz Ultrasound, Zipf, Austria) was used with an 8-4 $\mathrm{MHz}$ curved-array abdominal volume transducer. An axial 4D volume was rendered at the level of the hiatus of minimal dimensions. In this plane, a 4D volume cine was recorded containing a maximal pelvic muscle contraction to detect abnormal insertion of the puborectalis muscle on the inferior ramus. This method has been described by Dietz et al. and is reproducible $(14,19)$.

The recorded data sets were analyzed offline using Voluson GE Kretz 4D-view V 5.1 software (GE Kretz Ultrasound). Tomographic ultrasound imaging was used to assess the levator ani muscle in multiple slices of $2.5 \mathrm{~mm}$ for each side separately. In the three central slices (i.e., the plane of minimal dimensions plus slices 2.5 and $5 \mathrm{~mm}$ cranial to this plane), levator damage was graded according to the scoring system described in studies using MRI $(10,11)$ and in studies using ultrasound (13), and the levator urethral gap (LUG) was measured. (13). To measure the LUG, calipers were placed in the center of the hypoechogenic structure that indicates the urethral mucosa and smooth muscle and on the most medial aspect of the muscle insertion on the inferior pubic ramus (20). In the 3 central slices, insertion of the levator ani muscle on the pelvic sidewall was rated as normal or abnormal. In doubtful cases, the LUG was used. The insertion was regarded as abnormal when the LUG was $>2.5 \mathrm{~cm}(13,20)$. A complete avulsion was diagnosed when all 3 slices showed an absent connection between the puborectalis muscle and inferior pubic ramus. Partial avulsion was diagnosed only when one or 2 slices showed absent connection. No avulsion was diagnosed when all 3 slices showed integrity. For the final score of each individual, assessments of the 2 sides were combined. If both sides showed no avulsion, it was defined as such. If at least one side was marked as complete avulsion, it was defined as such. In all other cases, a partial avulsion was diagnosed. 
The 3 central slices were scored again by the scoring system described with regard to MRI. If no damage was visible, it was assigned a score of zero; if less than half of the muscle was missing, it was assigned a score of 1 ; if more than half of the muscle was missing, it received a score of 2 ; if the complete muscle bulk was lost, it was given a score of 3. The sum of the means of the left and right muscles was the total score, ranging from zero to 6 . A total score of zero was defined as no levator defect, 1-3 as minor levator defect, and 4-6 or a unilateral score of 3 as major levator defect. Results of both scoring systems were used for comparison (Figure 6.1). The weighted kappa was used to compensate for the stepwise difference between no, minor and major levator defect. A kappa of $<0.20$ denotes poor agreement, 0.21-0.40 fair, 0.41-0.60 moderate, $0.61-0.80$ good and $0.81-1.00$ very good agreement (21).

A

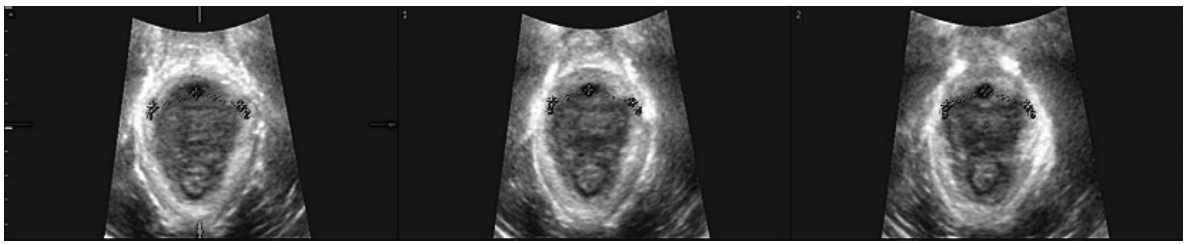
Ultrasound-score: all three slices normal MRI-score: no missing muscle on the right side (score 0 ) and the left side (score 0 ), normal

B

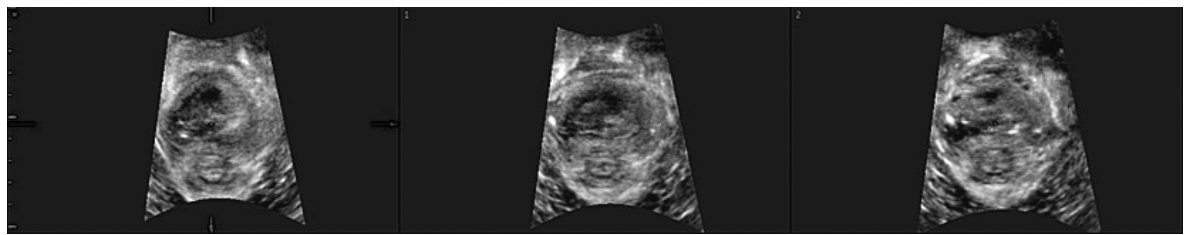

Ultrasound-score: all three slices abnormal, complete avulsion MRI-score: mean amount of missing muscle $<50 \%$ on the right side (score 1 ), and $>50 \%$ missing on the left side (score 2), total score 3, minor levator defect

C

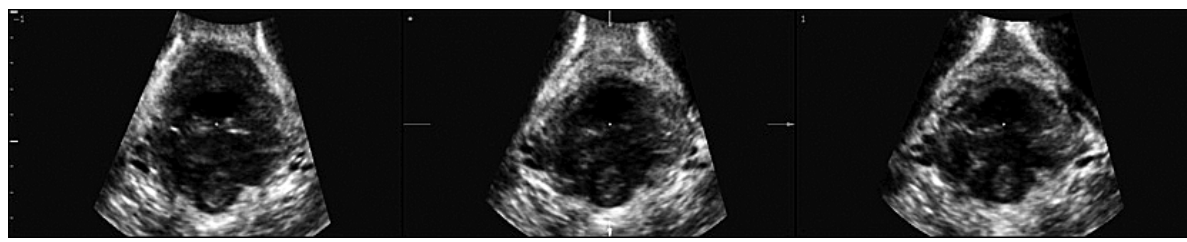

Ultrasound-score: all three slices abnormal, complete avulsion

MRI-score: mean amount of missing muscle $100 \%$ on the right side (score 3 ) and the left side (score 3), total score 6, major levator defect

Figure 6.1 Comparison of ultrasound and MRI scoring

To assess which classification system related best to clinical outcome, the receiver operating characteristic (ROC) curve and area under the curve (AUC) were compared 
for both scoring systems concerning the prediction of recurrence of cystocele after prolapse surgery. Statistical analysis was performed using statistical software package SPSS version 20.0 for Windows.

The protocol was approved by the medical ethics committees of each participating hospital. All patients who agreed to participate gave written informed consent before enrolment.

\section{Results}

Between November 2009 and April 2010, 152 participants in a follow-up study 2 years after anterior colporrhaphy underwent transperineal 3D ultrasonography (3). Patient characteristics of the initial follow-up study are shown in Table 6.1.

Table 6.1 Patient characteristics.

\begin{tabular}{lc}
\hline & Mean (range) \\
\hline Age (years) & $61.1(41-89)$ \\
BMI $\left(\mathrm{kg} / \mathrm{m}^{2)}\right.$ & $26.4(19.8-38.1)$ \\
Parity & $2.3(0-9)$ \\
Anatomical recurrence 2 years after anterior colporrhaphy $(\%)$ & $77 / 152(51)^{*}$ \\
\hline
\end{tabular}

$\mathrm{BMI}=$ body mass index ${ }^{*}$ number/ total number (\%)

In Table 6.2, MRI and ultrasound scores are compared. Comparison showed very good agreement, with a weighted kappa of $0.82(95 \% \mathrm{Cl}, 0.75,0.88)$. In one of the 41 cases with a clinically relevant defect according to MRI classification (2\%), no clinically relevant levator avulsion according to the ultrasound score was found. In 24 of the 64 cases with a clinically relevant avulsion according to ultrasound classification (38\%), no clinically relevant defect was found on MRI. This results in good agreement with a Cohen's kappa of $0.65(95 \% \mathrm{Cl}, 0.53,0.77)$ with regard to severe grade of levator defect.

Figure 6.2 shows ROC curves of the 2 classification systems and of the highest grade defects in both scoring systems for predicting recurrent cystocele after prolapse surgery. In Table 6.3 AUC of the corresponding ROC curves are summarized. There is no difference in the predictive value between classification systems. However, the AUC of the ultrasound score diagnosing the highest grade defect shows the best absolute result. 
Table 6.2 Levator defects according to ultrasound score compared with MRI score.

\begin{tabular}{lcrccc}
\hline & \multicolumn{4}{c}{ Ultrasound score Dietz et al (13) } \\
\cline { 3 - 6 } & $\begin{array}{c}\text { No } \\
\text { avulsion }\end{array}$ & $\begin{array}{c}\text { Partial } \\
\text { avulsion }\end{array}$ & $\begin{array}{c}\text { Complete } \\
\text { avulsion }\end{array}$ \\
\hline MRI score Delancey et al. (10) No defect & 29 & 5 & 0 & 34 \\
applied to ultrasound & Minor defect & 0 & 53 & 24 & 77 \\
& Major defect & 0 & 1 & 40 & 41 \\
& & 29 & 59 & 64 & 152 \\
\hline
\end{tabular}

$\mathrm{MRI}=$ magnetic resonance imaging

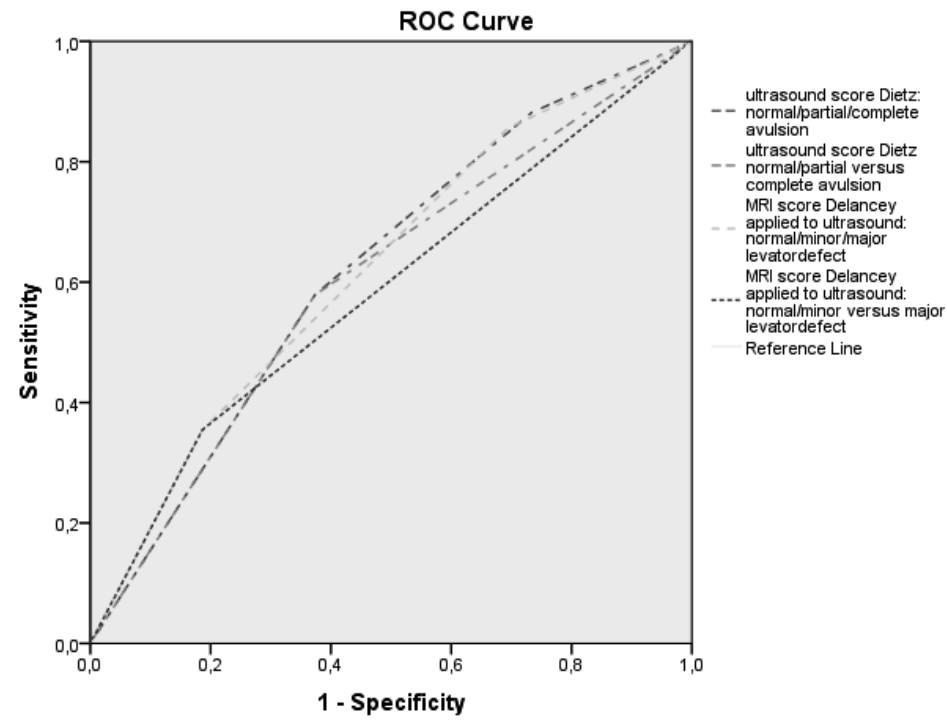

Figure 6.2 Predictive value of different scoring systems for recurrent cystocele 2 years after anterior repair.

Table 6.3 Area under the ROC curves concerning predictive value of levator defects on ultrasound for recurrent cystocele 2 years after anterior repair.

\begin{tabular}{lccc}
\hline & AUC & $\mathrm{P}$ & $95 \% \mathrm{Cl}$ \\
\hline $\begin{array}{l}\text { Ultrasound score Dietz et al (13): } \\
\text { normal / partial / complete avulsion }\end{array}$ & 0.64 & $<0.01$ & $0.55,0.72$ \\
$\begin{array}{l}\text { Ultrasound score Dietz et al (13): } \\
\text { normal / partial versus complete avulsion }\end{array}$ & 0.61 & 0.02 & $0.52,0.70$ \\
$\begin{array}{l}\text { MRI score Delancey et al. (10) applied to } \\
\text { ultrasound: normal / minor / major defect }\end{array}$ & 0.62 & 0.01 & $0.54,0.71$ \\
$\begin{array}{l}\text { MRI score Delancey et al (10) applied to } \\
\text { ultrasound: normal / minor versus major defect }\end{array}$ & 0.58 & 0.08 & $0.49,0.67$ \\
\hline
\end{tabular}

$\mathrm{ROC}=$ receiver operating characteristics; $\mathrm{AUE}=\mathrm{Area}$ under the receiver operating characteristics curve; $\mathrm{MRI}=$ magnetic resonance imaging; $\mathrm{p}=$ value for level of significance; $\mathrm{Cl}=$ Confidence interval. 


\section{Discussion}

Our results showed that there was very good agreement between the classification systems used for MRI and ultrasound in diagnosing levator defects. The agreement between the scores in describing the extent of levator damage, by identifying cases with major levator defects (cases proven to be of clinical relevance) showed good agreement with a Cohen's kappa of 0.65 . Using the ultrasound classification, more defects were categorized as complete avulsion compared with MRI classification. This study further shows similar predictive value of levator defect scoring systems with regard to cystocele recurrence after 2 years.

Zhuang et al. published a study comparing ultrasound scans with 3D MRI in 66 patients (18). In that study, ultrasound and MRI findings correlated well with each other for diagnosing levator defects. Similar to the results in our study, the authors found that with ultrasound, more complete avulsions were diagnosed, whereas with the MRI, a higher number of partial avulsions was found. The authors' explanation was that defects are best visualized on volumes obtained during a levator ani contraction, which was the case in ultrasound imaging and not in MRI. However, in our study, the same ultrasound volumes at Valsalva were used for both classification systems. Our study thus showed that this may not be the explanation for the differences between the ultrasound and MRI scores. The difference seems to result from the use of different scoring systems rather than from the imaging method itself.

One criticisms of the classification system described by Delancey et al. was that it quantifies the amount of muscle bulk missing, but not the amount of muscle present (11). The reason was that there are wide variations in muscle bulk among unaffected women. Even in young, nulliparous women, there is great variance in biometry of normal pubovisceral muscle diameter (22). The amount of missing muscle is related to the normal diameter for that particular patient in view of the diameter of the contralateral muscle or the part of the muscle sling caudal from the anorectal junction.

As there is no gold standard for diagnosing levator defects by which to validate the scoring systems, we have linked the two systems to clinical outcome. The predictive value of the scoring systems for cystocele recurrence after prolapse surgery was identical or similar. There are many risk factors for prolapse occurrence and recurrence: e.g., preoperative stage of prolapse, and family history of prolapse (3). As major levator defects are only one of the preoperative risk factors, the predictive value of major levator defects on ultrasound as a single risk factor for recurrent prolapse was limited.

MRI had been the imaging method of choice due to its superior spatial resolution capabilities and its ability to identify different pelvic-floor muscle groups $[18,23)$. MRI shows the entire levator ani muscle in both 2D and 3D displays $(24,25)$. Inter- and intraobserver reliability of pelvic-floor assessment with MRI varies in the literature $(15,26-28)$. However, in several studies, MRI is considered the reference standard 
(16). Nonetheless, MRI has not been adopted in clinical practice, the main reason being cost and access issues (22). Translabial 3D/4D ultrasound allows real-time imaging of the levator ani muscle, and inter- and intraobserver reliability shows a strong correlation for the majority of measurements $(14,20)$. Compared with MRI, 3D US imaging is non-invasive, more patient friendly, and less expensive. The ability to perform a real-time (4D) assessment of pelvic-floor structures makes ultrasound potentially superior to MRI. With real-time imaging, it is possible to control for confounders such as inadequate levator contraction or concomitant levator activation during Valsalva maneuver. The technique to acquire and interpret ultrasound data can be readily learned by the clinician as opposed to $\mathrm{MRI}$, which requires referral to a radiologist (17). As a diagnostic tool, ultrasound is more suitable for practical reasons. As a scientific tool, MRI has superior imaging qualities of detailed anatomy. Comparative studies between MRI and 3D ultrasound imaging, especially to evaluate levator defects, would enlarge our knowledge. Our study does not address the question of which imaging modality is best linked to clinical outcome; however, it shows that both scoring systems when used in ultrasound are equally linked to clinical outcome. It also shows that in a future comparative study, it will be possible to use the same scoring and classification system in MRI and ultrasound to make possible the direct comparison of outcome.

In conclusion, the comparison of the classification systems described by Dietz et al. (13) for ultrasound and Delancey et al. (10) with regard to MRI showed good to very good agreement in diagnosing levator defects on ultrasound. The predictive value of levator defects for recurrence after surgery was equal for the two scoring systems. 


\section{References}

1. Dietz HP, Simpson JM. Levator trauma is associated with pelvic organ prolapse. BJOG 2008;115: 979-984.

2. Dietz HP, Chantarasorn V, Shek KL. Levator avulsion is a risk factor for cystocele recurrence. Ultrasound Obstet Gynecol 2010;36:76-80.

3. Weemhoff M, Vergeldt TF, Notten K, Serroyen J, Kampschoer PH, Roumen FJ. Avulsion of puborectalis muscle and other risk factors for cystocele recurrence: a 2-year follow-up study. Int Urogynecol J 2012;23:65-71.

4. Svabik K, Shek KL, Dietz HP. How much does the levator hiatus have to stretch during childbirth? BJOG 2009;116:1657-1662.

5. Lien KC, Mooney B, DeLancey JO, Ashton-Miller JA. Levator ani muscle stretch induced by simulated vaginal birth. Obstet Gynecol 2004;103:31-40.

6. DeLancey JO, Kearney R, Chou Q, Speights S, Binno S. The appearance of levator ani muscle abnormalities in magnetic resonance images after vaginal delivery. Obstet Gynecol 2003;101:46-53.

7. Dietz HP, Lanzarone V. Levator trauma after vaginal delivery. Obstet Gynecol 2005;106:707-712.

8. Shek KL, Dietz HP. Intrapartum risk factors for levator trauma. BJOG 2010;117:1485-1492.

9. Shek KL, Chantarasorn V, Langer S, Phipps H, Dietz HP. Does the Epi-No Birth Trainer reduce levator trauma? A randomized controlled trial. Int Urogynecol J 2011;22:1521-1528.

10. DeLancey JO, Morgan DM, Fenner DE, et al. Comparison of levator ani muscle defects and function in women with and without pelvic organ prolapse. Obstet Gynecol 2007;109:295-302.

11. Kearney R, Miller JM, Ashton-Miller JA, DeLancey JO. Obstetric factors associated with levator ani muscle injury after vaginal birth. Obstet Gynecol 2006;107:144-149.

12. Morgan DM, Umek W, Stein T, Hsu Y, Guire K, DeLancey JO. Interrater reliability of assessing levator ani muscle defects with magnetic resonance images. Int Urogynecol J Pelvic Floor Dysfunct 2007;18: 773-778.

13. Dietz HP, Bernardo MJ, Kirby A, Shek KL. Minimal criteria for the diagnosis of avulsion of the puborectalis muscle by tomographic ultrasound. Int Urogynecol J 2011;22:699-704.

14. Dietz HP, Steensma AB. The prevalence of major abnormalities of the levator ani in urogynaecological patients. BJOG 2006;113:225-230.

15. Kruger JA, Heap SW, Murphy BA, Dietz HP. Pelvic floor function in nulliparous women using threedimensional ultrasound and magnetic resonance imaging. Obstet Gynecol 2008;111:631-638.

16. Majida M, Braekken IH, Bo K, Benth JS, Engh ME. Validation of three-dimensional perineal ultrasound and magnetic resonance imaging measurements of the pubovisceral muscle at rest. Ultrasound Obstet Gynecol 2010;35:715-722.

17. Barry C DH, Bhuta S, Lim Y, Greenland H, Muller R. MRI versus 3-dimensional ultrasound: a comparative study of levator hiatal dimensions in women with pelvic organ prolapse. Australian and New Zealand Continence Journal 2006;12:61-66.

18. Zhuang RR, Song YF, Chen ZQ, et al. Levator avulsion using a tomographic ultrasound and magnetic resonance-based model. Am J Obstet Gynecol 2011;205:232 e1-8.

19. Dietz HP. Quantification of major morphological abnormalities of the levator ani. Ultrasound Obstet Gynecol 2007;29:329-334.

20. Dietz HP, Abbu A, Shek KL. The levator-urethra gap measurement: a more objective means of determining levator avulsion? Ultrasound Obstet Gynecol 2008;32:941-945.

21. Altman DG. Practical statistics for medical research. Chapman and Hall, London, 1991.

22. Dietz HP, Shek C, Clarke B. Biometry of the pubovisceral muscle and levator hiatus by threedimensional pelvic floor ultrasound. Ultrasound Obstet Gynecol 2005;25:580-585.

23. Margulies RU, Hsu Y, Kearney R, Stein T, Umek WH, DeLancey JO. Appearance of the levator ani muscle subdivisions in magnetic resonance images. Obstet Gynecol 2006;107:1064-1069.

24. Hoyte L, Schierlitz L, Zou K, Flesh G, Fielding JR. Two and 3-dimensional MRI comparison of levator ani structure, volume, and integrity in women with stress incontinence and prolapse. Am J Obstet Gynecol 2001;185:11-19.

25. Fielding JR, Dumanli H, Schreyer AG et al. MR-based three-dimensional modeling of the normal pelvic floor in women: quantification of muscle mass. Am J Roentgenol 2000;174:657-660. 
26. Hoyte L, Brubaker L, Fielding JR et al. Measurements from image-based three dimensional pelvic floor reconstruction: a study of inter- and intraobserver reliability. J Magn Reson Imaging 2009;30:344350.

27. Hoyte L, Ye W, Brubaker L et al. Segmentations of MRI images of the female pelvic floor: a study of inter- and intra-reader reliability. J Magn Reson Imaging 2011;33:684-691.

28. Lockhart ME, Fielding JR, Richter $\mathrm{HE}$ et al. Reproducibility of dynamic MR imaging pelvic measurements: a multiinstitutional study. Radiology 2008;249:534-540. 



\section{Chapter 7 \\ General discussion}




\section{General discussion}

In view of the high prevalence of pelvic organ prolapse (POP) and the high recurrence rate after surgery for POP, there is a need for better (preoperative) analysis of patients with POP. Better knowledge of risk factors for recurrent POP and understanding of the underlying causes may result in a more individually tailored and effective treatment.

Delancey et al. published a conceptual model, the so called Lifespan Model, to help understand how pelvic floor dysfunction might result from different combinations of biologic and lifestyle factors (1) (Figure 7.1).

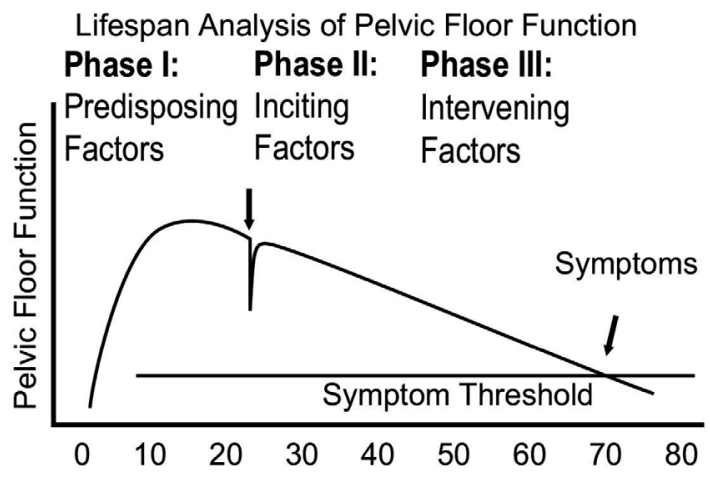

Figure 7.1 The Life span Model (Delancey 2008)

Initially, pelvic floor structure growth leads to a fully developed pelvic floor. Predisposing factors such as connective tissue features, neuronal control, and genetic factors determine the composite function. Vaginal birth affects pelvic floor function. Finally, age-related deterioration occurs until a symptom threshold is reached, where the functional reserve that was present earlier in life, is lost. Intervening factors such as obesity, constipation, chronic pulmonary disease, occupation with heavy lifting and others, influence the rate at which decline in pelvic floor function occurs (Figure 7.2). The most important inclining factor is vaginal birth, as a result from neurological and mechanical damage to the pelvic floor. Delancey et al. and Dietz et al. have described the occurrence of levator defects in vaginal delivery $(2,3)$. Both have found major levator defects to be a risk factor for developing POP $(4,5)$. Furthermore Dietz et al. found these major defects to be a risk factor for recurrence after prolapse surgery (6). 

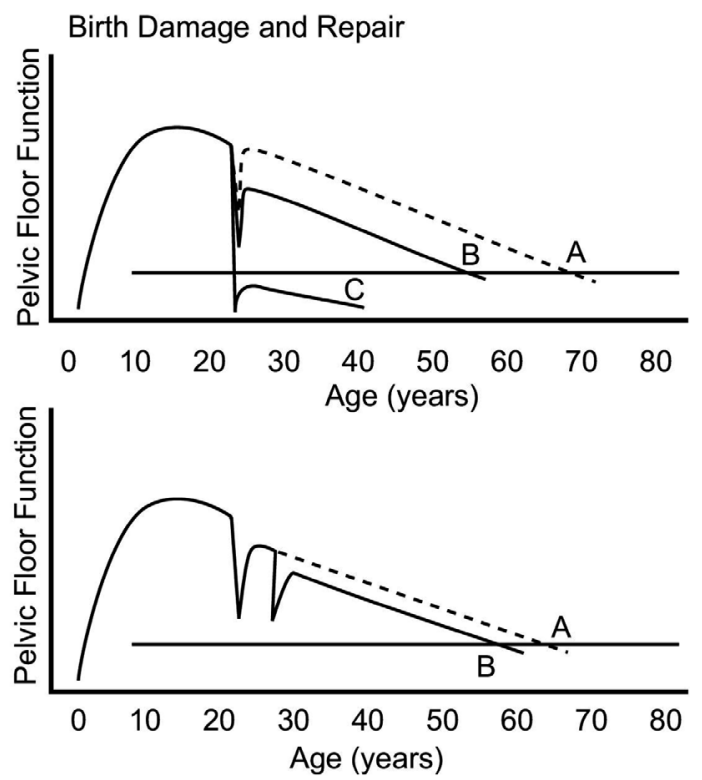

Figure 7.2 Life Span Model (Delancey 2008), Birth damage and repair as inciting factors and their influence on the rate of decline in pelvic floor function. After injury the repair can be complete and may have no influence on the pelvic floor function later in life (A). If the repair after injury is only partially the functional reserve may decrease, leading to earlier occurrence of symptoms of pelvic floor dysfunction (B). Severe injury may cause immediate problems that cannot be repaired, leading to symptoms of pelvic floor dysfunction following birth(C). A second birth may further affect the functional reserve and rate of decline.

\section{Pelvic floor ultrasound in women with anterior compartment prolapse}

Chapter 3 of this thesis illustrates the problem faced in daily practice regarding women with POP: an anatomical recurrence rate after an anterior colporrhaphy of cystoceles of $51 \%$, but a subjective recurrence rate of only $11 \%$. There is a discrepancy between anatomic findings on physical examination and the subjective feelings of the patients. It is not clear whether or which patients with anatomical recurrence will develop complaints of pelvic floor dysfunction in the future, and why one person with a cystocele POPQ stage II does and another does not have subjective feelings of a prolapse. Probably this has something to do with the underlying cause that has led to the protrusion of the vaginal wall.

Our study showed, advanced preoperative POPQ stage III and IV, a family history of POP, the surgical combination of anterior colporrhaphy with sacrospinal fixation and complete avulsion of the levator ani to be associated with recurrent cystocele after anterior colporrhaphy. Recurrence of cystocele was not associated with only a partial levator avulsion. Ultrasound and MRI studies have previously shown a relation 
between severe grade of levator ani muscle damage and POP (7-9). The development of POP was not associated with minor levator defects on MRI or partial avulsions on ultrasound, but only with severe grade levator ani muscle damage. In agreement with our findings, Dietz et al. also found complete avulsions on ultrasound to be a risk factor for recurrent cystocele after surgery (10). An important shortcoming of our study and of the study of Dietz et al., however, is the fact that pelvic floor ultrasound has been performed at the follow-up visit and not preoperatively before the anterior colporrhaphy. The timing of the ultrasound may have biased the results of both studies, because the existence of recurrent cystocele could possibly influence the ultrasonographic appearance of the levator muscle configuration in a way that more levator defects are diagnosed. Even the studies that found a relation between POP and levator avulsions have this same potential bias because the women in these studies were already having a prolapse at the time of the pelvic floor ultrasound $(4,5)$. It is thinkable that the prolapse itself interferes with the configuration of the levator hiatus on ultrasound in a way that more avulsions were diagnosed compared to women without a prolapse. The best study would be a prospective cohort study of women after delivery, after imaging their pelvic floor and diagnosing levator defects, and follow them up in time for pelvic floor dysfunction and development of POP. However the interval window yields an average of 30 years and therefore is hardly feasible.

Our study has identified, as mentioned before, four risk factors for recurrent POP. Future research is needed to confirm these findings in a prospective study. A prediction model for predicting the chance of failure of surgical treatment would be very helpful in the counseling and choosing a tailored treatment together with the patient. A patient with very high recurrence risk after surgery could then better outweigh the benefit and disadvantages of surgery in relation to conservative treatment. A prediction model would be especially helpful to better explain the pros and cons of the use of non-resorbable mesh materials to the patients, which would enhance more informed decisions regarding her personal predisposing, inciting and intervening factors. Furthermore preventive strategies could be defined for the identified risk factors.

\section{Pelvic floor ultrasound in women with posterior compartment prolapse}

Physical examination, which has always been the gold standard for the preoperative evaluation of POP, could be confirmed by additional imaging. In the posterior compartment it has been shown that only $50 \%$ of enteroceles detected on defecography were detected by physical examination in women with POP (11). An intussusception cannot be diagnosed on clinical examination. The recognition of an enterocele and intussusception pre-operatively may change the surgical approach in patients presenting with POP and evacuation difficulties. Pelvic floor ultrasound could 
give complementary information to prevent underestimation and incomplete or incorrect surgery.

In our study described in chapter 4 the diagnostic quality of perineal ultrasound for diagnosing enteroceles and intussusceptions was limited. Steensma et al. have shown promising results for the role of pelvic floor ultrasound in distinguishing a true rectocele with a fascial defect, perineal hypermobility and enteroceles on perineal ultrasound (12). Beer-Gabel et al. has reported on diagnosing enteroceles with transperineal ultrasound compared to evacuation proctography and his findings also differed significantly from our study (13). Based on the findings of Steensma et al. and Beer-Gabel et al., ultrasound would make evacuation proctography redundant in women with an abnormal ultrasound scan. In our study, however, there were many false positive findings of enteroceles on ultrasonography. The first difference in study design (between the two previous studies and ours) was the prevalence of abnormalities, with a lower prevalence in our study population. Another important difference was the fact that our study was the only study to date with more than one observer. Since there is only moderate inter observer agreement for diagnosing enteroceles on pelvic floor ultrasound, it is not likely that ultrasound performs well with regard to diagnosing enteroceles.

For diagnosing intussusceptions on perineal ultrasound, all available studies have shown the combination of a high positive likelihood ratio and a high positive predictive value. However, sensitivity of ultrasound for diagnosing intussusception is rather low, and abnormalities may be missed on ultrasound. Given the conflicting results of the available studies a strongly enough powered study, with more observers, in the target population would be needed to come to a final conclusion on the role of pelvic floor ultrasound in the diagnosis of enteroceles and intussusceptions. To recruit a sufficiently large study population, a multicenter study would be needed.

We conclude that there are at least two applications of pelvic floor ultrasound where future research is needed: levator defects and imaging in the posterior compartment. The proper diagnosis of these conditions could change clinical practice and could improve the usual care for the patient with POP.

Further research on diagnosing levator defects should focus on the clinical relevance as a risk factor for prolapse and for recurrence after prolapse surgery. Since the year 2000 many publications appeared in literature on levator defects diagnosed by pelvic floor ultrasound, but only few publications on validation of pelvic floor ultrasound have been published. Almost no comparative studies have been performed between different imaging modalities to challenge assumptions. In 2011, the first and until now only study was published on 66 patients comparing levator defects on MRI and pelvic floor ultrasound (14). Other publications on methodology focused on reproducibility instead of validation. Before the introduction of pelvic floor ultrasound in daily clinic and before use as a reference standard in research studies, no validation had taken 
place. For example, studies on palpation of levator defects and on complaints in relation to levator defects were using pelvic floor ultrasound as the reference test, ignoring the fact the reference test itself had not been validated.

Research on the role of pelvic floor ultrasound in the posterior compartment should focus on the validation of the tools and techniques used, as well as the additional value of diagnosing more rare conditions such as enterocele and intussusception prior to surgery in the posterior compartment.

\section{Ultrasound machine settings for pelvic floor ultrasound}

To perform a well designed validation study, the technical settings on the ultrasound machine should be optimized and standardized. This in order to obtain the same images in different centers and the best quality of images.

We have shown in chapter 5 for performing pelvic floor ultrasound it is essential to have an ultrasound machine with an application to reduce speckle (SRI). In the 2D mode, harmonic imaging ( $\mathrm{HI}$ ) and cross beam compound resolution imaging (CRI) will further optimize the image quality.

Dietz et al. has published a monograph on pelvic floor ultrasound, containing a chapter on the technological aspects of pelvic floor ultrasound (15). In this chapter, the software applications including SRI, HI and CRI were summed. However, there were no details given on which application to use in the 2D or 3D mode. To our knowledge, there was no other publication in literature on optimization and standardization of settings for pelvic floor ultrasound to compare our results with.

Future research is needed to find out whether our recommendations for technical settings are the most optimal for other patient populations, such as women with POP.

\section{Scorings system levator defects}

Levator defects can be detected by ultrasound and by MRI. There is little comparative research on MRI and 3D ultrasound imaging of the pelvic floor, especially to evaluate levator defects. Until now, direct comparison in studies using MRI with studies using ultrasound for diagnosing levator defects was limited due to different scoring and classification systems. It was not clear whether the cutoff between a minor and a severe grade levator defect on ultrasound was identical to the cutoff used in MRI.

We have shown in chapter 6 of this thesis that it was possible to use the scoring system as described by Delancey et al., which was primarily meant for MRI, for assessing ultrasound scans as well (16). The agreement between both scorings systems was very good. While using the ultrasound classification, more defects were categorized as complete avulsion compared to the MRI classification. Zhuang et al. in their comparative study between ultrasound and MRI in 66 subjects have likewise found that on ultrasound more complete avulsions were diagnosed, whereas with MRI a higher number of partial avulsions were found (14). The authors' explanation was that defects were best visualized on volumes that were obtained during a levator 
ani contraction, which was the case in ultrasound imaging and not in MRI. However, in our study the same ultrasound volumes assessed at rest were used for both classification systems. Our study showed the difference between rest and contraction is not the explanation for the differences between ultrasound and MRI scores. The difference seemed the result from the use of different scoring systems rather than from the imaging modalities itself.

The predictive value of both scoring systems for cystocele recurrence after prolapse surgery was comparable. There was no clinical implication of the difference in assessment of severity of levator defects. We conclude that both scoring systems can be used to describe levator defects on ultrasound. In future research when ultrasound and MRI have to be compared both imaging modalities can use the same MRI scoring system. This prevents incomparable outcomes due to the use of different scoring classifications.

\section{General conclusion}

It is remarkable how little has been done to substantiate findings in research projects on the additional value of a new diagnostic tool such as pelvic floor ultrasound. Since the year 2000 many publications appeared in literature on levator defects diagnosed by pelvic floor ultrasound, but only few publications on methodology and validation of pelvic floor ultrasound have been published. Based on this thesis we can conclude that there are at least two applications of pelvic floor ultrasound where future research is needed. The first is further research on levator avulsion as a risk factor of recurrent prolapse after surgery, as part of the development of a prediction model for recurrence after surgery. The second research-topic is on the role of pelvic floor ultrasound in the posterior compartment.

After concluding that further research on levator defects in POP was worthwhile in the first part of this thesis, we have reached consensus on the best technical settings of the ultrasound machine and on the use of the classification scoring systems with regard to levator defects in the second part of the thesis.

\section{Future research}

With respect to levator defects as a risk factor for recurrent prolapse after anterior colporrhaphy, the Dutch Organization for Health Research and Development ZonMw provided funding for a prospective trial called TRUDIL (TRanslabial Ultrasound for Dlagnosing Levator defects) (17). Primary aim of the TRUDIL is to estimate the diagnostic accuracy of translabial 3D ultrasonography of the pelvic floor as compared to MRI for diagnosing levator defects in women with POP. The secondary aim is to estimate the level of agreement between observers. Furthermore it will be studied whether levator defects are a risk factor for recurrence after POP in a prospective 
cohort. The TRUDIL has been started in 2010, inclusion has been completed and the one year follow up and data analysis is presently in its final phase. 


\section{References}

1. Delancey JO, Kane Low L, Miller JM, Patel DA, Tumbarello JA. Graphic integration of causal factors of pelvic floor disorders: An integrated lifespan model. Am J Obstet Gynecol 2008;199:610.e1-5.

2. DeLancey JO, Kearney R, Chou Q, Speights S, Binno S. The appearance of levator ani muscle abnormalities in magnetic resonance images after vaginal delivery. Obstet Gynecol 2003;101:46-53.

3. Dietz HP, Lanzarone V. Levator trauma after vaginal delivery. Obstet Gynecol 2005;106:707-712.

4. DeLancey JO, Morgan DM, Fenner DE, Kearney R, Guire K, Miller JM et al. Comparison of levator ani muscle defects and function in women with and without pelvic organ prolapse. Obstet Gynecol 2007;109:295-302.

5. Dietz HP, Simpson JM. Levator trauma is associated with pelvic organ prolapse. BJOG 2008:115: 979-84.

6. Dietz HP, Chantarasorn V, Shek K Levator avulsion is a risk factor for cystocele recurrence. Ultrasound Obstet Gynecol 2010;36:76-80.

7. DeLancey JO, Kearney R, Chou Q, Speights S, Binno S. The appearance of levator ani muscle abnormalities in magnetic resonance images after vaginal delivery. Obstet Gynecol 2003;101:46- 53.

8. Dietz HP, Simpson JM Levator trauma is associated with pelvic organ prolapse. BJOG 2008;115:979-984.

9. DeLancey JO, Morgan DM, Fenner DE, Kearney R, Guire K, Miller JM et al Comparison of levator ani muscle defects and function in women with and without pelvic organ prolapse. Obstet Gynecol 2007;109:295-302.

10. Dietz HP, Chantarasorn V, Shek KL. Levator avulsion is a risk factor for cystocele recurrence. Ultrasound Obstet Gynecol 2010;36:76-80.

11. Kelvin FM, Hale DS, Maglinte DDT, Patten BJ, Benson JT. Female pelvic organ prolapse: diagnostic contribution of dynamic cystoproctography and comparison with physical examination. AJR 1999;173:31-37.

12. Dietz HP, Steensma AB. Posterior compartment prolapse on two-dimensional and three-dimensional pelvic floor ultrasound: the distiction between true rectocele, perineal hypermobility and enterocele. Ultrasound Obstet Gynecol 2005;26:73-77.

13. Beer-Gabel M, Assoulin $Y$, Amitai M, Bardan E. A comparison of dynamic transperineal ultrasound (DTP-US) with dynamic evacuation proctography (DEP) in the diagnosis of cul de sac hernia (enterocele) in patients with evacuatory dysfunction. Int J Colorectal Dis 2008;23:513-519.

14. Zhuang RR, Song YF, Chen ZQ, Ma M, Huang HJ, Chen JH. Li YM. Levator avulsion using a tomographic ultrasound and magnetic resonance-based model. Am J Obstet Gynecol 2011;205:232 e1-8.

15. Dietz HP, Hoyte LPX, Steensma AB. Atlas of pelvic floor ultrasound. Springer-Verlag London Limited 2008 ISBN 978-1-84628-520-522.

16 Morgan DM, Umek W, Stein T, Hsu Y, Guire K, DeLancey JO. Interrater reliability of assessing levator ani muscle defects with magnetic resonance images. Int Urogynecol J Pelvic Floor Dysfunct 2007;18:773-778.

17. Notten KJ, Weemhoff M, Kluivers KB, Schweitzer KJ, Mulder F, Stoker J, Beets-Tan RG, Futterer JJ, Vliegen RF, Evers JL, Link G, Bergmans MG, Kampschöer PH, Gondrie ET, van Gestel I, van Dooren I, Dirksen C, Smits L, Bossuyt PM, Roovers JP. Protocol for Translabial 3D-Ultrasonography for diagnosing levator defects (TRUDIL): a multicentre cohort study for estimating the diagnostic accuracy of translabial 3D-ultrasonography of the pelvic floor as compared to MR imaging. BMC Women's Health 2011,11:23. 

Summary / Samenvatting 


\section{Summary}

\section{Chapter 1}

This chapter provides a general introduction on the subject of pelvic organ prolapse (POP). The definition, epidemiology, etiology, risk factors, symptoms, and surgical treatment of POP are discussed. Additional imaging of the pelvic floor may be used to confirm the evaluation as performed by clinical examination, might further elucidate possible causes of the prolapse, and could give complementary information on issues to prevent underestimation and incomplete or incorrect surgery. There is a growing number of publications in literature on the promising role of pelvic floor ultrasound, but many aspects of pelvic floor ultrasound are however still unknown and not yet standardized. This thesis explores different aspects of pelvic floor ultrasound as an additional diagnostic tool for the analysis of a patient with POP.

\section{Chapter 2}

In chapter 2 a randomized controlled trial is described in which 245 women underwent an anterior colporrhaphy because of a cystocele of at least POPQ stage II. Patients were randomly assigned to a 2- or 5-day protocol of postoperative indwelling catheterization. After removal of the catheter a residual volume after micturition of more than $200 \mathrm{Ml}$ was considered abnormal. Compared to the 5-day protocol group, in the 2-day protocol group more patients needed temporary catheter replacement [ $9 \%$ versus $28 \%$, odds ratio (OR) 4.0, 95\% confidence interval $(\mathrm{Cl}) 1.9,8.3, \mathrm{p}<0.01$ ], whereas less patients had a urinary tract infection (37\% versus $22 \%$, OR $0.5,95 \% \mathrm{Cl}$ $0.3-0.9, p=0.02$ ) and the median hospital stay was shorter. The presence of urinary tract infection was strongly associated with a higher number of temporary catheter replacements both in the 2-day protocol and the 5-day protocol group. In the 2-day protocol group the risk of temporary catheter replacement was 12 times higher in case there was a urine tract infection (OR 12.4, 95\% Cl 4.1, 37.3, $\mathrm{p}<0.01$ ).

\section{Chapter 3}

In this chapter the results are described from a prospective observational follow-up study of women after an anterior colporrhaphy because of a cystocele of at least POPQ stage II. Aim of the study was to assess the number of recurrent cystoceles 2 years after a colporrhaphy and to identify risk factors for recurrence. An important research question was whether an avulsion of the levator ani muscle is a risk factor for recurrent prolapse after surgery.

All participants of the randomized controlled trial focusing on regimen of catheterization after anterior colporrhaphy as described in chapter 2 were invited 2 years after the initial operation to participate in a follow-up study. Patients who agreed to participate were invited for a follow-up visit consisting of a validated 
questionnaire, a physical examination, and translabial 3D-ultrasonography of the pelvic floor.

156 women (64\%) agreed to a follow-up visit. The anatomical recurrence rate was 80 of 156 (51.3\%). 17 of the 156 (10.9\%) reported subjective recurrence. Risk factors for anatomical recurrence were complete avulsions of the puborectal muscle. (OR 2.4, $95 \% \mathrm{Cl} 1.3,4.7)$, advanced preoperative POPQ stage III and IV (OR 2.0, 95\% Cl 1.0, 4.1), family history of prolapse (OR $2.4,95 \% \mathrm{Cl} 1.2,4.9$ ), and sacrospinous fixation (OR 6.5, $95 \% \mathrm{Cl} 2.0,21.2)$.

\section{Chapter 4}

The study described in chapter 4 concerns the level of agreement between transperineal ultrasound and evacuation proctography for diagnosing enteroceles and intussusceptions. In a prospective observational study, 50 consecutive women who were planned to have an evacuation proctography underwent transperineal ultrasound as well. The recorded videos of the evacuation proctography were assessed by two experienced observers and the ultrasound scans were assessed by two observers experienced in pelvic floor ultrasound. A consensus meeting was held on the cases the assessors disagreed about.

For diagnosing intussusceptions a positive finding on transperineal ultrasound was predictive of an abnormal evacuation proctography (PPV 1.00, 95\% Cl $0.40,1.00$ ). Sensitivity of transperineal ultrasound was poor for intussusceptions $(0.25,95 \% \mathrm{Cl}$ $0.07,0.52)$. For diagnosing enteroceles the positive likelihood ratio was $2.10(95 \% \mathrm{Cl}$ $0.49,9.0)$ and the negative likelihood ratio $0.85(95 \% \mathrm{Cl} 0.56,1.29)$. There were many false positive findings of enteroceles on ultrasonography (PPV $0.29,95 \% \mathrm{Cl} 0.04,0.71$ ). The interobserver agreement of the two ultrasonographers, assessed as the quadratic weighted kappa, of diagnosing enteroceles was 0.44 , and of diagnosing intussusceptions was 0.23 .

We concluded that, in this study, an intussusception on ultrasound is predictive for an abnormal evacuation proctography, but ultrasound has low sensitivity for diagnosing intussusceptions. For diagnosing enteroceles the diagnostic value of transperineal ultrasound was limited as compared to evacuation proctography.

\section{Chapter 5}

In chapter 5 a research project is described with the aim to find the best ultrasound setting to optimize the quality of pelvic floor ultrasound imaging. A pilot study yielded three potential settings to be of importance: speckle reduction imaging (SRI), harmonic imaging $(\mathrm{HI})$, and cross beam compound resolution imaging (CRI). Five observers assessed 2D and 3D pelvic floor ultrasound images for quality in 5 healthy nulligravid volunteers. Eight images per volunteer were presented at random to the observers who were instructed to order the images according to perceived quality. The best quality was defined as the image in which the different structures bone, 
muscle, and blood vessel were the most recognizable and the borders between structures were the most sharp.

In the $2 \mathrm{D}$ mode the area under the curve $(A \cup C)$ in the receiver operating curve (ROC) was $0.845,0.609$, and 0.592 for $\mathrm{SRI}, \mathrm{HI}$, and $\mathrm{CRI}$, respectively. Best quality images were obtained using the combination of SRI, CRI, and HI (AUC 0.914). In the 3D mode, the AUC of the SRI alone was 0.913 , while SRI in combination with the CRI and HI yielded an AUC of 0.987.

We concluded that speckle reduction is the single most important software application for optimizing the imaging quality of pelvic floor ultrasound in both 2D and 3D mode. Adding $\mathrm{HI}$ and $\mathrm{CRI}$ slightly improved the image quality.

\section{Chapter 6}

In this chapter two different scorings methods for describing levator defects as can be diagnosed by pelvic floor ultrasound are compared. The classification as described by Dietz et al. for ultrasound and the classification as described by Delancey et al. for MRI was compared in ultrasound scans. Aim of the study was to determine whether the MRI score could be used for describing findings on pelvic floor ultrasound and thereby making it possible to compare the findings of both imaging modalities in a future comparative research project. The ultrasound images of 152 women were scored according to both scorings methods and the results were compared. On the ultrasound classification more defects were categorized as highest grade compared to the MRI classification ( $n=64(42 \%)$ versus $n=41(28 \%), p<0.01)$. The grades of the levator defects on both scoring systems showed very good agreement with a weighted kappa of $0.82(95 \% \mathrm{Cl}, 0.75,0.88)$. The predictive value of scoring systems for cystocele recurrence after prolapse surgery showed a comparable AUC of 0.63 and 0.64. We can conclude that both scoring systems can be used to describe levatordefects on ultrasound images.

\section{Chapter 7}

Chapter 7 contains a general discussion on the findings presented in this thesis. It is remarkable how little has been done to substantiate findings in research projects on the additional value of a new diagnostic tool such as pelvic floor ultrasound. Since the year 2000 many publications appeared in literature on levator defects diagnosed by pelvic floor ultrasound, but only few publications on methodology and validation of pelvic floor ultrasound have been published. On the base of this thesis we can conclude that there are at least two applications of pelvic floor ultrasound where future research is needed. The first is further research on levator avulsion as a risk factor of recurrent prolapse after surgery, as part of the development of a prediction model for recurrence after surgery. The second research-topic is on the role of pelvic floor ultrasound in the posterior compartment. 


\section{Samenvatting}

\section{Hoofdstuk 1}

Dit hoofdstuk geeft een algemene inleiding over genitale prolaps (verzakkingen). De definitie, epidemiologie, etiologie, risicofactoren, symptomen en chirurgische behandeling van verzakkingen worden beschreven. Beeldvorming van de bekkenbodem kan de diagnose zoals deze bij lichamelijk onderzoek wordt gesteld bevestigen. Het kan aanvullende informatie geven zodat een onderschatting of het missen van afwijkingen bij lichamelijk onderzoek wordt voorkomen en daarmee wordt ook onvolledig chirurgisch herstel voorkomen. Daarnaast zou beeldvorming van de bekkenbodem meer informatie kunnen verschaffen over de oorzaak van een genitale prolaps. Er is een toename van het aantal publicaties over de veelbelovende rol van echoscopie van de bekkenbodem. Vele methodologische aspecten van bekkenbodemechoscopie zijn echter nog niet onderzocht en er zijn nauwelijks validatiestudies verricht. Dit proefschrift omvat enkele onderzoeken naar verschillende aspecten van bekkenbodemechoscopie als diagnostisch instrument voor de patiënt met een genitale prolaps.

\section{Hoofdstuk 2}

In Hoofdstuk 2 wordt een gerandomiseerde studie beschreven onder 245 vrouwen die een voorwandplastiek ondergingen in verband met een cystocele van minimaal POPQ stadium II. De vrouwen werden gerandomiseerd voor een postoperatief protocol waarbij er gedurende 2 of gedurende 5 dagen een verblijfskatheter werd gegeven. $\mathrm{Na}$ verwijdering van de katheter werd een blaasresidu van meer dan $200 \mathrm{ml}$ na spontane mictie als abnormaal beschouwd. In de 2 dagen protocol groep was bij $28 \%$ van de patiënten herkatheterisatie nodig ten opzichte van $9 \%$ in de 5 dagen protocol groep (OR 4.0, 95\% Cl 1.9, 8.3, p<0.01). Daartegenover hadden de patiënten in de 2 dagen protocol groep minder urineweginfecties (37\% versus $22 \%$, OR $0.595 \% \mathrm{Cl} 0.3,0.9$, $\mathrm{p}=0.02$ ) en was de mediane opnameduur in het ziekenhuis korter in vergelijking met de patiënten uit de 5 dagen protocol groep. Verder was opvallend dat in beide groepen de aanwezigheid van een urineweginfectie sterk geassocieerd was met de noodzaak tot herkatheterisatie. In de 2 dagen protocol groep was deze associatie zo sterk dat de kans op herkatheterisatie in aanwezigheid van een urineweginfectie 12 maal zo hoog was als zonder een urineweginfectie (OR 12.4, 95\% $\mathrm{Cl} 4.1,37.3, \mathrm{p}<0.01$ ).

\section{Hoofdstuk 3}

In hoofdstuk 3 worden de resultaten besproken van een prospectief observationeel follow-up onderzoek van de vrouwen die hadden deelgenomen aan het gerandomiseerde onderzoek ter vergelijking van 2 postoperatieve protocollen van katheterisatie (hoofdstuk 2). De vrouwen ondergingen allen een voorwandplastiek in 
verband met een cystocele van minimaal POPQ stadium II. Doel van het onderzoek was het vaststellen van het aantal recidieven 2 jaar na een voorwandplastiek en het identificeren van risicofactoren voor het ontwikkelen van een recidief. Een belangrijke vraag hierbij was of de aanwezigheid van een levatoravulsie een risicofactor is voor het ontwikkelen van een recidief na een voorwandplastiek.

Alle vrouwen die hadden deelgenomen aan het gerandomiseerde onderzoek betreffende het postoperatieve katheterisatie protocol werden 2 jaar na de voorwandplastiek benaderd voor deelname aan een follow-up onderzoek. De deelnemers vulden een vragenlijst in, ondergingen een lichamelijk onderzoek en een transperineale bekkenbodemecho.

Er waren 156 vrouwen die akkoord gingen met deelname. Er werd bij 80 van de 156 vrouwen een anatomisch recidief vastgesteld van een cystocele van minimaal POPQ stadium II (51.3\%), 17 van de 156 vrouwen hadden subjectief klachten van een recidief verzakking (10.9\%).

Risicofactoren voor een anatomisch recidief waren een complete avulsie van de musculus levator ani (OR 2.4; $95 \% \mathrm{Cl} 1.3,4.7)$, hoog preoperatief POPQ stadium III en IV (OR 2.0, 95\%1.0, 4.1), een positieve familieanamnese voor prolaps (OR $2.4,95 \% \mathrm{CI}$ $1.2,4.9$ ) en de combinatie van een voorwandplastiek met een sacrospinale fixatie (OR $6.5,95 \% \mathrm{Cl} 2.0,21.2)$.

\section{Hoofdstuk 4}

Het onderzoek dat in hoofdstuk 4 wordt beschreven betreft de mate van overeenstemming tussen bekkenbodemechoscopie en het defecogram voor het diagnosticeren van enteroceles en intussuscepties. In een prospectief observationeel onderzoek ondergingen 50 vrouwen die gepland waren voor het ondergaan van een defecogram in verband met fecale incontinentie of ernstige obstipatie ook een bekkenbodemecho De video's van het defecogram werden door 2 chirurgen met ervaring in het beoordelen van defecogrammen beoordeeld. De echobeelden werden door 2 gynaecologen met ervaring in bekkenbodemechoscopie beoordeeld. Alle beoordelaars waren geblindeerd voor klinische data. Wanneer er geen overeenstemming was tussen beide beoordelaars vond een consensusbespreking plaats.

Voor de diagnostiek van intussuscepties bleek een positieve bevinding op een bekkenbodemecho zeer voorspellend voor een intussusceptie op het defecogram (PPV 1.00, 95\% Cl 0.40, 1.00). De sensitiviteit van de bekkenbodemecho was echter laag voor intussuscepties $(0.25,95 \% \mathrm{Cl} 0.07,0.52)$. Voor de diagnostiek van enteroceles had bekkenbodemechoscopie een positieve likelihood ratio van 2.10 (95\% $\mathrm{Cl} 0.49,9.0)$ en een negatieve likelihood ratio van 0.85 (95\% $\mathrm{Cl} 0.56,1.29)$. Er waren veel vals positieve enteroceles bij bekkenbodemechoscopie (PPV 0.29, 95\% Cl 0.04, $0.71)$. 
De inter-observer overeenstemming tussen de echoscopisten voor het vaststellen van intussuscepties toonde een gewogen kappa van 0.23 . Voor het vaststellen van enteroceles was de gewogen kappa 0.44. Concluderend kunnen we stellen dat in dit observationele onderzoek een intussusceptie bij bekkenbodemechoscopie voorspellend was voor intussusceptie op het defecogram, maar echoscopie had verder een lage sensitiviteit voor het aantonen van intussuscepties. Voor de diagnostiek van enteroceles was de diagnostische waarde van de bekkenbodemechoscopie beperkt in vergelijking tot het defecogram.

\section{Hoofdstuk 5}

In hoofdstuk 5 wordt een onderzoek beschreven waarvan het doel was de instelling te identificeren op het echoapparaat die de beste kwaliteit beelden oplevert bij het doen van bekkenbodemechoscopie. In een pilot onderzoek bleken er 3 echoinstellingen te zijn die potentieel relevant waren bij het maken van de beste kwaliteit beelden: de speckle reduction imaging (SRI), de harmonic imaging $(\mathrm{HI})$ en de cross beam compound resolution imaging (CRI). Vijf onderzoekers beoordeelden 2D en 3D beelden op kwaliteit die waren gemaakt bij 5 gezonde vrijwilligers die nog nooit zwanger waren geweest. De instellingen van de SRI, HI en CRI (aan/uit) werden gecombineerd in de 2D en de 3D modus. Dit leidde tot $82 \mathrm{D}$ en 8 3D beelden per proefpersoon, die door de beoordelaars in een rangorde van kwaliteit werden geplaatst

De beste kwaliteit werd omschreven als die echobeelden waarbij de verschillende structuren als bot, spier en bloedvaten het meest herkenbaar waren en de overgangen tussen deze verschillende structuren het scherpst zichtbaar.

In de 2D modus was de oppervlakte onder de curve (AUC) van de receiver operating curve (ROC), als maat voor de beste kwaliteit beelden $0.845,0.609$ en 0.592 voor SRI, $\mathrm{HI}$ en respectievelijk CRI, De beste kwaliteit beelden werden verkregen bij de combinatie van SRI, CRI en HI (AUC 0.914). In de 3D modus was de AUC van de SRI alleen 0.913, terwijl de SRI in combinatie met de CRI en HI een AUC van 0.987 had.

Concluderend kan gesteld worden dat speckle reductie in de 2D en in de 3D modus de meest belangrijke software applicatie is om de echobeelden van de bekkenbodem te optimaliseren. Het aanzetten van de $\mathrm{HI}$ en de CRI kan de kwaliteit daarnaast nog iets verbeteren.

\section{Hoofdstuk 6}

In dit hoofdstuk worden 2 methoden vergeleken voor het beschrijven en scoren van levatordefecten zoals deze bij bekkenbodemechoscopie kunnen worden vastgesteld. De eerste methode betreft de voor bekkenbodemechoscopie gebruikelijke methode zoals beschreven door Dietz et al. De tweede methode is door Delancey et al. beschreven voor het beoordelen van MRI scans. Op dit moment is er in de literatuur slechts één vergelijkende studie tussen echo en MRI wat betreft levatordefecten. Om 
een vergelijking mogelijk te maken in toekomstige onderzoeksprojecten tussen echo en MRI wordt beoordeeld of het mogelijk is om bij echo dezelfde methode van het kwantificeren van beschadiging te gebruiken als bij MRI wordt gebruikt. In dit onderzoek worden echobeelden van 152 vrouwen beoordeeld en de mate van beschadiging van de bekkenbodemspier gekwantificeerd volgens beide scoringsmethoden. De resultaten hiervan worden vergeleken.

Bij de echoscore worden in vergelijking met de MRI classificatie meer levatordefecten als compleet gecategoriseerd. [ $n=64(42 \%)$ versus $n=41 \quad(28 \%), p<0.01]$. De overeenstemming tussen de 2 systemen voor het graderen van de levatordefecten is zeer goed (gewogen kappa $0.82,95 \% \mathrm{Cl} 0.75,0.88$ ). De voorspellende waarde van beide scoringsmethoden voor recidief cystoceles na prolapschirurgie toont een vergelijkbare oppervlakte onder de curve (AUC 0.63 versus 0.64). We kunnen concluderen dat beide scoringsmethoden kunnen worden gebruikt voor het beschrijven van levatordefecten op echobeelden.

\section{Hoofdstuk 7}

Hoofdstuk 7 betreft een algemene discussie waarin de resultaten uit de verschillende onderzoeken binnen een groter kader worden geplaatst. Het is opmerkelijk hoe weinig methodologisch onderzoek is verricht naar de echoscopie als diagnostisch instrument. Sinds het jaar 2000 is er een toenemend aantal publicaties over toepassingen van echoscopie van de bekkenbodem. Validering van echoscopie van de bekkenbodem voor het vaststellen van levatordefecten heeft niet of nauwelijks plaatsgevonden, terwijl er al wel grote klinische betekenis aan de uitkomsten van echoscopie wordt toegekend. Op basis van dit proefschrift kunnen we concluderen dat er 2 toepassingsgebieden zijn van echoscopie van de bekkenbodem waar verder toekomstig onderzoek zinvol is. Het eerste betreft onderzoek naar levatordefecten en de rol hiervan bij het ontstaan van prolaps en het ontwikkelen van recidieven na prolapschirurgie. Het tweede betreft onderzoek naar de rol van echoscopie van de bekkenbodem in het achterste compartiment. 
List of publications 


\section{List of publications}

\section{Journal papers}

Vergeldt TF, Weemhoff M, Notten KJ, Kessels AG, Kluivers KB.. Comparison of two scoring systems for diagnosing levator ani muscle damage. Int Urogynecol J 2013 (Epub ahead of print).

Weemhoff M, Kluivers KB, Govaert B, Evers JLH, Kessels AGH, Baeten CG. Transperineal ultrasound compared to evacuation proctography for diagnosing enteroceles and intussusceptions. Int J Colorectal Dis 2013;28:359-363.

Weemhoff M, Vergeldt TFM, Notten K, Serroyen J, Kampschoer PHNM, Roumen FJME. Avulsion of puborectalis muscle and other risk factors for cystocele recurrence: a 2 year follow-up study. Int Urogynecol J 2012;23:65-71.

Notten KJ, Weemhoff M, Kluivers KB, Schweitzer KJ, Mulder F, Stoker J, Beets-Tan RG, Futterer JJ, Vliegen RF, Evers JL, Link G, Bergmans MG, Kampschöer PH, Gondrie ET, van Gestel I, van Dooren I, Dirksen C, Smits L, Bossuyt PM, Roovers JP. Protocol for Translabial 3D-Ultrasonography for diagnosing levator defects (TRUDIL): a multicentre cohort study for estimating the diagnostic accuracy of translabial 3D-ultrasonography of the pelvic floor as compared to MR imaging. BMC Women's Health 2011,11:23.

Weemhoff M, Wassen MMLH, Korsten L, Serroyen J, Kampschöer PHNM, Roumen FJME. Postoperative catheterization after anterior colporrhaphy: 2 days versus 5 days. A multicentre randomized controlled trial. Int Urogynecol J 2011;22:477-483.

Weemhoff M, Shek KL, Dietz HP. Effects of age on levator function and morphometry of the levator hiatus in women with pelvic floor disorders. Int Urogynecol J 2010;21:1137-1142.

Weemhoff M, Nijhuis JG, Hollanders JMG, Jager W. The pregnant patient with acute liver disease. Ned Tijdschr Geneesk 2002;146:2513-2514.

Weemhoff M, Nijhuis JG, Koek GH, Hollanders JMG en Peeters LLH. Acute fatty liver of pregnancy, the possible role of the foetus in causing the disease. Ned Tijdschr Perinat Geneesk 2002;2:44-49.

Weemhoff M, van Meir CA, Walther FJ, Twaalfhoven FC, van Roosmalen J. Delayed birth of the second child in multiple gestation. Ned Tijdschr Geneesk 2001;145:13771380 . 
Weemhoff M, Twaalfhoven FC, Haans LC, van Weelde BJ, Idenburg,FJ, van Roosmalen J. Pain in the symphyseal region after parturition: possibly osteomyelitis. Ned Tijdschr Geneesk 2001;145:424-427.

Weemhoff M, van Beek JJ. Follow up of complaints and recurrence after laparoscopic surgery of benign adnexal tumours. Gynaecol Endoscopy 2000;9: 91-94.

\section{Book chapters}

Weemhoff M, Dewilde D, Hamelynck. Praktische Huisartsgeneeskunde (PHG), Praktische gynaecologie. Definitieve anticonceptie. Bohn Stafleu van Loghum 2013 (in press).

Weemhoff M, Willekes C, Vierhout ME. Sfincterletsel. Obstetrische interventies ISBN 9789035230996, Elsevier 2010.

Dorr PJ, Keizer M, Weemhoff M, Khouw VM. Anatomie. Obstetrische interventies ISBN 9789035230996, Elsevier 2010.

\section{International conference presentations}

Notten KJB, Weemhoff M, Roovers JPWR, Schweitzer K, Futterer J, Stoker J, Mulder F, Beets-Tan R, Vliegen R, Kluivers KB. The TRUDIL study : TRanslabial Ultrasound for Diagnosing Levatordefects compared to MR imaging. Oral presentation IUGA 2013, Dublin.

Notten KJB, Essers B, Weemhoff M, Rutten AGH, Donner J, Gestel van I, Kruitwagen, RFPM., Roovers, JPWR, Dirksen C. Do patients prefer mesh or anterior colporrhapy for primary correction of cystocele: A labeled discrete choice experiment. Oral presentation IUGA 2013, Dublin.

Notten KJB, Weemhoff M, Kluivers KB, Schweitzer KJ, Mulder F, Stoker J, Beets-Tan RGH, Futterer JJ, Vliegen RFA, Smits LJM, Roovers JWR. Diagnosing levator defects on 3D transperineal ultrasound compared to MR imaging . Oral presentation ISUOG 2012, Kopenhagen.

Vergeldt TF, Weemhoff M, Notten KJ, Kessels AG, Kluivers KB. Comparison of two scoring systems for diagnosing levator ani muscle damage. Oral presentation ISUOG 2012, Kopenhagen. (price for best presentation in section urogynecology)

Gerver J, Notten KJB, Link G, Gestel I, Winden LAAP, Kessels AGH, Weemhoff M. Learning Curve of 3D/4D translabial ultrasound for diagnosing levator ani defects. Oral presentation ISUOG 2012, Kopenhagen. 
Weemhoff M, Wassen MMLH, Korsten L, Serroyen J, Kampschöer PHNM, Roumen FJME. Postoperative Urinary Bladder Catheterisation after Anterior Colporrhaphy. Oral presentation IUGA 2009, Como.

Weemhoff M, Kluivers KB. Inter-Observer Reliability of Translabial 3DUltrasonography for Diagnosing Levator Defects. Oral presentation IUGA 2009, Como.

Weemhoff M, Shek KL, Dietz HP. Effect of age on levator function and morphometry. Oral presentation ICS 2008, Caïro.

Weemhoff M. Pelvic Floor Ultrasound. Oral presentation IAMU 2008, Arhus.

Weemhoff M, van Beek JJ. Evaluation of recurrence and complaints after laparoscopic surgery of benign adnexal tumours. Oral presentation ESGE 1998, Lausanne. (price for best junior researcher)

\section{International conference abstracts}

Weemhoff M, Notten K, Kluivers KB, Hoeks AP, Evers JHG Kessels AG, Hoogland HJ. Optimizing the imaging quality of pelvic floor ultrasound. Abstract IUGA 2013, Dublin.

Weemhoff M, G. Bremer, Kampschoer PHNM, Roumen FJME. TOT versus TVT, long term follow up regarding success and complications. Abstract IUGA 2007, Cancun.

Kluivers KB, Mol BWJ, Bongers MY, Bremer GL, Weemhoff M, Withagen MIJ, Brölman HAM, Vierhout ME. Urinary incontinence in randomised laparoscopic and abdominal hysterectomy patients. Abstract IUGA 2006, Athene. 

Curriculum Vitae 


\section{Curriculum Vitae}

Mirjam Weemhoff werd op 8 november 1970 geboren in Foumban, Kameroen. In 1990 behaalde zij haar atheneumdiploma aan het Augustinus College te Groningen en het jaar daarna startte zij haar studie Geneeskunde aan de Rijksuniversiteit Groningen. Zij deed een onderzoeksstage op de afdeling Obstetrie en Gynaecologie van het St. Elisabeth Hospitaal te Curaçao in samenwerking met de GGD aldaar. Tijdens haar studie werkte zij als onderzoeksassistent bij het Bureau Onderzoek Onderwijs Groningen (BOOG). Vervolgens volgde zij haar co-schappen in het Medisch Centrum Leeuwarden en haar keuze co-schap op de afdeling Obstetrie en Gynaecologie van het Sophia ziekenhuis te Zwolle. Na het cum laude behalen van haar artsexamen in 1998 volgde zij haar grote liefde André Postema naar het westen van het land en werkte als arts assistent niet in opleiding op de afdeling Obstetrie en Gynaecologie in het Bronovo ziekenhuis te Den Haag en vervolgens in het Antoniushove ziekenhuis te Leidschendam. Nadat zij was aangenomen voor de opleiding Obstetrie en Gynaecologie in het cluster Maastricht werkte zij nog een jaar als arts assistent niet in opleiding op de afdeling Interne Geneeskunde en Oncologie in het Antoniushove ziekenhuis te Leidschendam. In 2000 verhuisde zij met haar partner naar Maastricht en startte met de opleiding tot gynaecoloog. Deze begon in het academisch ziekenhuis Maastricht (opleider: prof. dr. J.L.H. Evers), waarna in 2003 een detachering van tien maanden in het Maasland ziekenhuis te Sittard volgde, om tenslotte vanaf 2004 de laatste twee jaren van de opleiding in het Atrium Medisch Centrum te Heerlen, Brunssum en Kerkrade (opleider: dr. F.J.M.E. Roumen) af te ronden. In 2002 werd zij moeder van zoon Jort en in 2005 werd dochter Roos geboren. In 2006 begon zij met het onderzoek dat de basis van dit proefschrift is geworden. In dit jaar leerde zij de eerste beginselen van de bekkenbodemechoscopie van dr. Anneke Steensma, werkzaam in het Erasmus Medisch Centrum te Rotterdam. Sinds januari 2007 werkt zij als gynaecoloog in het Maastricht Universitair Medisch Centrum binnen de pijler gynaecologie, met het aandachtsgebied urogynaecologie. Na een onderzoeksstage in 2008 bij prof. dr. H.P. Dietz te Sydney, Australië, heeft haar onderzoek naar bekkenbodemechoscopie zich verder ontwikkeld. Het onderzoek valt onder het Maastrichtse onderzoeksinstituut GROW, School for Oncology and Developmental Biology. Mirjam Weemhoff is in 2011 geregistreerd als subspecialist in de urogynaecologie. 

Dankwoord 
Mijn dankwoord is kort. Omdat het niet volledig kan zijn, beperk ik mij tot de kern.

\section{Bedankt!}

Hans en Roy, voor jullie steun en vertrouwen

Kirsten, voor alles wat we samen hebben meegemaakt

Rixt en Iris, voor jullie gezelschap op deze dag en ook de afgelopen jaren Kim, voor al het sparren over onze echo's Henk en Fons, jullie hielpen me iedere keer weer verder Collega's, voor de samenwerking en alle gesprekjes tussendoor Vriendinnen, voor alle hardlooprondes, wandelingen en etentjes Margreet, Jeannette en jullie gezinnen, voor de fijne momenten samen Rochus en Corry, omdat jullie er altijd zijn Jort en Roos, voor elke morgen vrolijkheid en betekenis André, voor ons samen leven 
